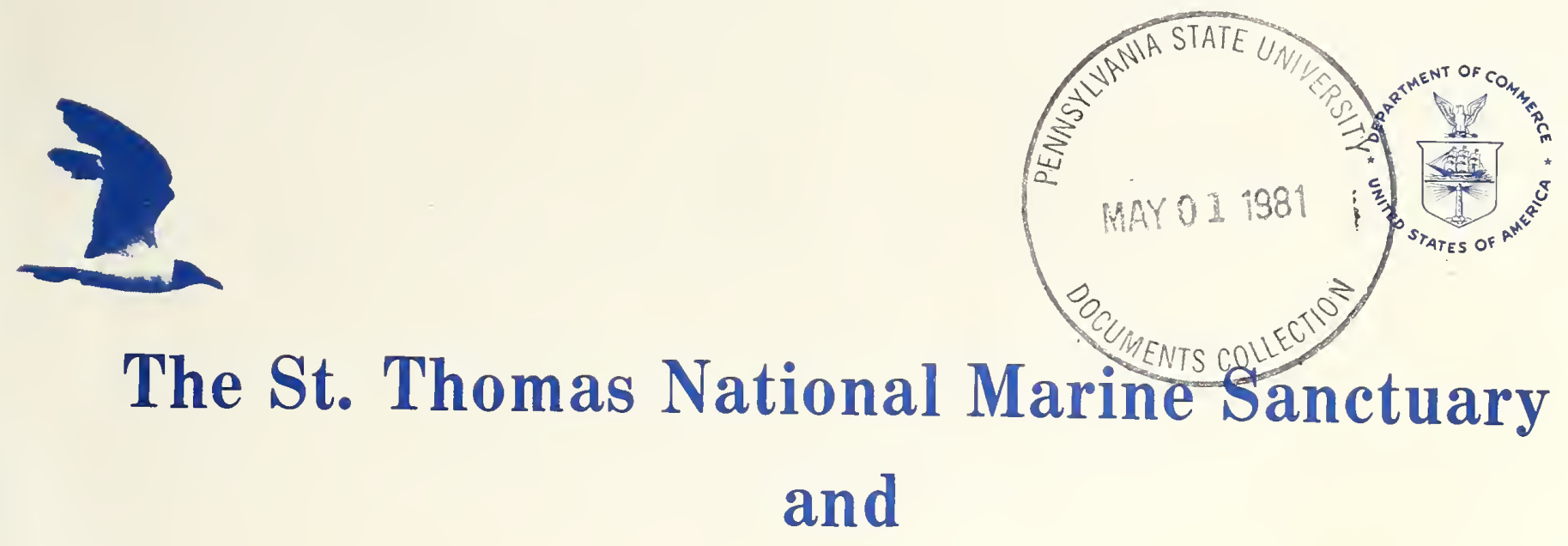

\title{
Draft Environmental Impact Statement
}
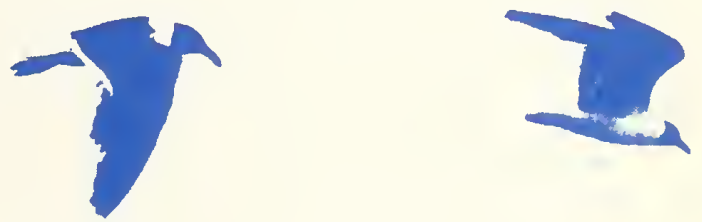

WASHINGTON, D.C. APRIL 1981

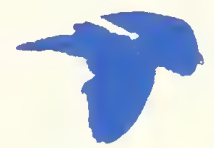

U.S. DEPARTMENT OF COMMERCE National Oceanic and Atmospheric Administration/Office of Coastal Zone Management

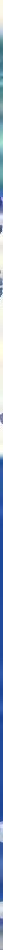





\author{
United States \\ Department of Commerce \\ Draft Environmental Impact Statement
}

Apri 1981

PROPOSED ST. THOMAS NATIONAL MARINE SANCTUARY

Prepared by:

Office of Coastal Zone Management

National Oceanic and Atmospheric

Administration

3300 Whitehaven Street, N.W.

Washington, D.C. 20235

and

Virgin Islands Government

Department of Conservation and

Cultural Affairs

St. Thomas, Virgin Islands 


\section{Digitized by the Internet Archive in 2012 with funding from LYRASIS Members and Sloan Foundation}


DESIGNATION: Draft Environmental Impact Statement

Title: $\quad$ Proposed St. Thomas National Marine Sanctuary

Abstract: The National Oceanic and Atmospheric Administration (NOAA) proposes the designation of the waters immediately off southeast St. Thomas, United States Virgin Islands, as a marine sanctuary. The proposed sanctuary consists of 9.27 square nautical miles of waters under territorial jurisdiction.

The designation of a marine sanctuary would establish a program of comprehensive management, including research, assessment, monitoring, resource interpretive programs, coordination and regulation. The preferred alternative includes sanctuary management goals and objectives which will serve as a framework around which sanctuary activities will be structured.

The Virgin Islands would promulgate specific regulations pursuant to the Virgin Islands Coastal Zone Management Act of 1978 (12VIC $\$ 901$ ) which would apply only within the sanctuary boundary. NOAA will also adopt these regulations as its sanctuary regulations. The proposed regulations prohibit the taking or damaging of any living natural resource; permit traditional fishing methods except at designated dive areas; prohibit disturbance of cultural resources; prohibit anchoring in a matter damaging to coral; prohibits the discharge of substances except cooling waters from vessels, fish, fish parts or chumming materials, and discharges from marine sanitation devices. In addition, the proposed regulations limit alteration of the seabed to the area outside of the Mangrove Lagoon and only allow such activites in the public interest.

Alternatives to the proposed action include the no action or status quo alternative, and modification of the sanctuary boundaries.

LEAD AGENCY: U. S. Department of Commerce National Oceanic and Atmospheric Administration Office of Coastal Zone Management

CONTACT: Dr. Nancy Foster, Deputy Director Sanctuary Programs Office OCZM

3300 Whitehaven Street, NW Washington, D.C. 20235 



\begin{tabular}{|c|c|}
\hline Chapter One & Introduction and Summary \\
\hline Chapter Two & Purpose and Need \\
\hline \multirow[t]{6}{*}{ Chapter Three } & $\begin{array}{l}\text { Analysis of Alternatives Including the } \\
\text { Proposed Action }\end{array}$ \\
\hline & A. Introduction \\
\hline & B. No Action Alternative \\
\hline & C. The Preferred Aternative \\
\hline & D. Impacts of the Preferred Alternative \\
\hline & $\begin{array}{l}\text { E. Aternative Three: Establishment of a Smaller } \\
\text { Marine Sanctuary }\end{array}$ \\
\hline \multirow[t]{6}{*}{ Chapter Four } & Description of the Affected Environment \\
\hline & I. Natural Environment \\
\hline & $\begin{array}{l}\text { A. Geology } \\
\text { B. Climate and Current } \\
\text { C. Offshore Islands and Cays } \\
\text { D. Biological Zones }\end{array}$ \\
\hline & II. Endangered Species \\
\hline & III. Cultural and Historic Resources \\
\hline & IV. Socio-Economic Setting \\
\hline \multicolumn{2}{|c|}{ List of Preparers } \\
\hline \multicolumn{2}{|l|}{ Bibliography } \\
\hline \multicolumn{2}{|c|}{ APPENDIX A: Draft Designation and Regulations } \\
\hline APPENDIX B: & $\begin{array}{l}\text { alysis of Existing Federal and Territorial } \\
\text { atutes }\end{array}$ \\
\hline
\end{tabular}


FIGURE 1: Site Location of the Proposed St. Thomas

Marine Sanctuary

FIGURE 2: Boundary Alternatives

FIGURE 3: Water Current Observations 31

FIGURE 4: Benthic Communities 34

FIGURE 5: Historic and Cultural Resources 39

FIGURE 6: Reporting Areas Used to Assess the Geographic 44 Distribution of Recreational Boating and Fishing Activity 
TABLE 1: Offshore Islands and Cays in Waters of the Proposed Sanctuary

TABLE 2: Summary of Documented Shipwrecks in the Proposed St. Thomas Marine Sanctuary

TABLE 3: Dive Sites Within the Proposed Sanctuary Frequency of Trips/Dive Visits

TABLE 4: Annual Recreational and Commercial Fishery Landings

TABLE 5: Use of the Major St. Thomas Anchorages

TABLE 6: Charter Boat Activity in 1978 and 1979 in the Virgin Islands

TABLE 7: Existing V.I. Commercial Fishing Regulations and Proposed V.I. Fishery Advisory Committee Recommended Changes

App. B 
APC Area of Particular Concern

CFA Commercial Fisheries Act

CFMC Caribbean Fisheries Management Council

CWA Clean Water Act

CZMA Coastal Zone Management Act

DCCA Department of Conservation and Cultural Affairs

DEIS Draft Environmental Impact Statement

ESA Endangered Species Act

FAC Fishery Advisory Committee

FCMA Fishery Conservation and Management Act

FEIS Final Environmental Impact Statememt

MMPA Marine Mammal Protection Act

MPRSA Marine Protection, Research and Sanctuaries Act

MSAB Marine Sanctuary Advisory Board

NMSP National Marine Sanctuary Program

NOAA National Oceanic and Atmospheric Administration

OCZM Office of Coastal Zone Management

VICZMA Virgin Islands Coastal Zone Management Act

VICZMP Virgin Islands Coastal Zone Management Program

WPCA Water Pollution Control Act 


\section{Background}

The Marine Protection, Research, and Sanctuaries Act of 1972 (MPRSA), 16 U.S.C. 1431-1434, authorizes the Secretary of Commerce, after consultation with appropriate Federal agencies and the affected State, and with Presidential approval, to designate ocean areas having distinctive conservation, recreational, ecological, or aesthetic values as marine sanctuaries.

In 1978 the Virgin Islands Department of Conservation and Cultural Affairs (DCCA) initiated the development of a Marine Parks and Reserves System for the Virgin Islands under the auspices of the emerging Territorial Park System. After a number of potential sites were inventoried and analyzed, DCCA decided to establish the first marine park off the eastern and southeastern coast of St. Thomas. A public hearing held in 1978 to discuss this proposal revealed that many user groups had serious reservations about the desirability of the Marine Park and Reserve System being proposed. In early 1979, while DCCA was reformulating its marine park plan, several sites off St. Thomas were assessed by DCCA for suitability as possible national marine sanctuaries. In April 1979, the Commissioner of DCCA appointed a Marine Sanctuary Advisory Board (MSAB) to provide public advice on the selection of a sanctuary site and the development of a management plan.

In May 1979, DCCA recommended an area off southeast St. Thomas to be designated as a national marine sanctuary (see Figures 1 and 2 ). As part of the scoping process, in July 1979 the National Oceanic and Atmospheric Administration (NOAA) and DCCA distributed an Issue Paper exploring the possibility of marine sanctuary designation at the site. On August 8, 1979, NOAA and DCCA held a public workshop to obtain comments on the Issue Paper. The proposal received support from local fishermen, divers, conservation groups, and the Virgin Islands Government. No opposition was voiced regarding the proposed sanctuary.

Following the workshop, DCCA and NOAA under a cooperative agreement began preparation of a Draft Environmental Impact Statement (DEIS). On November 8, 1979, NOAA printed a Notice of Intent to Prepare an Environmental Impact Statement in the Federal Register and held a scoping meeting in Washington. NOAA and DCCA have gathered and analyzed information and consulted with Federal agencies, territorial government agencies, the Caribbean Fishery Management Council (CFMC), and local interest groups and individuals.

Following the publication of the DEIS, NOAA and DCCA will hold joint public hearings to receive comments on the proposal to designate the St. Thomas National Marine Sanctuary. Written comments will be accepted for sixty (60) days. If NOAA AND DCCA decide to proceed, a Final Environmental Impact Statement will be issued and will include the final proposal. At that time the Secretary of Commerce will initiate final consultation with other Federal agencies and the CFMC. Finally, if NOAA decides to proceed with the proposal, Presidential approval of the designation must be obtained. 


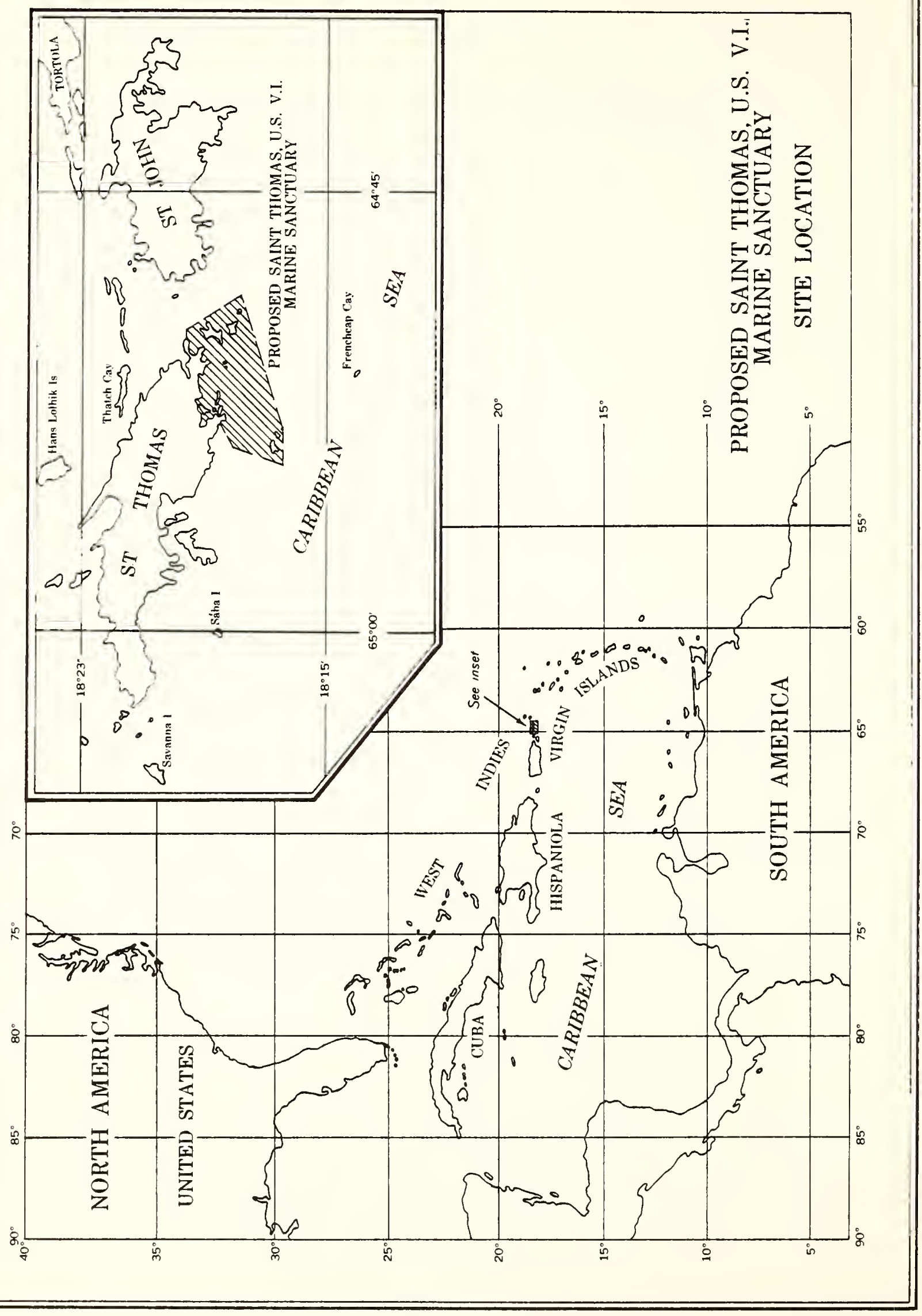




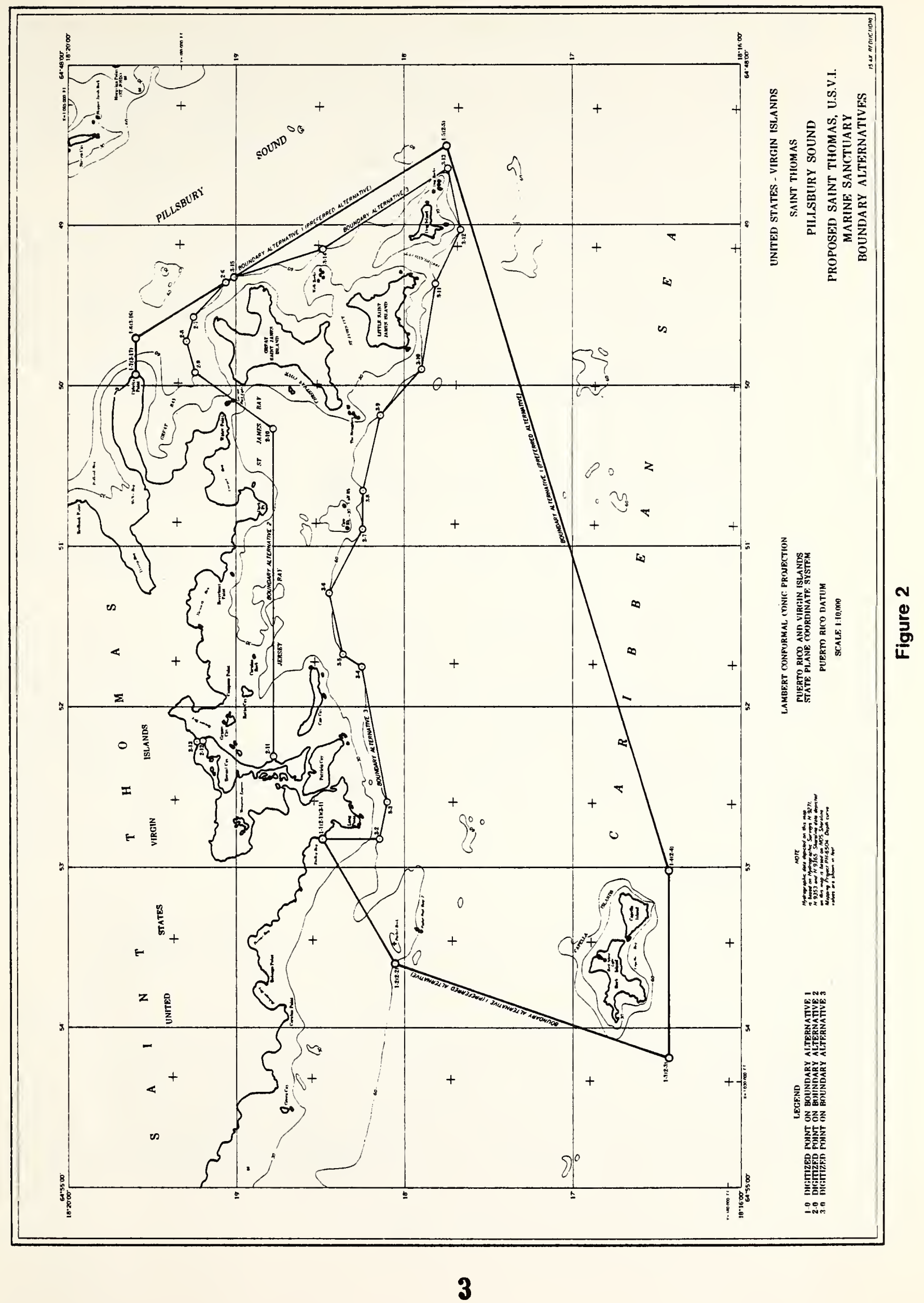




\section{I. National Marine Sanctuary Program}

The National Marine Sanctuary Program (NMSP) provides comprehensive management of marine ecosystems for the long-term protection of natural resources and the enjoyment and benefit of society. The program is responsible for establishing and maintaining a national system of marine sanctuaries for the purpose of protecting or restoring special marine areas for their conservation, recreational, ecological, or aesthetic values. The program focuses attention on sites of national interest and concern.

The following goals present a framework for the national sanctuary system:

- Enhance resource protection through implementation of a comprehensive long-term management plan tailored to the specific resources;

- Promote and coordinate research to expand scientific knowledge of significant marine resources and improve management decision making;

- Enhance public awareness, understanding, and wise use of the marine environment through public educational, interpretive, and recreational programs; and

- Provide for maximum compatible use of special marine areas and ecosystems.

\section{Proposed St. Thomas National Marine Sanctuary}

The Office of Coastal Zone Management (OCZM), which is responsible for the Marine Sanctuary Program within NOAA, proposes the designation of a marine sanctuary in waters off southeast St. Thomas, U.S. V.I., under Title III of the Marine Protection, Research, and Sanctuaries Act of 1972. Sanctuary designation will provide long-term protection through a program of comprehensive management which provides for public use, scientific research, assessment, monitoring, surveillance and enforcement and resource interpretation including public education.

\section{A. Proposed Boundary}

The proposed Sanctuary consists of 9.27 square nautical miles of Virgin Islands' territorial waters immediately southeast of St. Thomas. The coordinates of the points that define the proposed sanctuary boundary are as follows (Figure 2 ):

Beginning at the shoreline of Stalley Bay at Latitude $18^{\circ} 18^{\prime} 29^{\prime \prime}$ Longitude $64^{\circ} 52^{\prime} 49^{\prime \prime}$ to a point southwest of Packet Rock at Latitude $18^{\circ} 18^{\prime} 03^{\prime \prime}$ Longitude $64^{\circ} 53^{\prime} 36^{\prime \prime}$, to a point southwest of Buck Is 1 and at Latidude $18^{\circ} 16^{\prime} 26^{\prime \prime}$, Longitude $64^{\circ} 54^{\prime} 11^{\prime \prime}$ thence northeast to a point off Dog Rocks at Latitude $18^{\circ} 17^{\prime} 45^{\prime \prime}$ Longitude $64^{\circ} 48^{\prime} 30^{\prime \prime}$, north to a point off Cabrita Point at Latitude $18^{\circ} 19^{\prime} 36^{\prime}$ Longitude $64^{\circ} 49^{\prime} 42^{\prime \prime}$ then to the shoreline of Cabrita Point at Latitude $18^{\circ} 19^{\prime} 36^{\prime \prime}$ Longitude $64^{\circ} 49^{\prime} 56^{\prime \prime}$. 
The proposal area comprises the entire Mangrove Lagoon, Jersey and Cowpet Bays, the waters surrounding Great and Little St. James, Dog Island, Buck Island and Capella Island. The preferred boundary alternative encompasses diverse tropical marine ecosystems, including numerous habitat types and a variety of marine species. The comprehensive management approach provided by sanctuary designation would assist maintenance and enhancement of longterm productivity of the entire system.

With the exception of the Benner Bay area, where extensive marina development has al ready occurred, the remainder of the proposal area is pristine. The Mangrove Lagoon area, which comprises Bovoni Cay, Cas Cay, and Patricia Cay, is the most extensive red mangrove system remaining in the Virgin Islands. The area is a major nursery for several species of reef fish and the spiny lobster (Panulirus argus). The remainder of the proposal area is dominated by fine sandy areas with transitional marine meadows of algae (Halimeda) and turtle grass (Thalassia testudineum) and 15 different biotic associations of calcareous algal plains and zones of rock and rubble and open ocean waters. A series of shallow fore reefs, deep reefs, and back reefs have been identified within the proposal area. Elkhorn coral (Acropora palmata) dominates the shallow fore reef along with a variety of other species of corals including massive formations of star corals (Siderastrea and Montastrea) and brain coral (Diplora). The reef communities surrounding the offshore islands and cays are variable and include several species of sponges and soft coral assemblages in the shallower waters.

St. Thomas' economy is based on tourism, and most tourist attractions are water-related. The waters of the proposal area are the locus for as much as 20 percent of all Virgin Islands boating activity, including considerable use of the area for both private diving and commercial diving tours. The resources are such that the area provides spectacular coral reef diving experiences, most notably, the coral cave formations at Cow and Calf Rocks, and the coral reefs at Buck Island, Capella Island and Nazareth Bay. Several shipwrecks are located within the waters of the proposed Sanctuary. The most notable is the Royal Mail steamship, HMS WYE, which sank on the south shore of Buck Island. Much of the rigging, ribs, sides and engine can still be seen. Other wrecks include the recently relocated World War I freighter, the Cortensar Senior, now located in the West Bay, Buck Island; an unidentified wreck at whelk Rocks; and a Caribbean trading schooner.

B. PROPOSED MANAGEMENT

1. GOALS AND OBJECTIVES

Management of the St. Thomas National Marine Sanctuary will focus on the attainment of several goals and objectives (Chapter Three, Analysis of Alternatives Including the Preferred Alternative). The goals and objectives for the St. Thomas Sanctuary reflect (1) use capacity of the proposed Sanctuary; (2) anticipated needs and demands to be placed on the resources; (3) potential threats to resource quality; (4) the need to conserve and protect Sanctuary resources; (5) the need to encourage both management-related and general research; and (6) the need to increase, through interpretive programs public awareness of the proposed St. Thomas National Marine Sanctuary as a nationally valuable resource. The goals and objectives provide the foundation for management 
policies in the proposed Sanctuary and promote conservation, coordinated research, public education and information exchange. (See Chapter Three for a complete description of the management plan.) All management planning and decision making will be conducted within the framework of this plan and be directed towards fulfilling the program goals and objectives. Objectives for each goal will represent short-term, measurable steps towards achieving the long-term, unquantifiable goals and will be similar to those listed below:

Goal 1: To conserve Sanctuary resources in a manner compatible with the MSP goals and objectives in order to maintain, protect, and enhance the quality of the area's biological, aesthetic, and cultural resources.

Tentative objectives include development of specific activities and mechanisms designed to maintain the overall integrity of the area. Priorities would be given to upgrading the Mangrove Lagoon area and monitoring fishery resources. Coordination of all agencies with managerial responsibilities in the area would be provided.

Goal 2: To encourage scientific research within the Sanctuary focused on improvement of decision making and increasing the level cf knowledge of the area's natural system.

Tentative objectives would include activities to encourage and cooperate with interested parties in research and marine science education and to provide a mechanism to exchange and disseminate research data.

Goal 3: To enhance national and 1ocal awareness of the significance of the marine resources within the proposed Sanctuary in order to encourge wise use of these resources.

Tentative objectives would include establishing a Sanctuary Information Center in addition to developing and promoting marine education and resource interpretative programs focused on ecological relationships for school curricula and the general public.

Goal 4: To optimize compatible public uses within the Sanctuary in a manner which respects traditional uses of the area while conserving the resources.

Tentative objectives would include establishment of a Marine Sanctuary Advisory Board, designating dive areas and other special management areas, and managing fishery resources.

\section{SANCTUARY MANAGEMENT ACTIVITIES}

In order to provide an efficient system for management of the proposed St. Thomas National Marine Sanctuary, a cooperative arrangement between NOAA and the Virgin Islands Government is planned. The Virgin Islands Department of Conservation and Cultural Affairs will be the onsite manager and will be charged with daily management of the Sanctuary. Management will include such activities as: 
Surveillance and enforcement are an integral part of the management and protection of the proposed Sanctuary. DCCA's Bureau of Enforcement will be charged with the responsibility of enforcement operations. The management plan will describe in detail the surveillance and enforcement system necessary to meet the goals and objectives of the proposed Sanctuary and will indicate how the natural and cultural resources, existing and potential human activities, and environmental constraints will be considered in surveillance and enforcement of the Sanctuary regulations.

\section{Environmental Analysis and Planning}

Research, resource assessment, and monitoring are basic to effective management. Research in the proposal area has been ongoing; however, it has not been focused on overall management of the area nor is there an established clearinghouse for research specific to the proposal area. Detailed quantitative and qualitative data will be gathered on the area's cultural and marine resources and will form a sound data base for management strategies. Where appropriate, based on knowledge of the resources, their significance, their carrying capacity and the extent of public uses, specific management activities will be recommended. Provision for periodic monitoring will be made to ensure that future management requirements are obtained.

Consideration is being given for selecting areas for dive sites. Areas currently under consideration for dive areas include: Great Bay, the Cortensar Senior, the southwest point of Little St. James, Packet Rock, and Nazareth Bay. Cultural resources will be surveyed and assessed.

\section{Public Education and Information Exchange}

Public education and information exchange are mechanisms that assure public appreciation and participation in sanctuary management. Public education programs will be developed to encourage recreation in the sanctuary that is compatible with resource conservation and wise management. Interpretive programs will be developed to promote public understanding and appreciation for the resources of the sanctuary. The plan will provide a range of management strategies for interpretive programs. A clearinghouse will be established for all research conducted in the proposal area and a mechanism for information exchange will be developed. In addition, a Marine Sanctuary Advisory Board (MSAB), with membership from user groups directly impacted by actions in the sanctuary will be established to advise DCCA with respect to sanctuary management.

\section{PROPOSED SANCTUARY REGULATIONS}

The preferred alternative proposes a Sanctuary with rules and regulations developed and promulgated by NOAA and the Virgin Islands. The Virgin Islands will implement the regulations under the Virgin Island Coastal Zone Management Act (VICZMA). This approach relies on the Virgin Islands Coastal Zone Management Program (VICZMP) for permitting activities and establishes a mechanism whereby NOAA will monitor the Virgin Islands' implementation of sanctuary regulations. It also provides a procedure that allows for NOAA to intervene if the Virgin Islands fails to enforce the sanctuary regulations and provide adequate management. 
The following activities would be subject to regulations (see Appendix A).

(1) Removing, breaking or otherwise harming coral, other bottom formations or plants, except as incidental to other fishing operations.

(2) Operations of vessels except fishing vessels, and anchoring by all vessels.

(3) Construction on, dredging of, or altering of the seabed.

(4) Discharging or depositing certain substances or objects.

(5) Using poisons, electric charges or explosives.

(6) All activities, including fishing, along designated underwater trails.

(7) Removing or harming cultural and historical resources.

(8) Removing or damaging navigation aids, markers, and fishing traps or gear.

(9) Activities affecting or likely to affect marine mammals, turtles, or other endangered species.

C. The Status Quo

A variety of Federal and Territorial statutes apply to activities occurring within the proposal area. One alternative to marine sanctuary designation is the no action alternative. Existing Federal statutes (Endangered Species Act, and Fisheries Conservation and Management Act) and Territorial statutes (Virgin Islands Coastal Zone Management Act, Commercial Fisheries Act, Water Pollution Control Act) would continue to provide the legal framework for protecting the area's resources under the no action alternative.

However, despite the adequacy of the legal authorities, additional funding is necessary to provide comprehensive management to the area. In addition, under the status quo alternative no consideration is envisioned for protection of specific resources such as coral, marine meadows, or shipwrecks without the additional management and support impetus of the sanctuary.

The marine sanctuary designation would augment existing legal authority and funding capabilities in order to provide a comprehensive mechanism for longterm management. This designation would also serve to protect the integrity of the area and those coordinated activities occurring within it.

\section{Other Alternatives to the Proposed Action}

NOAA and DCCA reviewed two smaller boundary alternatives for the proposed Sanctuary (see Figure 2). One alternative to the preferred boundary option (Boundary Alternative 2) would include much of the same area as the preferred alternative but would exclude areas such as Benner Bay, Cowpet Bay, and the intertidal areas from Cowpet Point to Deck Point. This option would focus on 
the Mangrove Lagoon and open water areas. Another boundary alternative considered (Boundary Alternative 3) would include only the Mangrove Lagoon and Benner Bay complex; dive areas located at Packet Rocks, Buck and Capel1a Islands would not be included. NOAA and DCCA jointly determined that these boundary alternatives would not assure representation of all the diverse resources in the area. Sanctuary regulations would be difficult to enforce in an area of this size and violators would have sufficient time to escape. Furthermore, sanctuary goals and objectives could not be adequately implemented because the entire ecological system would not be protected.

An alternative sanctuary proposal eliminated from consideration is the establishment of a marine sanctuary without substantial Virgin Islands involvement. The entire proposal area is within territorial waters and subject to the jurisdiction of the Government of the Virgin Islands. DCCA and the V.I. Government would not support a sanctuary in territorial waters without substantial territorial government participation. Since the Act provides the Governor with the right to prevent designation of a sanctuary in territorial waters, further consideration of this alternative would not be fruitful. 
The Office of Coastal Zone Management (OCZM) of the National Oceanic and Atmospheric Administration (NOAA) and the Virgin Islands Government, Department of Conservation and Cultural Affairs (DCCA), have identified an area consisting of approximately 9.27 square nautical miles within the Virgin Islands territorial waters off southeastern St. Thomas, U.S. Virgin Islands to be a marine area of national significance that is deserving of marine sanctuary designation. In terms of ecological, cultural, recreational, and aesthetic importance, the site is significant from both a local and national perspective. The waters off southeast St. Thomas contain the most significant stand of mangroves in the Virgin Islands; extensive coral reef communities, coral caves, and several shipwrecks that are important recreational dive sites. The area also supports juvenile and adult conch, lobster, numerous fish habitats, plus nesting and feeding areas for endangered turtle and fish species. Given the distinguishing nature of the resources and proximity to St. Thomas, the area is particularly inviting to public users.

The goals of the proposed St. Thomas National Marine Sanctuary are:

- To conserve sanctuary resources in a manner compatible with the National Marine Sanctuary Program goals and objectives in order to maintain, protect and enhance the quality of the area's biological, aesthetic, and cultural resources.

$\circ$

To encourage scientific research within the Sanctuary that is focused on management-related questions and directed toward enhancement of knowledge of the area's natural systems.

$\circ$

To enhance national and local awareness of the significance of the marine resources within the proposed sanctuary; to encourage wise use of these resources; and to promote understanding of the role of the National Marine Sanctuary Program in marine conservation.

The diverse, but inter-related ecosystems of the area are delicately balanced. The coral reefs are extremely fragile and the Mangrove Lagoon area is currently under severe stress. Increasing pressures on these unique natural and cultural resources from boaters, fishermen, divers and other users coupled with the absence of a well coordinated, protective management framework, demonstrates the need for marine sanctuary designation.

Without sanctuary designation the entire proposal area will not receive comprehensive and coordinated management attention. Presently, the Virgin Islands Coastal Zone Management Program is developing regulations and a management plan for one fifth of the proposal area (the Mangrove Lagoon/Benner Bay complex) as an Area of Particular Concern (APC). However, the APC does not include the shipwrecks, coral reef formations, rock outcroppings and endangered turtle nesting areas which also require additional management protection. 
It is highly unlikely that the Virgin Islands would be able to provide the necessary funding to adequately enforce regulations and to protect the overall integrity of the proposal area. In addition, funds would not be allocated to design and conduct research or to develop educational and interpretative programs as part of a management program for the area. The present deterioration of the Mangrove Lagoon complex will not be reversed under the status quo.

Marine sanctuary designation will provide a comprehensive management mechanism to insure long-term protection of the area and together with the existing Virgin Islands Coastal Zone Management Program will provide for balanced use of the resources, well defined research and educational programs, and an enforcement mechanism to protect and preserve the recreational, ecological, and aesthetic values that make this area so unique.

OCZM, therefore, proposes to designate an area immediately southeast of St. Thomas as a National Marine Sanctuary under Title III of the Marine Protection, Research, and Sanctuaries Act of 1972. 
NOAA proposes to designate coastal waters off southeast St. Thomas as a marine sanctuary in order to provide for management and long-term protection of an ecosystem that is rich in habitat diversity and recreational value.

This designation will also serve to promote scientific understanding, public appreciation, and wise use of the area's resources. Various management, boundary, and regulatory alternatives have been considered in the evaluation of the proposed action.

This chapter presents analyses of the three viable alternatives, a no action (status quo) alternative, the proposed action (a marine sanctuary with management responsibility shared by NOAA and the Virgin Islands), and a similar cooperative sanctuary with a smaller boundary.

B. No Action Alternative: Rely on the Status Quo

The proposed sanctuary would be located off southeast St. Thomas, U.S. Virgin Islands, in waters under territorial jurisdiction. A variety of Federal and territorial laws, management programs and regulations apply to activities taking place in the general area. An alternative to the proposed action, the no action (status quo) alternative, is to rely on existing programs to provide management while relying on the existing regulatory system to control damaging activities. Under this alternative, no sanctuary would be designated. The following discussion briefly summarizes existing laws and programs and analyses their impacts.

\section{RELEVANT VIRGIN ISLANDS AND FEDERAL STATUTES}

\section{General Resource Management}

Under the Virgin Islands Coastal Zone Management Act, (VICZMA) development activities in the entire Virgin Islands' Coastal Zone, including the area under consideration as a marine sanctuary are subject to a permit review to ensure consistency with resource protection policies established by this Act. However, these policies are relatively broad and further regulations are needed to provide additional definition. Under the VICZMA, the focus of rulemaking is special area management, including regulation of established Areas of Particular Concern $(A P C)$. The Virgin Islands would promulgate such regulations for the $1 / 5$ of the proposed sanctuary that is included within the Benner Bay/Mangrove Lagoon APC, but the remainder of the area would not be subject to special management regulations. Regulations to protect and manage specific resources such as coral, marine meadows, or shipwrecks would not be promulgated without additional funds and the impetus of the Sanctuary. Therefore, their protection would continue to depend upon the issuance of permits based on the broad policies and goals of the VICZMA. A Harbor and Water Use Study is pending, but will not address management of resources, or act as an overall water use plan. It is specifically limited to existing near shore anchorages and is designed to assist the territory in collection of fees for the mooring of vessels. The VICZMA and the other relevant authorities including current enforcement procedures summarized in this section, are discussed in more detail in Appendix $B$. 
Federal and territorial statutes that control the discharges of wastes and waste water into the proposed sanctuary are adequate for insuring satisfactory water quality. Title I of the Marine Protection, Research and Sanctuaries Act, and the Virgin Islands Solid and Hazardous Waste Management Acts provide sufficient regulation of disposal of hazardous wastes. Discharges from point sources are covered by the Virgin Islands Water Pollution Control Act (WPCA). Under the WPCA, the waters of the proposed sanctuary are designated class "B" which are coastal waters intended for marine life and primary contact recreation, such as swimming. Disposal of vessel waste is regulated by the Federal Clean Water Act and enforced by the Coast Guard.

\section{Fishing}

Fishery resources are managed and regulated primarily by the Virgin Islands Commercial Fishing Act (CFA). The Caribbean Fishery Management Council (CFMC) and the Virgin Islands are coordinating regulations for fishery resources and enforcement (01sen, 1980, personal communication). The spiny lobster, mollusk and shallow water reef fish Fishery Management Plans being developed by the CFMC will address the protection and management of those resources. The Virgin Islands has agreed to revise its fishing regulations under the Virgin Islands CFA to implement the CFMC regulations.

Regulations under the CFA will provide management for the fishery resource that is consistent with proposed goals for the Sanctuary. Currently, the CFA specifies size limits of fish traps and mandates that they be partially constructed of "biodegradable" material. The Act also specifies regulations governing the taking of lobster. These regulations are aimed at conserving this resource by restricting the taking of immature and female lobsters. Proposed changes in the CFA regulations will provide additional protection and conservation measures for fishing resources that are consistent with anticipated FMPS.

\section{Endangered Species and Marine Mammals}

The Federal Endangered Species Act (ESA) and Marine Mammal Protection Act (MMPA) provide specific protection from the "harming" or "taking" of all species of marine mammals and listed endangered species. In addition, for such listed species, the ESA authorizes the designation of critical habitat areas. Such a designation, however, provides protection from only Federal or Federally funded or licensed actions. It would not protect critical habitats from actions by the territorial government or private individuals and there is no authority under the MMPA to protect localized marine habitats of exceptional importance.

\section{Impacts of the Status Quo}

Despite the authority of the Virgin Islands government to promulgate protective regulations, long-term protection for the site cannot be assured under the status quo alternative. As discussed in Chapter IV, recreational and commercial fishing and boating, and recreational diving are important activities occurring within the proposed sanctuary waters and increases in these activities are anticipated. More than 26,400 diver visits were made to the proposal area in 1979. Approximately 44 percent of the 
St. Thomas recreational boating fleet are located in sanctuary waters. Overcrowding can be expected as carrying capacity is reached. In addition, approximately 57 of the 161 St. Thomas fishermen use sanctuary waters. Under the status quo alternative a long-term comprehensive management scheme would not be implemented that address these activities and their anticipated future increases. Changes in political administrations and philosophies could result in a change in status for the area and a lessening of resource protection. As an example, the status of an APC could be changed or regulations significantly altered. Analysis indicates that in light of present and anticipated future use, the diversity of resources within the area warrants additional long-term protection, national attention, and focus in terms of comprehensive management beyond that provided by the present institutional structure.

As discussed in Chapter II, and in more detail in Chapter IV, the proposal area is a complex ecosystem containing valuable marine and cultural resources. It is also an area subject to substantial and increasing recreational use. Human activities that either singularly or in combination may place stress on the resources include: anchoring, tampering with or removing historical and cultural resources, fishing, seabed alteration and construction activities. Given the unique resources, their particular vulnerability due to increasing human pressures, and the complex nature of information and management requirements, assurance of long-term preservation of the area requires: (a) a comprehensive management approach that will monitor, assess and act on information about the cumulative effects of human uses; (b) funding to ensure all necessary requirements of the area are met, (c) a mechanism to coordinate and encourage research that will lead to effective management decisions; (d) efforts to enhance public awareness of the significance and the need for wise use of the resources in the area.

It is unlikely that substantial progress in these areas will be made under the status quo. For example, many needed management activities would not likely be undertaken. Such activities include habitat restoration projects for the Mangrove Lagoon; designation of dive areas; design and implementation of a systematic monitoring program to track ecological conditions and fluctuations in population levels; and specialized study and monitoring efforts focused on the potential use of mooring buoys.

In addition, under the status quo a coordinated educational and interpretive program focused on the specific Sanctuary area would not be implemented. Consequently, user guides to the area and public awareness and educational information would not be developed. In conclusion, despite the adequacy of existing legal authority to protect the area, the lack of funding for comprehensive management could lead to inadequate long-term protection. By augmenting existing statues and programs, NOAA can bolster this framework and build longterm protection and management into a significant site worthy of national attention.

C. The Preferred Alternative: The St. Thomas National Marine Sanctuary

NOAA proposes to designate the waters off southeast St. Thomas as a marine sanctuary to better assure the long-term protection of an ecosystem that is rich in habitat diversity and recreational value. The precise boundaries are: 
Beginning at the shoreline of Stalley Bay at Latitude $18^{\circ} 18^{\prime} 29^{\prime \prime}$ Longitude $64^{\circ} 52^{\prime} 49^{\prime \prime}$ to a point southwest of Packet Rock at Latitude $18^{\circ} 18^{\prime} 03^{\prime \prime}$ Longitude $64^{\circ} 53^{\prime} 36^{\prime \prime}$, to a point southwest of Buck Island at Latitude $18^{\circ} 16^{\prime} 26^{\prime \prime}$ Longitude $64^{\circ} 54^{\prime} 11^{\prime \prime}$, thence northeast to a point off Dog Rocks at Latitude $18^{\circ} 17^{\prime} 45^{\prime \prime}$ Longitude $64^{\circ} 48^{\prime} 30^{\prime \prime}$, north to a point off Cabrita Point at Latitude $18^{\circ} 19^{\prime} 36^{\prime \prime}$ Longitude $64^{\circ} 49^{\prime} 42^{\prime \prime}$, then to the shoreline of Cabrita Point at Latitude $18^{\circ} 19^{\prime} 36^{\prime \prime}$ Longitude 64 $49^{\prime} 56^{\prime \prime}$.

\section{Sanctuary Administration}

The proposal would establish a national marine sanctuary administered in partnership between NOAA and the Virgin Islands. The Draft Designation Document (Appendix A), which serves as a constitution for the Sanctuary, sets forth the elements of this relationship. It establishes a series of checks and balances which ensure protection of the national interest in this important area and at the same time allows the Virgin Islands government adequate flexibility for controlling it's own waters.

The basic regulations for the Sanctuary will be the special management regulations promulgated by the Virgin Islands, pursuant to its Coastal Zone Management Act (12VIC\$901) to ensure specific protection of al1 the resources throughout the Sanctuary. NOAA will adopt these regulations as its Sanctuary regulations but will not issue additional regulations unless it is to control an activity over which the Virgin Islands has no authority. Neither party can change the regulations without the consent of the other.

The Virgin Islands will have the primary enforcement responsibility and can elect to prosecute any violation under its law or turn the matter over to NOAA for prosecution in order to take advantage of the simplified civil penalty procedure established under the Marine Protection, Research and Sanctuaries Act. NOAA will monitor implementation and could assert enforcement authority in the event that there was a significant failure by the Virgin Islands to do so.

The Department of Conservation and Cultural Affairs (DCCA) would serve as on-site manager for the Sanctuary. DCCA is the environmental protection arm of the Virgin Islands government and administers territorial environmental 1 aws (See Appendix B Federal and Territorial Authority).

\section{St. Thomas National Marine Sanctuary Management Plan}

The National Marine Sanctuary Program provides long-term comprehensive management for special marine areas and focuses on protection; resource interpretation/public education; research/assessment aimed at improving marine resource management decisions; and encouraging maximum public use consistent with resource protection.

The first step in effectively addressing the resource issues within a marine sanctuary is the preparation of a formal Management Plan (MP). The Plan will address administration, surveillance/enforcement, research and assessment, public education/interpretation and visitor use. It will propose actions and programs to be implemented within a specific timeframe, provide the rationale for such actions, and relate them to other activities in the sanctuary and its vicinity. 
The heart of the Management Plan is comprised of goals and objectives for the proposed Sanctuary. They will provide a framework around which management activities will be structured. Mechanisms for conserving resources and integrating sound public uses into broader national marine sanctuary program purposes will be elaborated. Objectives for each goal will represent short-term quantified steps towards achieving the long-term goals.

\section{a. Goals and Objectives for Sanctuary Management}

The goals and objectives identified for the proposed St. Thomas National Marine Sanctuary are responsive to (1) the resource use capacity of the proposal area; (2) anticipated needs and demands to be placed on the resources; (3) potential threats to resource quality; (4) the need to conserve and protect sanctuary resources; (5) the desire to encourage both management-related and generic research; and (6) the desire to enhance, through interpretive program efforts, public awareness of the significance of the marine resources within the proposed sanctuary and to convey information on their wise use.

GOAL 1: To conserve Sanctuary resources in a manner compatible with the National Marine Sanctuary Program goals and objectives in order to maintain, protect and enhance the quality of the area's biological, esthetic, and cultural resources.

\section{Objectives}

- Emphasize reliance on existing Virgin Islands and Federal authorities.

- Identify and implement an enforcement and surveillance system to protect sanctuary resources.

- Enhance fishery resources through activities such as habitat restoration and mariculture projects; and

- Establish a coordinating mechanism to insure cooperation among all agencies with management responsibilities within the Sanctuary.

GOAL 2: To encourage scientific research within the Sanctuary that focuses on both improvement of management decision making and increasing the level of knowledge of the area's natural systems.

\section{Objectives}

- Systematically identify and synthesize existing data useful in characterizing the Sanctuary. A clearinghouse will be established to disseminate and exchange Sanctuary research data.

- Design a long-term research and assessment plan focused on information gaps and management needs; establish short-term priorities.

- Establish competitive funding mechanisms encouraging a wide range of scientific expertise to focus attention on ecological interrelationships within the Sanctuary. 
GOAL 3: To enhance national and local awareness of the significance of the marine resources within the proposed Sanctuary, to encourage wise use of these resources; and to promote understanding of the role of the National Marine Sanctuary Program in marine conservation.

\section{Objectives}

- Establish a Sanctuary Information Center to introduce the public directly to the beauty and significance of the Sanctuary resources as a national asset through interpretive programs. The Center will, in accordance with the Management Plan, provide interpretation of the Sanctuary resources to the public.

- Develop materials such as educational packages for public school curricula and for adult education programs, to increase public knowledge of the marine resources within the Sanctuary.

- Develop appropriate educational tools, such as brochures, slides, and films, to effectively communicate the significance of the sanctuary resources to the public.

GOAL 4: To optimize compatible public uses within the sanctuary in a manner which respects traditional resource uses and conserves the values for which the Sanctuary was established.

\section{Objectives}

- Provide advice to the onsite manager on matters relating to Sanctuary public use. This will be accomplished through the existing Marine Sanctuary Advisory Board consisting of representatives from various user groups.

Designate dive areas and other special management zones.

- Manage fishery resources for the benefit of all users.

In order to provide an efficient administrative mechanism for the achievement of the above objectives and for day-to-day management of the proposed St. Thomas National Marine Sanctuary, the following basic strategies are proposed. The management priorities will include provisions for enforcing and administering the proposed Sanctuary and for research and assessment.

\section{b. Onsite Manager}

Virgin Islands-Federal cooperation will form the basis for Sanctuary management. Under a cooperative agreement with NOAA, the Virgin Island's DCCA will serve as onsite manager, and will have the responsibility for enforcement and surveillance activities within the proposed Sanctuary. The Virgin Islands will be responsible for administering the Sanctuary and providing reports including, but not limited to the following items: 
- environmental analysis;

- visitor use and resource capacity studies, user-related impacts, and such other information as necessary;

- enforcement analysis, that includes a summary of activities, notices of violations, case dispositions, including statistical information on number of visitors, points of entry and areas and types of use, plus conclusions and recommended ways to improve management.

\section{c. Anchoring Study}

To explore methods of lessening the effects of improper anchoring and to assess the effectiveness of existing controls NOAA and DCCA will undertake a study to determine the feasibility and design of a mooring buoy system for the Sanctuary or a suitable alternative. Proper anchoring information will be disseminated to users.

\section{d. Public Education and Information}

The "living laboratory" aspects of the proposed Sanctuary can be fully developed to provide opportunities for the public to experience the interrelationship between man and the environment, in addition to understanding the significance of the resources and the implications of marine management. This educational aspect will be developed through field activities and media materials. A sanctuary user's guide will be a product that will enable the public and educators to better understand and more wisely utilize the resources. In conjunction with DCCA's Environmental Studies Program, other public education programs and the V.I. Department of Education, a coordinated sanctuary education program for both children and adults could be developed. Interpretative activities could be designated, possibly centering around a Sanctuary museum. The public will be encouraged to participate in organized tours and other "hands on" learning experiences. This use activity has been recommended for areas within the proposed sanctuary such as the Mangrove Lagoon, by the Coastal Zone Management Program of the Virgin Islands and by a number of other studies (Bellar et.al., 1970; Adams, et.al., 1975; Nichols and Towle, 1977). The Sanctuary Information Center wil distribute information on regulations and on-going activities and research within the Sanctuary.

\section{e. Research}

In an effort to provide baseline data upon which future change can be evaluated and future management decisions based, priority will be given to completing a biological inventory, reef health and water quality assessments. The diversity of habitat types, uses and biota within the proposed sanctuary offers extensive possibilities for research which will be encouraged. A long-term research and assessment program will be developed as a part of the Management Plan.

\section{f. Fishery Improvement}

The role of the Mangrove Lagoon and the remainder of the proposed Sanctuary waters in local fisheries has been documented in a continuing series of research efforts. These studies point out the importance of stemming the deteriorative 
trends within the Mangrove Lagoon in order to insure a continuing supply of juvenile fish, lobsters and crabs. To combat the continued degradation of the fishery, plans for its' improvement will be developed as a part of the Sanctuary Management Plan.

\section{g. Establishment of an Advisory Committee}

In May of 1979 the Marine Sanctuary Advisory Board (MSAB) was established to assist DCCA in developing the marine sanctuary proposal. The MSAB is a ten (10) person board attached to DCCA and consists of representatives of user groups that would be impacted by the proposed Sanctuary. The following groups were represented: Power Boat Racing Association, dive tour operators, St. ThomasSt. John Fisherman's Cooperative, St. Thomas Underwater Sports Club, Frenchtown Community Association, and the V.I. Conservation Society.

The MSAB initiated policy review of actions related to the proposed Sanctuary such as the development of rules and regulations. If a sanctuary is designated, the Board will remain in existence and continue to function in this policy review and advisory capacity to DCCA.

\section{h. Habitat Restoration}

Habitat restoration will focus on the Mangrove Lagoon. It will center upon the control of factors contributing to environmental degradation and upon increasing water circulation throughout the Mangrove Lagoon. Habitat restoration will be conducted by reopening major circulatory channels through dredging, by mangrove reforestation, stricter control over pollutants, and increased circulation for the lagoon.

\section{i. Designated Dive Areas}

To protect and enchance popular dive spots of particular value and to increase the capacity of sanctuary resources to cope with anticipated demands, certain areas may be set aside as special management zones. Associated activities would include the placement of instructive markers and signs, regular maintenance of the reef areas and the establishment of mooring buoys. Areas currently under consideration as special management zones are several diving areas know as Great Bay, the southwest point of Little St. James, the Cortensar Senior located off Buck Island, Packet Rock, Cow and Calf Rocks, and Nazareth Bay.

\section{j. $\quad$ Cultural Resources}

The proposed Sanctuary has a diversity of cultural resources. To more fully understand their history and to provide a mechanism that will ensure their survival, NOAA will fund an inventory and assessment of submerged cultural resources. NOAA will work closely with DCCA and the Virgin Islands State Historic Preservation Officer in developing that portion of the Management Plan dealing with protection of cultural resources. Properties eligible for inclusion onto the National Register of Historic Places will be identified. 
Through the Virgin Islands CZMA, regulations will be promulgated to provide protection to the proposal area, in addition to that al ready provided by the Virgin Islands and Federal law (e.g., the Marine Mammal Protection Act). DCCA has analyzed the activities affecting the area and has proposed draft regulations which have been approved by both the St. Thomas Coastal Commission and the Virgin Islands Coastal Commission (See Appendix A). NOAA has reviewed the controls imposed and concluded that they are adequate to protect the resources of the Sanctuary. Therefore, it does not propose any additional measures, but will adopt the measures as Federal regulations; thus making available Federal remedies for violations should the Virgin Islands wish to utilize them. The regulations are open for review and comments both under the Virgin Islands and Federal procedures. These reviews will be conducted concurrently and in connection with the EIS process. Final Virgin Islands regulations will be adopted by the St. Thomas Coastal Committee and the Virgin Islands Coastal Commission. If approved, the substantive provisions will be adopted by NOAA.

\section{a. SUBSTANTATIVE PROVISIONS \\ 1. Taking and Damaging Natural Resources}

a. No person shall break, cut, or similarly damage or destroy any coral, bottom formation or any marine plant, except dead shells. There shall be a presumption that any items listed in this paragraph found in the possession of a person within the sanctuary have been collected or removed from the sanctuary.

b. Only traditional fishing methods shall be permitted within the sanctuary. No person shall use poisons, electrical charges, explosives or similar methods to take any marine animal or plant.

\section{Operation of Vessels}

a. No person shall anchor on coral reefs or in any manner that damages coral or other natural or cultural resources. All practicable efforts shall be taken to drop anchors on sand flats, rock and rubble bottoms, and other areas without extensive coral formations. When anchoring dive boats, the first diver down shall inspect the anchor to ensure that it is placed off the corals and will not shift in such a way as to damage corals. No further diving is permitted until the anchor is placed in accordance with these requirements.

b. No person shall anchor in areas where mooring buoys have been placed by the Government of the Virgin Islands or NOAA.

c. No vessel under power shall approach closer than 200 feet to a fishing vessel or a vessel displaying a diving flag except at a maximum speed of three knots.

d. No vessel or person shall interfere with any fishing activity. 
e. All vessels from which diving operations are being conducted shall fly, in a conspicuous manner, the international code flag alpha "A."

\section{Alteration of the Seabed and Construction}

a. No person shall dredge, fill or otherwise alter the seabed in any manner nor construct any structure other than a navigation aid except as permitted by this section.

b. The following activities are allowed subject to the limitations and conditions imposed by the applicable permits and licenses issued under the Virgin Islands Coastal Zone Management Act, V.I.C. Chapter 21, Title 12, (VICZMA):

i) Construction of piers, docks, moorings, and similar structures, except in the Mangrove Lagoon (defined as an area from Bovoni Cay west to the shoreline of St. Thomas);

ii) Dredge and fill activities necessary for public service purposes, including but not limited to the burying and maintenance of cables and pipes; and

iii) Channel dredging within the area of Benner Bay and Bovoni Passage (defined as an area from the northwest point of Bovoni Cay, northeast to Benner Bay and in Benner Bay from a line drawn from the northeast corner of Bovoni Cay south to the northwest point of Grotto Cay, north to Compass Point) provided such activity can be clearly demonstrated to be in the public interest.

\section{Discharging of Polluting Substances}

No person shall litter, deposit or discharge any materials or substances of any kind except:

a. Indigenous fish or fish parts. Guard standards.

b. Effluent from marine sanitation devices allowable under coast

c. Municipal sewage from the existing outfall consistent with U.S. Environmental Protection Agency standards.

\section{Underwater Trails}

a. No person shall spearfish or fish at the underwater trails, except bait fishing.

b. No person shall mark, deface, or injure in anyway, or displace, remove, or tamper with underwater trails signs, markers or bouys.

\section{Removing or Damaging Cultural Resources}

No person shall remove, damage, or tamper with, any historical or cultural feature, including archaeological sites, historic structures, shipwrecks, and artifacts. 
7. Marine Mammals and Endangered Species

No person shall harass, disturb, harm or in any way injure any marine mammal or other species classified as endangered by the Federal or Virgin Islands Government.

\section{Damage to Fish Traps}

No person shall disturb, harm, or tamper with any legal fish gear, nets, traps, or pots.

\section{b. PERMIT PROCEDURES AND CRITERIA}

1. Permits for those activities allowed under section a.3.b. shall be issued in accordance with the procedures and criteria set forth in section 910 of the VICZMA.

2. Permits for those activities prohibited by section A may be issued by the Commissioner of the Virgin Islands Department of Conservation and Cultural Affairs in accordance with the Virgin Islands (VICZMA) and with this section provided such activity is either (1) research related to the resources of the sanctuary or (2) to preserve and protect the recreational and educational value of the sanctuary or (3) for salvage or recovery operations.

a. In addition to any other requirements under Section 912 in considering whether to grant a permit, the Commissioner shall evaluate such matters as (1) the general professional and financial responsibility of the applicant; (2) the appropriateness of the methods envisoned to the purpose(s) of the activity; (3) the extent to which the conduct of any permitted activity may diminish or enhance the value of the Sanctuary as an ecological, recreational, educational or scientific resource; and (4) the end value of the activity satisfies the criteria of this section; (5) such other matters as deemed appropriate.

b. At least 30 days prior to issuing any permit under this section, the Commissioner shall notify the Assistant Administrator for Coastal Zone Management, National 0ceanic and Atmospheric Administration 3300 Whitehaven Street, Washington, D.C. of the application and shall include a description of all proposed, activities equipment, methods and personnel involved (particularly describing relevant experience) and a timetable for completion of the proposed activity.

c. The Commissioner may seek and consider the views of any other person or entity, within or outside of the Federal Government.

d. NOAA Assistant Administrator for Coastal Zone Management or designated representative may observe any permitted activity and/or require the submission of one or more reports of the status or progress of such activity.

e. All information obtained pursuant to a permit issued under this section shall be available to the public. 


\section{Impacts of the Preferred Boundary Alternative}

This boundary alternative would provide a basis for achieving sanctuary goals. The preferred boundary option would create a sanctuary containing significant portions of the coastal environment off southeast St. Thomas, and would protect and manage a system rather than any one component. The "systematic" scope would provide for maintenance and enhancement of long-term productivity of the entire ecosystem.

This alternative includes the full component of resources necessary to protect and maintain the area as a viable marine system. It contains the most significant stand of fringing red mangroves on St. Thomas, habitats for endangered species and for important recreational and commercial fishing species, extensive coral reefs, open ocean areas and several shipwrecks.

Included within the alternative is the Mangrove Lagoon and several mangrove cays, the largest of which is Bovoni Cay (14 acres). Patricia Cay has extensive fringing mangrove growth on the north and west. The brown pelican (Pelecanus occidentalis), green sea turtle (Chelonia mydas), and hawksbill sea turtle (Eretmochelys imbricata) have been sighted within the area. Habitat for numerous kinds of birds which roost, feed and nest in and around the mangroves (such as doves, pigeons, the osprey and cattle egret), would be protected and managed. Habitat for some rare reptiles which are found in the mangrove, particularly the local snake (Alsophis) and the ground lizard (Amevia) would be included.

The alternative also contains large expanses of turtle grass flats which act as a juvenile habitat for many species of fish and mollusks such as small labinids, wrasses, latjanids and the spiny lobsters. The most popular dive sites off St. Thomas are located within the proposal area. Most of the significant coral assemblages reefs and wrecks are heavily used for snorkeling and SCUBA diving. Wrecks include the Cortanser Senior, Caridad, and HMS Wye. In addition, remains of an unidentified wreck are located at Packet Rocks. The most notable collection of corals and most spectacular reef development exists at Cow and Calf Rocks, in Christmas Cove off Great St. James, at Straggler Rocks, off south and west Little St. James, Dog Island in addition to portions of Buck and Capella Islands.

The area between Patricia and Cas Cay is interspersed with a back reef community of Porites. Coral reefs containing hard corals such Sidastrea, Acropora, Diploria, Millipora and Reontastrea exist throughout this boundary alternative. The reef assemblages also contain soft corals such as Pterogonia, Psecidopterogoria, Eunicia, and Plexamella as well as sponges.

The ocean areas within the alternative are pristine, contain coral reefs, and fine sand areas with Halimeda, marine meadows of Thalassia and Syringoduim, calcareous al gal plains and zones of rock and rubble where over 300 species of fish have been observed (Randa1, 1968). The areas of 1 ow relief are frequented by a variety of crustaceans that includes a recently discovered crab resource (01sen, Damann and La Place, 1978), mollusks including three species of conchs (stromibidae) plus a range of fish species dominated by porgies (Calamus sp.), pat snappers (Lutjanus synagris), and small grunts (Haemulon sp.). The algal plain is the extensive association areally, as it covers most of the sea floor 
deeper than 50 feet. The most obvious components are the spermatophyte Halophila baillonis, the green algae (Caulerpa, Halimeda, Udotera and Peniculus, and the phaeophytes (Lobophora, Dictyota, Anadynome, Valonia, and Avranivillea). The faunal component is dominated by sponges of which there is a large and colorful variety, particularly of Hasliclona sp. Other obvious animals whose habitat would be included are fighting conch (Strombus pugilis), carrier shell (Xenphora conchlopora), hermit crabs (Dardanus venuous and Clibanarious tricolor) and several species of burrowing polchaetes.

The area also contains Benner Bay, one of the most intensively developed marine areas of St. Thomas. Approximately 142 boats are moored or anchored within the Bay. Cowpet Bay includes the area containing the St. Thomas Yacht Club and where approximately 70 boats are moored or anchored at any one time.

\section{Impacts of Sanctuary Management}

The proposal creates a cooperative approach to establishment of the proposed sanctuary that recognizes unique local circumstances. It builds upon existing special area management and provides "undergirding" by NOAA to insure long-term protection.

The severe and imminent threats to the resources (identified in Chapter Four, Description of Affected Environment) will be mitigated by the promulgation of cooperatively developed protective rules and regulations by the V.I. which will be subsequently adopted by NOAA. Other impacts of designation would relate to the maintenance of a high degree of environmental quality and resource protection related to NOAA funding for management and enforcement. Sanctuary funding would augment territorial and other Federal monies to undertake a series of management tasks. There would be no adverse environmental impacts of designation. The proposal would not limit most existing local short term uses of the area but would result in long term enhancement of resource productivity. Designation will result in long term protection of the resources, with no irreversible or irretrivable commitment.

Data useful for management of both the sanctuary and other marine areas will be generated. The proposed anchoring study will assess the effects of stress on corals and benthic communities and the information will be utilized to develop and employ an anchoring system that will minimize damage and protect the resources. Monitoring wirefish trapping will supply data to determine future management needs. Research funding will provide data upon which future changes can be evaluated and management decisions based.

The proposed "living laboratory" approach to public education and information will result in greater public awareness of marine ecological concepts. Such awareness will decrease the incidence of illegal coral collecting, anchor damage to coral or pilfering of wrecks,

The proposed habitat restoration project for the lagoon would involve improving channel circulation and mangrove reforestation. The lagoon area is the most extensive in the Virgin Islands and the only one remaining on St. Thomas. Presently, the area is in need of corrective action to ameliorate existing degradation and to restore the habitat. In the past the lagoon was the most significant breeding and juvenile habitat for fish and conch off the coast of St. Thomas. Habitat restoration would enhance the fishery productivity and 
result in the revival of the area as a habitat for the spiny lobster (Panularius argus) and red snapper (Lujanus synognis), two economically important species.

Management strategies for cultural resources such as shipwrecks would be developed. The sites would be inventoried and assessed enabling NOAA and DCCA to make effective management decisions for protecting these resources. The Cortensar Senior which is extensively used by dive boat operators would receive management consideration that would review safety requirements needed for the anticipated increases in diving activities. The HMS WYE is a shipwreck also under consideration for special management. It is anticipated that a systematic excavation of the wreck will reveal artifacts such as anchors, cannons und other objects of cultural and historic value. Setting aside areas for use and data recovery will prevent degradation and maintain and enhance the resources.

Enforcement funds will enhance the efforts of the DCCA Bureau of Environmental Enforcement in policing the area and thereby better assure compliance with the Sanctuary regulations. This increased level of enforcement will result in a concomitant increase in protection of the resources.

The preferred alternative is consistent with and complementary to the goals and objectives of the National Program (see Chapter I, Introduction and Summary). A designation of these waters as a sanctuary would enhance the diversity of resources included within the national marine sanctuary system. The preferred alternative would also provide a site with great diversity in recreational and commercial fishing. Relatedly, the Sanctuary would provide an opportunity to study the effects of these managed uses under controlled conditions.

E. Alternative Three: Establishment of A Smaller Marine Sanctuary

As an alternative to the Status Quo and the Preferred Alternative (boundary altenative 1), NOAA and the Virgin Islands Government could establish a marine sanctuary of a smaller size. Under the smaller boundary option the cooperative administrative arrangement between the Virgin Islands and NOAA would remain the same as the preferred alternative (for a discussion of the preferred alternative and impacts please see Section C of this Chapter). There are two reasonable alternatives; boundary alternatives 1 , the preferred alternative and 3 (see Figure 2 ).

\section{Boundary Alternative 2}

Boundary alternative 2 would include much of the same area as Boundary Alternative 1, but would exclude areas such as Benner Bay and Cowpet Bay and the intertidal areas from Cowpet Point to Deck Point. This option would focus on the Mangrove Lagoon and open water areas.

Enforcement and management of Alternative 2 would be difficult. Separating a narrow intertidal zone surrounded by the proposed sanctuary would present problems in terms of enforcing regulations and expending management funds. In addition, the large number of recreational vessels that anchor, moor and discharge wastes within the area have been identified as an issue requiring management (see Chapter IV, Affected Environment). Exclusion 
of Benner Bay, Cowpet Bay and the intertidal zone will impair the ability of NOAA and DCCA to address impacts affecting the resources and to comprehensively manage and protect the proposed sanctuary.

\section{Boundary Alternative 3}

Boundary Alternative 3 would include many of the significant resources and exclude others. The Mangrove Lagoon/Benner Bay complex would be included. Hence, the extensive stands of mangroves, juvenile fishing habitat and grass bed areas would be included but the reef and dive area at Packet Rocks and the wrecks and dive spots off Buck and Capella Islands would not. The developed Benner and Cowpet Bays would also be included.

Boundary Alternative 3 would deny sanctuary status to the stretches of open water between the St. James Islands and Buck Island. The pelagic zone and extensive algal plains that are biologically important would not be included. These open water areas which also serve as migratory paths and feeding grounds for sea turtles and whales would not be protected and managed as part of the Sanctuary.

The smaller boundary alternatives would produce a sanctuary that includes a different configuration of resources than the preferred alternative (Alternative 1 figure 2). Neither of these alternatives would focus management attention on an area that functions as a ecological unit. As indicated in Chapter IV, Description of the Affected Environment, there is a direct biological interrelationship between the intertidal and marine portions of the area under consideration. The area off southeast St. Thomas al so functions as a recreational unit. Developing and implementing management strategies for certain dive sites and recreational spots within the proposal area, but not others, might inappropriately encourage use in some areas and discourage recreational use in others. 

I. Natural Environment

A. Geology

The proposed Sanctuary represents a former Pleistocene back-reef lagoon type environment, as does ninety percent of the St. Thomas bank shelf. Drowned Pleistocene reefs are present in three narrow $(300-400 \mathrm{~m})$ banks along widely separated zones offshore. They have slightly different mean depths and correspond to time intervals when the rising sea level was at a temporary stand still. These reefs are best defined east of longitude $64^{\circ} 55^{\prime} \mathrm{W}$.

The sedimentary geology was investigated in the proposed sanctuary by Hubbard (1979). The Hubbard report outlined the oceanography and sedimentology of the area and included a synopsis of available information on currents, sediment transport, and sediment control. The report identified three major sedimentary regions. The first of these occurred in the region of the major passes where heavy tidal currents may transport as much as a million cubic meters of sediment into St. James Bay annually. West of this area in St. James and Jersey Bays, slower wind driven currents may create conditions of onshore transport of sediments. The report stated that within Benner Bay and the Mangrove Lagoon, the major factor explaining sedimentary deposition was transport of terrestrial sediments from runoff caused by the steep slope of the island and the erodable nature of St. Thomas soils.

\section{B. Climate and Current}

The climate of the area is subtropical and semi-arid. Temperatures vary between 70 and $85+^{\circ} \mathrm{F}$ with the mean annual temperature about $79^{\circ} \mathrm{F}$. Air circulation is dominated by the trade winds. Wind speed range from eleven to twentyone knots. Winds from the east dominate March to 0ctober and winds from the northeast dominate from November to February. Periods of strong (20knots) northerly winds are common from December to February. Rainfall averages about 41 inches per year, most of which falls between August and December (VI Planning Office \& Coastal Zone Management Program, Technical Supplement No. 1, 1977).

Sea and swell are predominantly from the eastern quandrant throughout the year; those locations which are sheltered from this quandrant experience little or no swell and predominately low seas (VanEepol, et. al. 1971). Tidal ranges on the southern Virgin Islands platform vary from an average of $12 \mathrm{~cm}$ to a maximum of $24 \mathrm{~cm}$ at the time of spring tide (Holmes, 1978).

The offshore currents are dominated by a branch of the equatorial current and come from the east during most of the year with a slight shift to the south during the summer months. Velocity is consistently around $27 \mathrm{~cm} / \mathrm{sec}$ $(0.5 \mathrm{kt})$. This wind and current relationship dominates the central and of $\mathrm{f}-$ shore portions of the proposed sanctuary including Jersey Bay and the areas between the St. James Islands and Buck/Capella Islands. The inshore area is dominated by tidal currents in the narrow passes and to the east of the St. James Islands. Hubbard (1979) noted that current flow continued after peak tides and suggested that there were hydraulic differentials which persisted 
the phenomenon. Currents in this region were observed up to $75 \mathrm{~cm} / \mathrm{sec}(1.5$ $k t)$. These current patterns are shown in Figure 3 .

In the open areas of St. James Bay and Jersey Bay the prevailing current is a slow wind driven drift around $10 \mathrm{~cm} / \mathrm{sec}$ in a northwesterly direction. Most sediment transport in this region is affected by wave generated currents.

The currents of the inner portions of Benner Bay and the Mangrove Lagoon are also dominated by wind driven movements. Water flows over the passages between St. Thomas and Patricia Cay and between Patricia and Cas Cays. Additional wind driven waters also enter Benner Bays. These current velocities are generally very 1 ow (less than $10 \mathrm{~cm} / \mathrm{sec}$ ). 


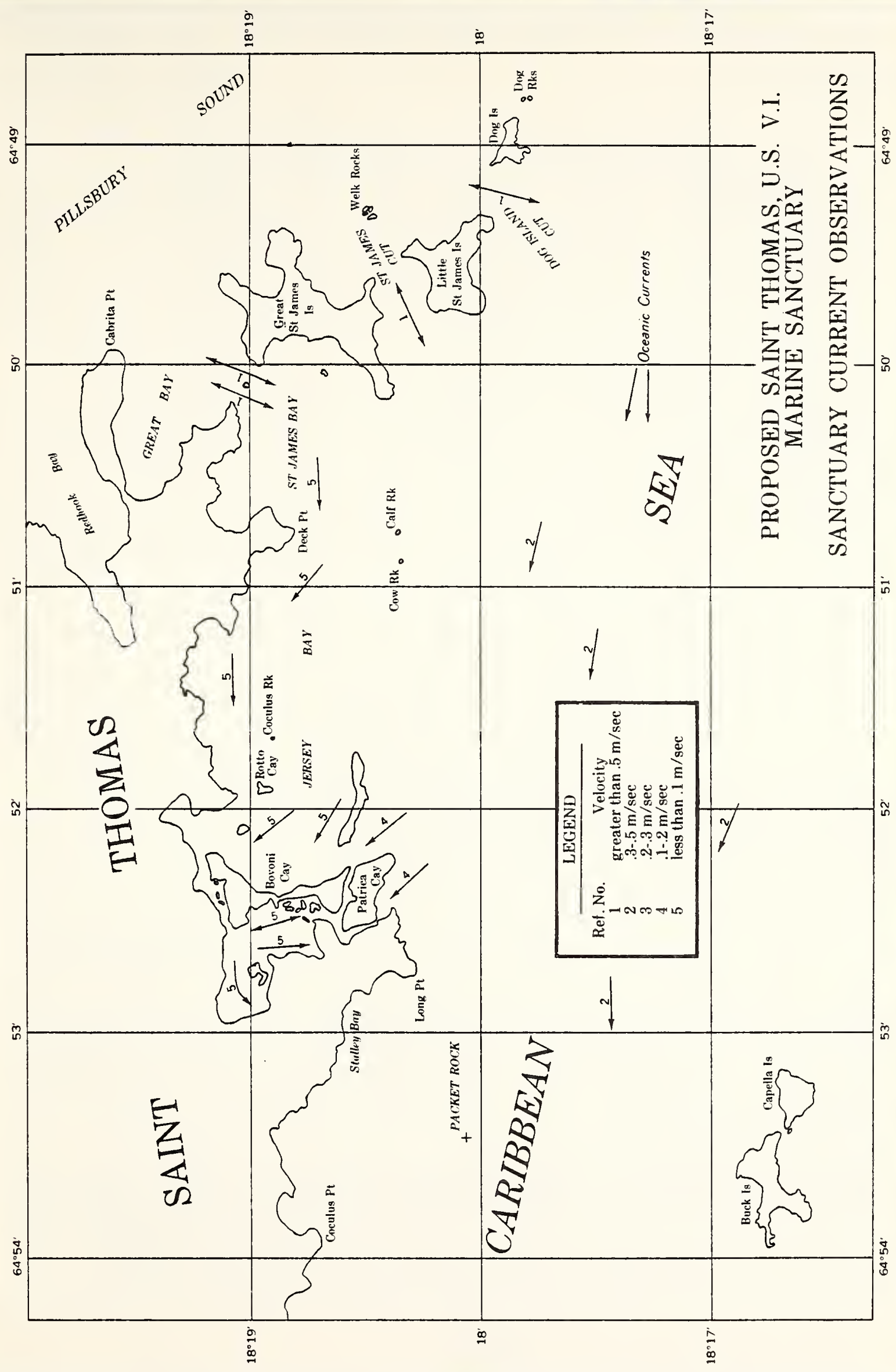

인 
Nine offshore islands and cays listed in Table 1 are located within the proposed sanctuary.

TABLE 1. OFFSHORE ISLANDS AND CAYS IN SANCTUARY AREAS

$\begin{array}{lll}\text { Island/Cay } & \text { Size } & \text { Ownership } \\ \text { 1. Bovoni Cay } & 50 \text { acres } & \text { Private } \\ \text { 2. Buck Island } & 42 \text { acres } & \text { Federal } \\ \text { 3. Capella Island } & 22 \text { acres } & \text { Virgin Islands Govt. } \\ \text { 4. Cas Cay } & 14 \text { acres } & \text { Private * } \\ \text { 5. Dog Island } & 12 \text { acres } & \text { Virgin Islands Govt. } \\ \text { 6. Patricia Cay } & 33 \text { acres } & \text { Private } \\ \text { 7. Rotto Cay } & 2 \text { acres } & \text { Private } \\ \text { 8. Great St. James } & 157 \text { acres } & \text { Private } \\ \text { 9. Little St. James } & 69 \text { acres } & \text { Private }\end{array}$

* This may become V.I. Goverment property.

The offshore islands are uninhabited and similar in ecology and appearance. They are aesthetically spectacular, with windward rocky shorelines, sheer cliffs, and massive boulders. The leeward bays, coves and rocky points offer many of the finest dive sites and anchorages in the Virgin Islands. The islands are volcanic in origin, dry in character, and covered with thin stoney soil.

The beach ridges of the offshore islands and cays mark where the substrate consists of coral fragments from the high tide to the inland limits. Shells support a hardy community of growth forms able to withstand the salt stress and mechanical forces common to beach areas. Sea grape (Coccoloba uvifera), cactus (Cephalocereus and Opuntia), saltwort (Batis maritima), bay bean (Ipomoea pes-caprae), and sea spinach (Sesuvium portulacastrum) are prevalent. Behind this initial zone of beach vegetation may be found white frangi pani (Plumeria alba), palms (Cocos nucifera and Coccothrinax alta), Agave sp. and casha (Acacia farnesiana).

The cays of the Mangrove Lagoon (Rotto Cay, Manglar Cay, Cas Cay, Patricia Cay and Bovoni Cay) support a unique and simple vegetative cover of red, white and black mangrove trees representing one of the few remaining mangrove stands in the Virgin Islands. The prop roots provide protection for marine species, particularly juvenile fish and lobster; tree branches support a host of waterfowl. Few other plant species with the exception, of buttonwoods 
(Conocarpus erectus) and saltwort are associated with the mangroves.

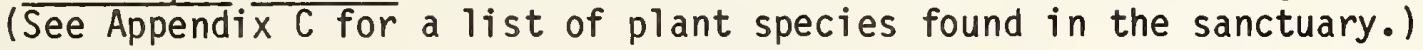

\section{Biological Zones}

\section{Mangrove Lagoon/Benner Bay}

The lagoon area of Jersey Bay is the only significant mangrove system in the Virgin Islands. Several cays (Bovoni, Patricia and Cas Cays) and a number of manglars (mangrove hummocks) are located there. Cas and Patricia Cays, are both interspersed with spectacular reefs, and form the southern barrier of the lagoon. They both consist of precipitous windward sides facing south and east, and have headlands with long mangrove flats dominated by white cedar and buttonwoods leeward (north and west of the cliffs).

The entire area within the Jersey Bay (Mangrove Lagoon Benner Bay Complex) is bordered by an extensive red mangrove stand (Rhizophora mangle) which supplies much structual shelter for a rich and diverse root community, fish forms, and an extensive bird community. The Island Resources Foundation reported 79 species of fish, in addition to the spiny lobster in the Jersey Bay Mangrove system. The population of fish supported by the Mangrove Lagoon was estimated at more than 50,000 individuals (V.I. Sand Dredging Study: Preliminary Synthesis Available Data). Prior to the stresses from development, there were extensive populations of juvenile lobsters and crabs.

Three basic biotic associations occur in the Mangrove Lagoon and Benner Bay: (1) turtle grass flats, (2) sand filled channels, and (3) reef flats. In parts of the area, conditions of extreme turbidity, eutrophication, boatrelated turbulence and siltation have favored certain species from these associations over others. Therefore, at present there are at least eight recognizable communities which will be discussed (See Figure 4).

The most widespread community in the past has been that community dominated by the turtle grass (Thalassia testudineum). This extremely productive association is generally over 80 per cent turtle grass with regular appearances of another spermatophyte, Syringodium filiforme and the Chlorophytes, Halimeda, Penicillus, Avrainvillea, and Udotea (Figure 4). The turtle grass community serves as a juvenile habitat for many species of fishes and spiny lobsters and is important to the nearshore fish resource. Over the past decade, it is this community that has shown the most change.

Survey work in the late sixties (McNulty, Robertson and Horton, 1968; Tabb \& Michel, 1968) revealed that turtle grass dominated the area of Jersey and Benner Bays and the Mangrove Lagoon until the early part of the decade when 01 sen and Dammann (1971) noted large areas of mud bottom. In many cases the turtle grass community has been replaced or survived by an al gal dominated community, the predominant forms being Halimeda and Penicillus. Other common components are the chlorophyte Acetabularia crenulata and various Caulerpa species, the rhodophytes Gelidium sp., Acanthophora spicifera, the phaeophyte Dictyota divaricata, and the spermatophytes Halodule and $\mathrm{HalO}$ phila baillonis. 


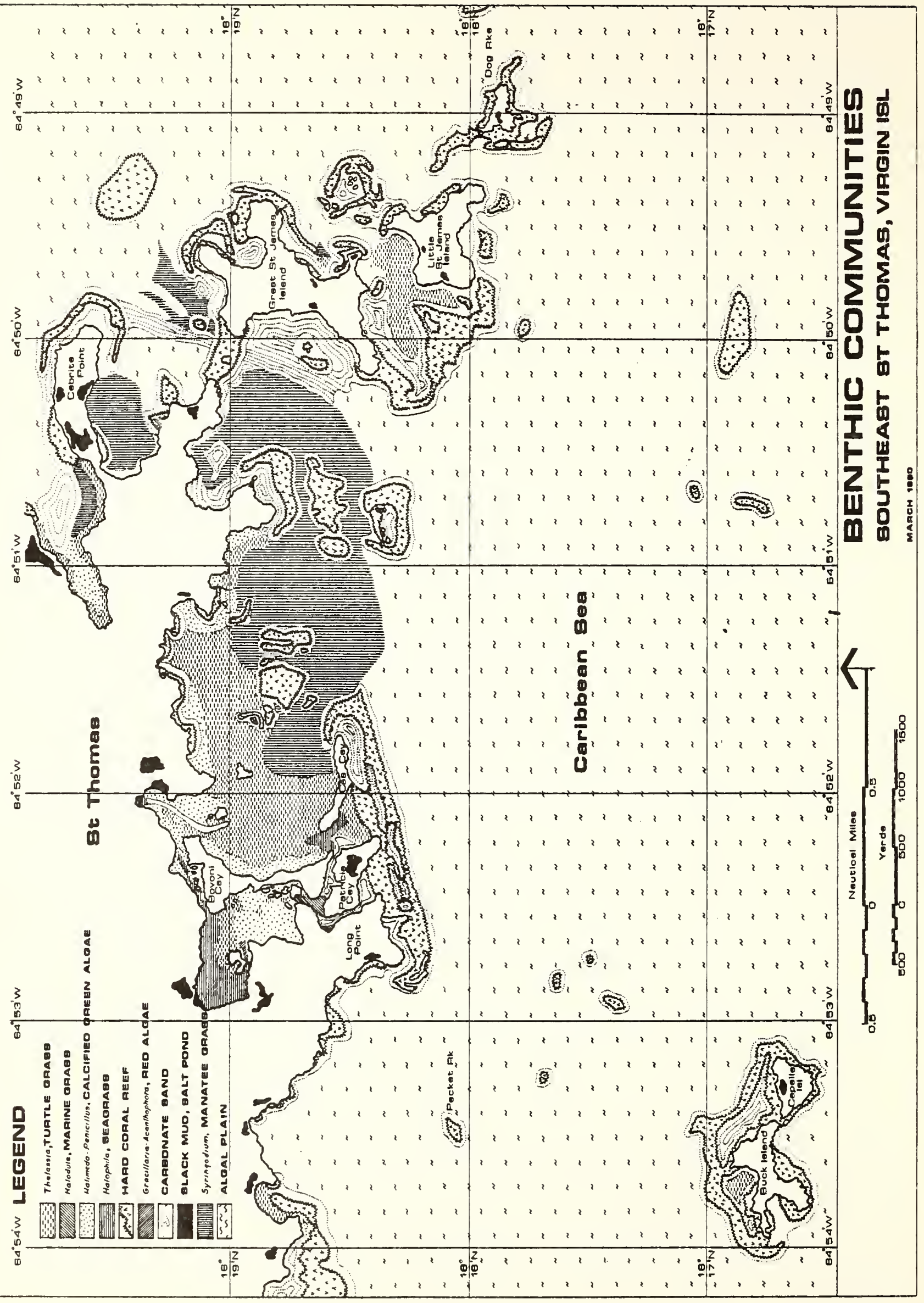


The ichthyofaunal component is very similar to the small labrids, wrasses and lutjanids that one finds commonly over the turtle grass flats. The algal species are all found in the deeper sublittoral zone, evidence that they may be preadapted for the lower light intensities encountered in the high turbidity waters that resulted from increased development in the surrounding watershed and from eutrophication. The benthic jelly fish Cassiopea has also increased greatly in population density over the recent years. Individuals are frequently found on the bottom within the Penicillus - Halimeda community. Presently, they cover almost all of the bottom in the Mangrove Lagoon, Bovoni Passage and much of Benner Bay in a zone extending roughly $15 \mathrm{~m}$ from the mangroves. 
In certain parts of the lagoonal complex, deteriorating water quality has resulted in the formation of an area of loose semi-liquid sediment which is covered by the spermatophyte Halophila baillonis. This species has been shown to be tolerant of unstable substrates (01sen and Sheen, 1974). It is a superior competitor in stressed situations but is easily displaced by other algal species when conditions permit their growth. Ninety percent of the inner lagoon is covered with this community in addition to an occasional growth of Caulerpa cupressoides, Udotea flabellum and Avrainvillea nigricans. This community extends through Bovoni Passage and is found in deeper parts of Benner Bay. The Halophila community appears to be the successor to the al gal Halimeda-Penicillus community.

In the extreme eastern portion of Benner Bay, two well defined zones of sabellid worms exist. The first consists of scattered large individuals in the sediments themselves. The second zone is covered by a matrix of smaller sabellid tubes above the sediments. Algal cover does not begin until about 10 meters east of the channel itself. This strong zonation would seem to indicate that there is an intense gradient or change in the south-east sector of Benner Bay.

Several other biotic groups were observed in association with the reefs in entrances and connecting channels of Patricia Cay. McNulty, et al (1968) showed that the back reef community of Porites extended through both entrance channels into the 1agoon. The Porites segment in the Patricia entrance was alive in 1971 but is now almost completely dead.

There is an area of fine sediment covered by rhodophycean al gae Gracilaria Cyclindrica and Acanthophora spicifera immediately to the south of Middle Island in the Mangrove Lagoon. McNulty, et. al., 1968 reported this area as one of the first where the black mud became covered by Halophila. Both of these algae are commonly found in quiet back waters and may well be favored by conditions of heavy nutrient input.

Cas Entrance reach was initially filled with Porites rubble and living corals (McNulty, et al 1968). Subsequent surveys have shown it to be covered with the Halimeda-Penicillus community (Grigg, et. al., 1971), turtle grass (Tabb and Michel, 1968) and a fine calcium carbonate sand (01sen, 1979). Presently, the fine sand covers part of the area while turtle grass and scattered algae cover the eastern portion. The major change in this area is a large and expanding area dominated by the spermatophyte Halodule that contains many small rhodophycean algae which cover the eastern portion. Aerial photos and field observations of the past 5 years al so indicate that the Halodule area is expanding. Possible factors responsible for this change need further investigation.

Benner Bay and the Mangrove Lagoon area has been demonstrated by 01 sen (1979) to be a major nursery ground for fishes. He also found that over 80 percent of the reef fish specimens noted in the area were juveniles. Additionally, a resident fauna characterizes the area, as well as a number of species which use the area for breeding purposes. 


\section{Ocean areas}

With the exception of Jersey Bay (Mangrove Lagoon, Benner Bay) the waters within the proposed sanctuary area are pristine. The benthic habitat is characterized by coral reef, fine sandy areas with transitional algae (Halimeda), marine meadows of turtle grass (Thalassia) and manatee grass (Syringodium), calcareous algal plains, and zones of rocks and rubble. There are over 300 species of fish which have been observed in the coral, grass beds, and sandy areas of the sanctuary (Randal, 1968).

Most of the offshore areas (Figure 4) within the proposed boundaries are covered by a rich and diverse algal plain. This area of low relief is frequented by a variety of crustaceans including a recently discovered crab resource (01sen, Dammann and La Place, 1978), mollusks, including three species of conchs (Strombidae) and a range of fish species dominated by porgies (Calamus sp.), pat snappers (Lutjanus synagris), and small grunts (Haemulon sp.). This community is extremely productive under ormal conditions, but is sensitive to light reduction (Wells and 01 sen, $1 j 74$.. The algal plain is the most extensive association areally, as it covers most of the sea floor below 50 feet. The most obvious components are the spermatophyte Halophila baillonis, green algae (Caulerpa, Halimeda, Udntea and Penicullus, Anadyonome, Valonia, and Avranvillea) and pheaophy :é 'Lobophora and Dictyota). The faunal component is dominated by sponges including a particularly large and colorful variety, Haliclona sp. Other obvin.., animals are the fighting conch (Strombus pugilis), carrier shell (Xenchord conchylophora), hermit crabs (Dardanus venosus and Clibanarius tricolor, and severat species of burrowing polchaetes.

Between Great and Little St. James is an extensive juvenile conch bed [Haines and Brownell (1978) and Sigma Environmental (1979)]. This area is under heavy recreational fishing pressure. Colonies of the West Indian fighting conch are located in Great Bay and in the St. James Passage.

\section{Senthic Communities}

Inshore from the algal plain, a number of deep reefs have been located [Adey (in Buros, 1979)] (Figure 4). Since hermatypic corals contain al gae which are phototrophic producers, the distribution of species is in part dependent on depth (light penetration) as well as water clarity. The maximum diversity of forms occurs in the range between 40 and 60 feet (Jaap and 01 sen in progress) where conditions are optimal for the growth of the massive corals like siderastrea. There are also large numbers of alcyonarians, gorgonians and many species of fish. Randall (1968) has described the diversity of forms which make up the local fishery valued at nearly 2.5 million dollars (0lsen, 1974). This habitat also includes many crustaceans such as the spiny lobster (Panulirus argus).

The reef community is quite variable. It includes a range of assemblages including gorgonian (soft coral) forests characterized by Pterogorgia, Pseudopterogoria, Eunicea, Plexaurella and sponges. In shallower water the reef is dominated by hard corals, principally, Acropora palmata (elkhorn), A. cerviconis (staghorn), Diploria (brain), Agaricia (rose), Millipora (fíre) and Montastrea. The condition of these reefs within the sanctuary is generally very good. 
Offshore from the reef community is the characteristic sand zone which typically separates the reefs in the Caribbean area from the deep water algal association. It has limited infauna and is generally devoid of benthic flora as a result of grazing by reef fishes and the black urchin (Diadema antillarum). The spermatophyte Halophila baillonis frequently dominates an early successional association at the deeper edge of the sand zone as it grades into the algal plain.

The shallower edges of the deep reef association and its associated communities are generally occupied by a plant-dominated marine meadow or algal plain community which is characterized by Syringodium filiforme, Penicillus capitatus, Avranvillea nigricans, and a variety of brown and green algae. This algal plain community covers much of the Virgin Islands shelf. Much of the life in this area is adapted for reattachment after transport. This community generally grades into a shallow water turtle grass community which is 50 to 80 percent Thalassia testudinum. These turtle grass beds are an important nursery ground for spiny lobsters (01sen, Hernkind, and Cooper; 1975).

\section{Endangered Species}

There are several endangered species in the proposal area including sea turtles, brown pelican, and the humpback whale. Sea turtles in the St. Thomas area are no longer common, and only two or three sites still serve for nesting purposes. Sea turtles have been known to nest on the beaches of Great St. James, Dog Island and Great Bay (Towle, et al., 1978) and are frequently sighted at the ledges of St. James and in other areas of the proposed sanctuary. They include: the green sea turtle (Chelonia mydas), hawksbill sea turtle (Eretmochelys imbricata), leatherback sea turtle (Dermochelys coriacea), ol ive ridley turtle (Lepidochelys ol ivacae) and the loggerhead sea turtle (Caretta caretta).

A variety of sea birds, including the endangered brown pelican (Pelecanus occidentalis), use the waters and surrounding mangrove areas for both nesting, feeding and roosting. These birds feed in large part on the same resource utilized by the many fishermen who capture bait from these waters.

The waters to the north and east of the sanctuary area serve as one of the many migrational paths for the humpback whale (Megaptera novaengliae) as it enters the Caribbean from the Atlantic.

\section{Cultural and Historic Resources}

DCCA undertook an inventory of cultural and historic resources in the proposed sanctuary. The report described known shipwrecks and historic maritime use in the proposal area.

The proposed sanctuary is known to contain several cultural and historic resources (see figure 5). During the eighteenth and ninetenth century St. Thomas harbor was a commercial center of regional importance. The volume of maritime traffic was considerable. Much of this maritime traffic passed through the proposed sanctuary as ships headed to and from Charlotte Amalie Harbor. A 1775 chart by the English cartographer Thomas Jeffreys shows the Current Hole Passage (referred to as the "St. James Passage") as a major 


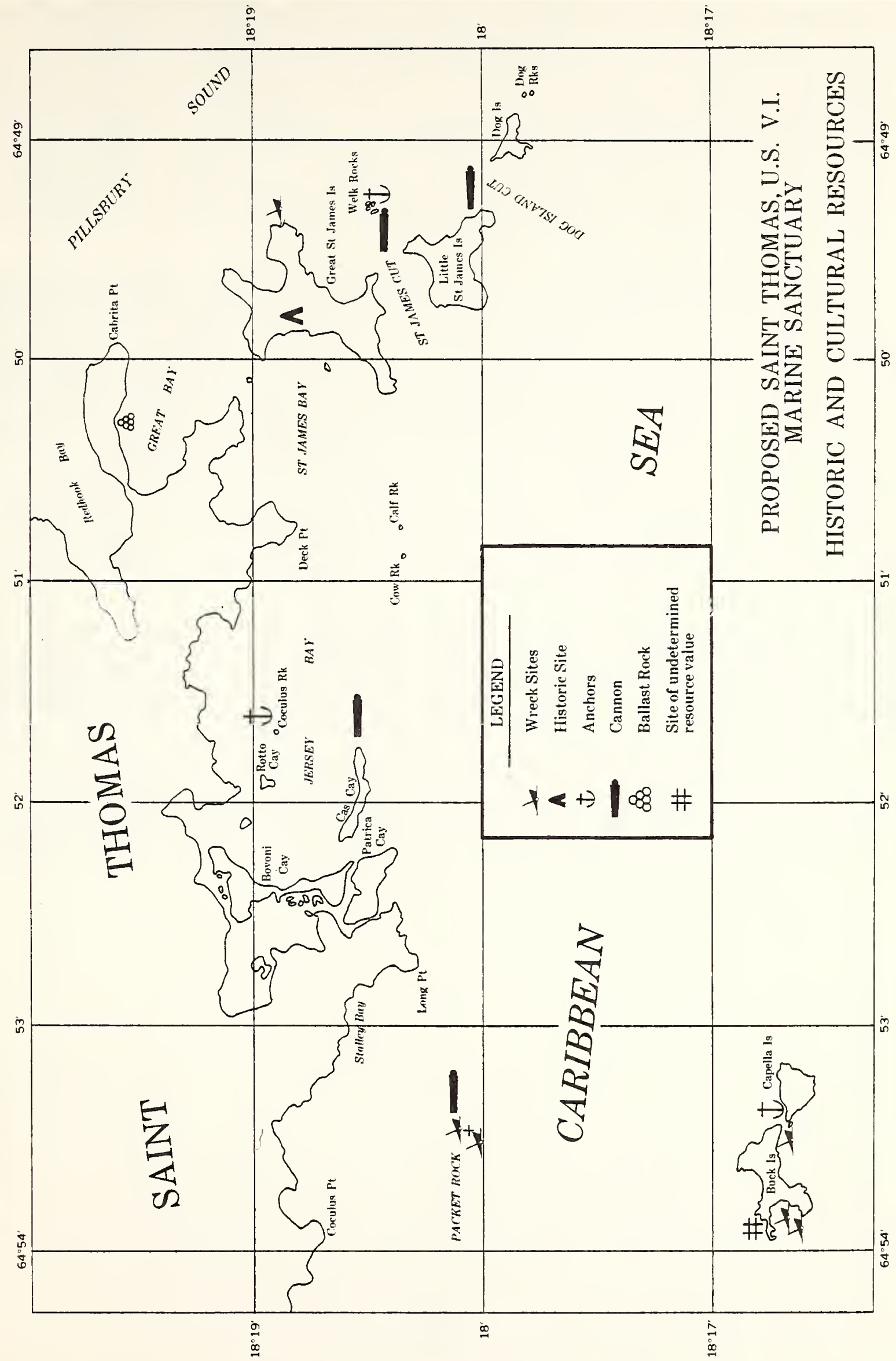


navigational channel of the time, and a survey of subsequent navigational guides indicates that a significant percentage of St. Thomas' trade with Europe and the islands of the Eastern Caribbean transected proposed sanctuary waters at one time or another. Moreover, during the frequent periods of intercolonial warfare, privateers of all nations anchored off Buck Island in the proposal area, hoping to surprise and capture trading vessels (Tyson, 1977). Given the volume of trade, the shallow reefs, natural hazards like Packet Rock, shifting wind conditions and often unpredictable currents, the area of the proposed St. Thomas Sanctuary was the site of many shipwrecks, some of which are as of yet undiscovered.

Although a systematic survey has not been undertaken, preliminary investigations have revealed six shipwreck sites within proposed sanctuary waters. These wrecks are: 1) the HMS WYE, a Royal Mail Company Packet Steamer, which sank off Buck Island during the hurricane of $1867 ; 2)$ the Cortenser Senior, an early twentieth century freighter of Panamanian registry, which sank off Water Island in 1973 and was recently relocated in the calm waters of West Cove, Buck Island; 3) a barge of unknown origin 4) the Jubal Cain, a British vessel which stranded on Packet Rock in February, 1880; 5) an unidentified vessel, possibly the Warwick dating from the early nineteenth century which sank on Packet Rock; 6) the Caridad, an inter-island trading schooner, which sank off the Great St. James with a cargo of cement in 1971. Collectively, these wreck sites reflect much of the maritime history of St. Thomas and most provide fascinating diving opportunities.

All of the known wreck sites appear to have been excavated to some extent, either by professional salvagers or recreational divers. However, it is likely that systematic excavation of the wreck site of the HMS Wye and the unidentified, early nineteenth century wreck on Packet Rock will aide in data recovery and reveal previously unrecovered artifacts.

In addition to the known wreck sites, objects of cultural and historical value, such as anchors, cannons, ballast rock and other items suggestive of unknown wrecks have been found at several places throughout the proposed sanctuary. At least one other early nineteenth century ship is known to have sunk off Packet Rock, but has not been located to date. 


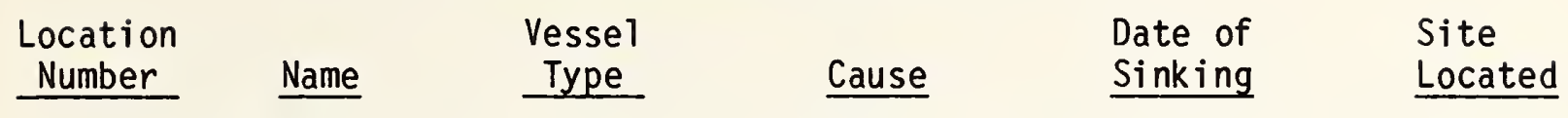

Buck Island

\begin{tabular}{|c|c|c|c|}
\hline HMS Wye & Steamer & hurricane & Oct. 1867 \\
\hline$\frac{\text { Cortenser Senior }}{\text { unknown }}$ & $\begin{array}{l}\text { Freighter } \\
\text { Barge? }\end{array}$ & $\begin{array}{l}\text { deliberate } \\
\text { unknown }\end{array}$ & $\begin{array}{l}1973 / 1979 \\
\text { unk nown }\end{array}$ \\
\hline
\end{tabular}

Packet Rock

$\begin{array}{llllrc}4 & \text { Jubal Cain } & \text { Iron hull } & \text { hit rock } & \text { Feb. } 1880 & \text { Yes } \\ 5 & \text { Warwick } & \text { Brig } & \text { hit rock } & 1816 & ? \\ 6 & \text { unknown } & \text { Brig } & \text { hit rock } & 1813 & ?\end{array}$

Great St. James

7 Caridad $\quad$ Schooner engine failed $1971 \quad$ Yes

There are no known Indian settlement sites within the boundaries of the proposed sanctuary, however, such sites may well exist underwater. Field surveys of Buck Island, Great St. James, and the St. Thomas shoreline have found no evidence of aboriginal habitation. The earliest circum-Caribbean date for the presence of man thus far is about 17,000 B.C., at which time the eustatic sea-level was approximately 300 feet lower than at present (Nicholson, 1976). It is possible, therefore, that submerged Indian sites could be found anywhere within proposed sanctuary waters, particularly in certain shallow water areas, such as Great Bay or the stretch of water between Little and Great St. James. 
IV. Socio-Economic Setting

\section{A. Overview}

The Virgin Islands has experienced tremendous growth over the past twenty years and that growth is expected to continue. In the last sixteen years the population has tripled from about 32,000 in 1960 to an estimated 95,000 inhabitants in 1976 (Virgin Islands Department of Health estimates). The majority of this population increase can be attributed to the influx of immigrants from nearby islands, and to a lesser extent, immigration from the continental United States. The Virgin Islands Planning Office has estimated that 60 percent of the population growth for the 1960-1979 period was attributed to immigration rather than natural increases.

The impetus for this rapid growth has been largely the result of increased employment opportunities associated with the expanding tourist industry, and numerous territorial governmental policies which have encouraged economic development (VICZMP, 1978). Employment opportunities have brought the standard of living in the Virgin Islands to the highest in the Caribbean. Estimated personal income per capita was $\$ 3,200$ in 1972 .

Tourism is important to the economic base of the territory, and in 1973 it was estimated that the industry was directly responsible for 20 percent of all employment (VICZMP 1978). St. Thomas is the center of the majority of tourism activities conducted in the territory. More than three-fourths of all air visitors to the islands spend their time in St. Thomas. In addition, the vast majority of cruise ship calls are made to St. Thomas. In 1973, tourist expenditures in St. Thomas accounted for 70 percent of the total tourist spending in the Territory.

While in the Virgin Islands most tourists involve themselves in wateroriented activities. Of the 353,000 tourists in the Virgin Islands for overnight stays in 1977, 52 percent snorkeled and SCUBA dived, 85 percent swam, 31 percent sailed and 7 percent fished (Davidson-Peterson, Exit Survey 1976-77 for the VI Department of Commerce). The Virgin Islands has received extensive coverage in major skin diving magazines regarding the excellent opportunities for diving. It is likely that the number and percentage of tourists interested in water-oriented activities will continue to increase.

St. Thomas is the center for all boating activity in the U.S. Virgin Islands. While the water sports industries and related facilities are primarily tourist oriented, they also serve many island residents. The proposed sanctuary is adjacent to the mainland of St. Thomas. The popular Buck and Capella Islands, also within the proposal area, are 15 minutes by boat from downtown Charlotte Amalia. These areas, along with the other offshore islands and cays within the proposed sanctuary boundary receive approximately 1,000 visits by boats yearly.

In 1979, a survey of recreational boating and fishing was undertaken. The study, Socio-Economic Survey of Recreational Boating and Fishing in the U.S. Virgin Islands (Socio-Economic Survey) (01sen, 1979), polled 1,789 registered boaters in the Virgin Islands during 1978, of which 987 were registered in St. Thomas. The survey assumed a fleet size of 2,000 for the 
entire Virgin Islands and of that two-thirds were based in St. Thomas. The survey revealed the average size of registered boats in St. Thomas to be 25.1 feet as compared to the United States average of 29.8 feet.

In determining the geographic distribution of Virgin Islands recreational boating in the territory, the study divided the area into various reporting areas designated as T's. The T-2 reporting area includes the waters to the south of St. Thomas -St. John (see Figure 6) and encompasses the area of the proposed sanctuary. The northern boundary is an imaginary line running from Red Point, St. Thomas to Lind Point, St. John. The western boundary is an imaginary line extending from Signal Hill, St. Thomas, to the eastern edge of Frenchcap Cay. The eastern boundary consists of an imaginary line running from Camelberg Peak, St. John, through Rams Head Point, St. John, and out to the territorial sea boundary.

More than 19 percent of all recreational boating activities around St. Thomas - St. John take place within reporting area T-2. Of these activities, 59.5 percent is boating, 9.5 percent snorkeling, 5.3 percent SCUBA diving, 5.3 percent recreational line fishing, and the remaining 20 percent is spearfishing, skiing, and other activities.

DCCA undertook several small scale studies in order to obtain data for the DEIS. The following studies were prepared and incorporated into the drafting of the DEIS. The studies include:

- Recreational Diving Inventory -- This report gathered information on diving activities within the preferred boundary alternative and included a description of the geographic features affecting its use, special features, typical biological features encountered, as well as a description of commercial diving activity, with estimates of dive days by both commercial and recreational divers.

- Commercial Fishing Industry -- This report quantitatively describes the commercial fishing activities, including person days spent fishing and species caught, number of commercial boats using the area, traps currently within the proposed sanctuary boundary, and catch estimates.

- Recreational Boating Inventory -- This report details the use of the proposal area by recreational boaters, including charter and racing boats.

The following discussion provides information on human activities within the proposed sanctuary and their socio-economic impacts.

\section{B. Human Activities}

1. Diving and Spearfishing

Recreational diving is an important activity occurring within the proposed Sanctuary. The numerous offshore islands, cays and reef outcroppings lying in the relatively shallow protected waters have made this area of St. Thomas a diver's paradise. 


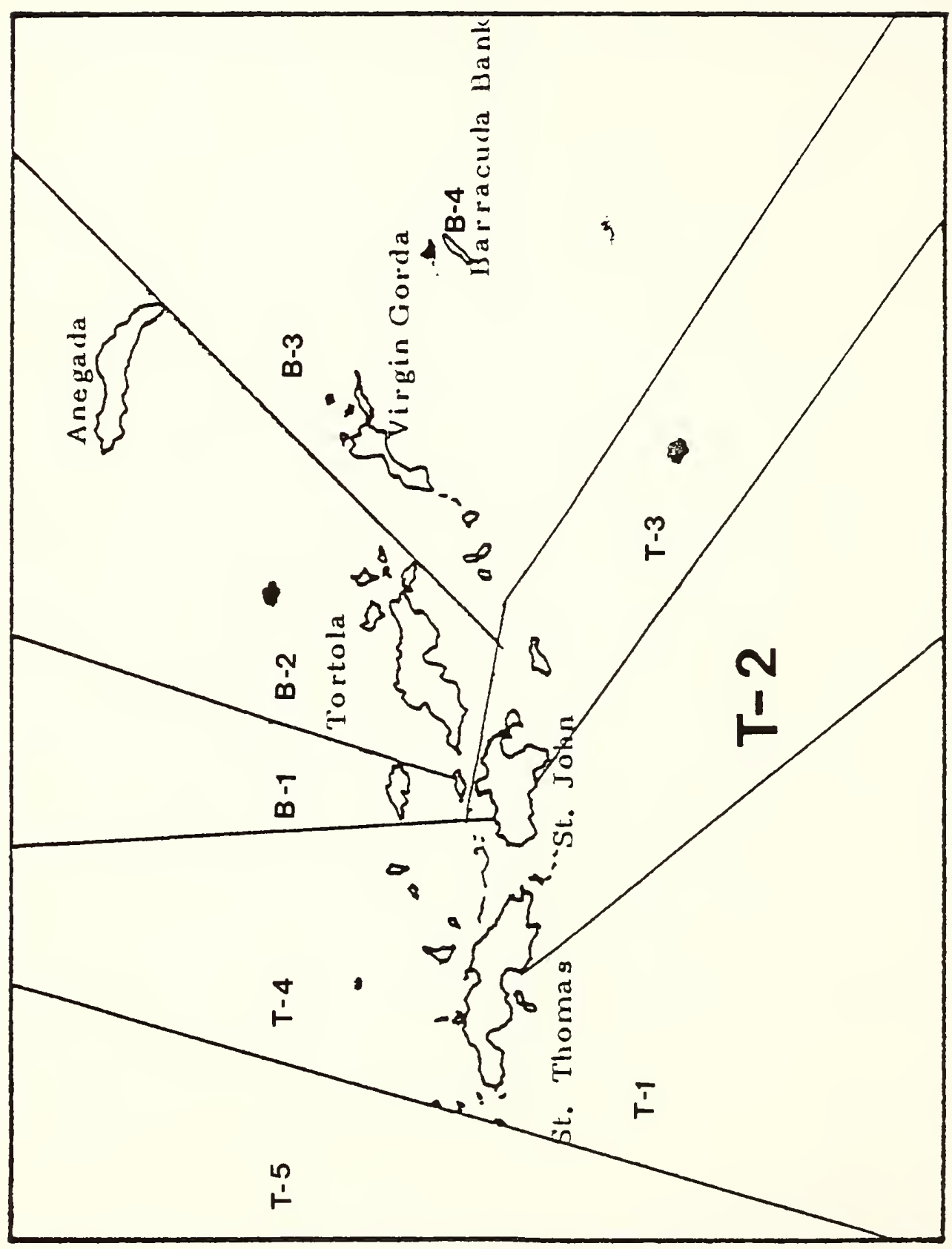

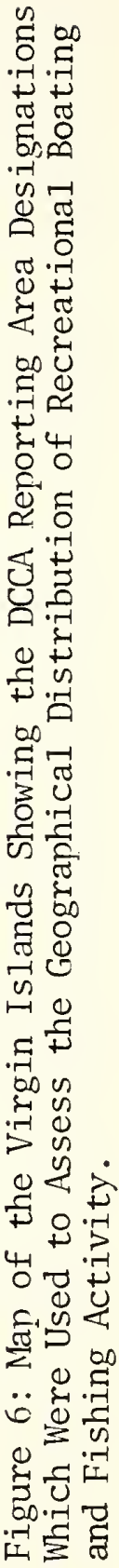


Eleven watersports companies in the St. Thomas-St. John area were surveyed as part of the Recreational Diving Inventory. Together they have a fleet of 15 boats and employ 68 people as diving guides and instructors for snorkling, SCUBA, and photography. Seven of the eleven companies have been in operation for more than 5 years. They serviced more than 30,647 divers in 1978 and approximately 28,876 divers in the first nine months of 1979 . The projected total for 1979 was 38,500 divers. SCUBA divers and snorklers are taken to the offshore islands and cays in boats ranging in length from 18 feet or less carrying fewer than six passengers to custom-built dive vessels, 40 feet in length or longer, able to accommodate larger groups.

There are sixteen dive sites within the proposed sanctuary which are frequented by the tour operators surveyed. They make more than 4,256 trips per year to these sites (Table 3 ). Some of these tour operations do as much as 80-90 percent of their diving within the proposed sanctuary boundary. Many SCUBA divers conduct more than one dive during their stay. Two tank dives and multi-dive packages are becoming increasingly popular. More than 26,400 diver visits were made to dive sites located within the proposed sanctuary in 1978.

The ledges at Little St. James Island, Cow and Calf Rocks and the West Cove of Buck Island are the three most popular sites visited, with more than 1,028 combined diver visits each year (Table 3 ). These reefal communities provide excellent coral sea scapes for a variety of underwater activities. They are lush coral formations and include many species of corals. Common to the area are the following corals: elkhorn (Acropora palmata), staghorn (Acropora cervicornis), brain (Diploria), finger coral (Porites porites), and a variety of gorgonians and sponges. These coral communities provide an excellent habitat for many reef fish including: angel fish, butterfly fish, gobies, wrasses, parrotfishes, puffers, porcupine fish, baracuda, basslets, snappers, and damsel fish (see Appendix C for a complete listing of reef fish found in the proposed sanctuary.)

The ledges at St. James are precipitous cliffs that drop to 35 feet. Sea turtles have often been sited in the area. The ledges serve as refuges and resting places for many of the turtle species found in the area. Westend Bay on the south side of Buck Island has very large boulders which vary in heights from 10 to 15 feet. These boulders create an exciting underwater experience for divers and snorklers. The West Cove of Buck Island contains the recently relocated Cortensar Senior. The engine room, crew quarters, galley and the wheel house are intact making the ship an interesting dive experience in clear waters. The cove itself contains an extensive coral community and the bare rocks are encrusted with 1 impet mollusks and encrusting calcareous algae. A few large elkhorn coral grow on or near the rock substrates. Cow and Calf Rocks, located in the open waters of the proposal area, are coral caves that form corridors that allow the diver to go through several enclosed areas. A varitey of cave dwelling marine animals can be seen in this area. The popularity of these areas is increasing, Table 3 provides information on the number of visits by tour operators.

The Socio-Economic Survey reported that nearly 20 percent of the 52,000 diver days spent in all the Virgin Islands were involved in non-consumptive activities within $T-2$. The total recreational diving use of sanctuary waters 
TABLE 3

DIVE SITES WITHIN THE PROPOSED SANCTUARY

FREQUENCY OF TRIPS/DIVER VISITS

NUMBER OF TRIPS

SITE YEAR

NUMBER OF DIVER VISITS YEAR

Buck Island

1. West Cove

660

4,104

2. C. North

168

1,344

3. D. Capella Island

384

2,136

4. Cabrita Point

24

96

5. Cow \& Calf

792

4,032

6. Dog Island-Dog Rocks

552

2,520

Great St. James

7. Christmas Cove

48

144

8. Fish Cay

252

768

9. C. Caridad

24

96

10. East Cove

72

288

11. Great Bay

24

96

Little St. James

12. Ledges

912

4,200

13. South

132

720

14. Nazareth Bay

780

3,096

15. Packet Rocks

420

2,532

16. Scott Beach

12

240

TOTAL:

5,256

26,412 
could be as high as 60,000 diver days annually. Less than 2 percent of this activity involved harvesting of sanctuary resources.

Spearfishing is no longer widely practiced in the proposed sanctuary area. Areas like Cabrita Point and Packet Rock, which were popular spearfishing grounds less than a decade ago, are seldom visited today because other areas are more desirous. Currently, spearfishing occurs off Dog Island, Cow and Calf and Little St. James (V.I. Underwater Sports Association). 


\section{Commercial Fishing}

The Virgin Islands commercial fishery is a small scale artisinal fishery using boats that are generally less than 25 feet in length. Nearly 90 percent of the 161 St. Thomas - St. John fishermen utilize West Indian fish traps to catch a variety of species (Sylvester and Damman, 1976).

West Indian fish traps are the basic fishing gear used in the Virgin Islands and their use is considered a traditional fishing method in the Caribbean. The use of fish traps in the Caribbean is unlike that experienced in the Florida Keys where their general acceptance started in 1976-1977. Research in the history of fishing technology (Richard Price, Carribean Fishing and Fishermen: A Historical Sketch) reveals that fish traps (fish pots) were first used by the Carib Indians in the seventeenth century and used by African slaves during the eighteenth century. The method has undergone little change. Fish traps today reflect the basic design of those used by the African slave. Traps are made of wire mesh enclosures (chicken wire) supported by a frame of mangrove or other local galvanized wire mesh. The two-entrance rectangular wire and mangrove trap is very popular in the Virgin Islands. The traps used in Florida are constructed of vinyl-covered welded wire mesh, usually have opennings of $1^{\prime \prime} \times 2^{\prime \prime}$, or larger and typically have overall dimensions of $3^{\prime} \times 6^{\prime} \times 3^{\prime}$. The typical fish trap has a base area of 18 square feet. The typical commercial fisherman sets 20-100 traps and only selected species of fish are taken for commercial use. The rest are considered incidental by catch (Draft Environmental Impact Statement for the Proposed Looe Key National Marine Sanctuary, April 1980). The situation in the Florida Keys, with regard to wire fish traps, is significantly different from that which is experienced in the Virgin Islands, and adverse impacts associated with their use in Florida waters may not apply in the Caribbean.

The Virgin Islands Commercial Fisheries Act requires the 1.5 inch mesh size. 0lsen, et. al.(1978) in a study of mesh selectivity of West Indian fish traps showed that trap mesh size can be used to regulate incidental small fish mortality. It was found that the 1 inch hexagonal mesh caught 18 times more small fish. The 1 inch by 2 inch mesh caught 10 times more small fish than the 1.5 inch mesh. The 1.5 inch mesh size, currently the minimum legal size used in the Virgin Islands, is above the mesh size used in the study which causes unnecessary mortality of small fish. In addition, the Caribbean Regional Fishery Management Council (CFMC) after surveying the available scientific information, is recommending a regulation requiring the 1.5 inch mesh minimum with escape panels.

01sen (Personal communication, 1980) stated that the number of fishermen in St. Thomas has remained relatively stable. In 1917 there were 65, 1935--102, $1968--134,1974$ and 1975--165, 1976-1977--172, 1977-1978--162, and 1978-1979-161. During the years 1977-1979 the average landings to commercial fishermen were as follows in the T-2 area:

$\begin{array}{lr}\text { Hook-1ine } & 37.3 \% \\ \text { Net Fishing } & 5.5 \% \\ \text { Lobster Trapping } & 11.9 \% \\ \text { Lobster Diving } & 23.1 \% \\ \text { Fish Trapping } & 17.2 \% \\ \text { Other } & 5.0 \%\end{array}$


Total landings for the years 1978-1979 were 1.7 million $1 \mathrm{bs}$. of fish and $122,000 \mathrm{lbs}$. of lobster. This fishery has evolved into an equilibrium with the resource in which 01sen et.al.(1975) estimates a total annual landing of around 1.6 million pounds. These landings approach the substainable yield levels for the shelf in general (CFMC, 1979).

The Commercial Fishing Industry report conducted for the preparation of the DEIS revealed that commercial fishing within the proposed sanctuary boundary involved about 57 fishermen. Nearly 30 percent of their effort is directed towards harvesting the considerable bait resources (Harengula sp. and Anchoa sp.). Another 28 percent of the commercial fishery effort is based on the use of West Indian fish traps. Fish traps yield about five pounds of fish for each three day set. There are approximately 15 trap fishermen setting an average of 13 traps each (185 total traps each 3-day) in the proposed sanctuary waters. Handlining for bottom fish comprises about 23 percent of the effort and harvests 26,000 pounds annually. Lobster and other shellfish harvested by both traps $(11,520$ lbs) and diving (27,700 1bs) represents the other major harvest of the resources. The total commercial harvest from sanctuary waters is about 71,000 pounds and has a current value of around $\$ 330,000$ (Table 4). 
Table 4.

Annual recreational and commercial fishery landings from within the waters of the proposed St. Thomas marine sanctuary. Recreational figures are from 01 sen (1979) and include the entire DCCA reporting area T-2. Commercial landings were estimated from a survey of 36 of the 50 commercial fishermen who utilize the sanctuary. Landings were adjusted to a population of 50 fishermen.

\begin{tabular}{|c|c|c|c|c|c|c|}
\hline METHOD & Species Group & $\begin{array}{l}\text { Commercial } 2 \\
\text { Landings } \\
\text { (1bs) }\end{array}$ & $\begin{array}{l}\text { Recreational } \\
\text { Landings } \\
\text { (lbs) }\end{array}$ & $\begin{array}{l}3 \text { Total } \\
\text { (1 bs) }\end{array}$ & $\begin{array}{l}\text { Value } \\
(\$ / 1 b)\end{array}$ & $\begin{array}{l}\text { Total } \\
\text { Value (\$) }\end{array}$ \\
\hline Trolling & Pelagic Fish & 2,340 & $\angle 3,180$ & 25,520 & $\$ 1.85$ & $\$ 47,212$ \\
\hline $\begin{array}{l}\text { Bottom } \\
\text { Fishing }\end{array}$ & Reef Fish & 26,300 & 13,820 & 111,320 & $\$ 1.85$ & $\$ 205,942$ \\
\hline Traps & Reef Fish & 71,200 & & & & \\
\hline $\begin{array}{l}\text { Spear } \\
\text { Fishing }\end{array}$ & $\begin{array}{l}\text { Pelagic and } \\
\text { Reef Fish }\end{array}$ & & 26,790 & 26,790 & $\$ 1.85$ & $\$ 49,561$ \\
\hline $\begin{array}{l}\text { Lobsters } \\
\text { Diving } \\
\text { Traps }\end{array}$ & $\frac{\text { Panulirus }}{\underline{\text { argus }}}$ & $\begin{array}{l}22,700 \\
11,520\end{array}$ & 15,580 & 49,800 & $\$ 4.00$ & $\$ 199,200$ \\
\hline Conch & $\frac{\text { Strombus }}{\text { gigas }}$ & 6,000 & 2,603 & 8,603 & $\$ 1.50$ & $\$ 12,904$ \\
\hline Whelks ${ }^{1}$ & $\frac{\text { Cittarium }}{\text { pica }}$ & 600 & 3,211 & 3,811 & $\$ 4.00$ & \\
\hline Total $\mathrm{Va}$ & & 330,600 & 184,200 & & & $\$ 514,800$ \\
\hline
\end{tabular}

1. Whelk landings reported totals have been deleted from tables.

2. Data from 1979 survey of 36 out of the 50 fishermen using sanctuary waters. Data adjusted to landings from all 50.

3. Data from 01 sen (1979) recreational survey (and includes all of Virgin Islands catch reported in area $T-2$. 


\section{Recreational Fishery}

The magnitude of the recreational effort was preliminarily documented in the Economic Survey. The information gathered indicated that over 110,000 person-days annually are spent in recreational activity in the Virgin Islands, with nearly 20 percent of that activity $(22,000$ person-days) being spent in the T-2 reporting area (Figure 6 ), which includes the proposed marine sanctuary. Approximately one-half of the effort is spent in fishing activities, and the remainder comprises such activities as snorkeling, underwater photography and other non-consumptive uses.

\section{Recreational Boating}

Recreational and charter boaters are major users of the waters of the proposed sanctuary as 987 boats (over 55 percent of the Virgin Islands recreational boating fleet) are located in St. Thomas. This includes a crewed charter boat fleet around 235 boats (Virgin Islands Charterboat League, personal communication). Nearly 44 percent of the 987 St. Thomas boats are based within sanctuary waters and another 15 percent are based in nearby Red Hook (01sen, 1979). Nearly 20 percent of the entire Virgin Islands fleet utilizes the Benner Bay Mangrove Lagoon area as a hurricane anchorage. Additionally, much of the Virgin Islands sailboat racing is based at St. Thomas Yacht Club facilities in Cowpet Bay. The race courses are generally located in the smooth waters of St. James Bay and throughout the sanctuary waters.

There is a limited amount of time series data available for the growth of boating in the Virgin Islands which can be used as a basis for an analysis of future boating use potential in sanctuary waters. Boats which were anchored, moored and tied up at the docks were counted from a series of ariel photographs taken during the years 1947 to 1979. The counts were taken for the anchorages of the sanctuary. The growth in fleet size in these anchorages was then statistically fit to a curve to obtain the projections shown in Table 5. The carrying capacity of the various anchorages was estimated from the aerial photographs to be around 1700 boats (Table 5). Carrying capacity was defined simply as the number of additional boats which could be anchored or moored at the existing anchorages and areas containing additional development possibilities. This is not necessarily the desired carrying capacity for the sanctuary. 
Table 5 Use of the major St. Thomas anchorages as counted from areal photographs from 1947 to 1979. Carrying capacities have also been estimated from these photographs.

\begin{tabular}{|c|c|c|c|c|c|c|c|}
\hline ANCHORAGE & 1947 & 1954 & 1965 & 1971 & 1972 & 1979 & Capacity ${ }^{1}$ \\
\hline Red Hook/Vessup Bay & 1 & 10 & 22 & 55 & 72 & 171 & 300 \\
\hline Cowpet Bay & 1 & 0 & 4 & 29 & 35 & 54 & 100 \\
\hline Benner Bay & 0 & 0 & 25 & 73 & 145 & 175 & 200 \\
\hline False Entrance & 0 & 0 & 0 & 1 & 2 & 11 & 20 \\
\hline Christmas Cove & 0 & 0 & 0 & 9 & 0 & 2 & 50 \\
\hline Charlotte Amalie & 18 & 31 & 120 & 197 & 205 & 367 & 700 \\
\hline Total & 20 & 41 & 171 & 364 & 387 & 780 & 1670 \\
\hline
\end{tabular}

The expanding demand can be estimated from an analysis of information furnished by various sources which was projected by time series analysis until the year 2000. A significant element in the analysis is missing in that no estimate of transient yachts is available. Basically the calculations involve several assumptions. These assumptions are:

1. The crewed charter fleet will continue to grow at the rate indicated by the period from 1970 until 1979.

2. The number of boats registered in the Virgin Islands will continue to grow at the observed rate based on the period from 1963 to the present, and that proportion of the fleet registered in St. Thomas (55 from 0lsen, 1979) will remain constant, as well as the proportion of the fleet which is either moored, anchored out, or at dockside (01sen 1979).

3. The bareboat fleet will increase at a rate of 5 percent per year.

The projections shown in Table 5 indicate the projected growth in each of the components (excluding transient yachts). Additionally, the analysis indicates that demand for mooring and other boat storage facilities in these anchorages can be expected to exceed the estimated carrying capacity of 1700 boats in the period between 1980 and 1985. Since there are a substantial number of transient boats already present, there is reason to suspect that overcrowding will occur very early in the period. 
The need for management action can clearly be seen given the growth in fleet size from the period 1947 until 1979. The data indicates that the current increases in fleet size, if allowed to continue unchecked, could bring the fleet size to over 10,000 boats within 20 years. This degree of over utilization could significantly impact the resources of the area.

Additional evidence of this expanding use can be seen in Table 6 which shows the results of a survey conducted of a number of crewed, bareboat, and day charter enterprises regarding their activities in 1978 and 1979. The 1979 results were adjusted for an entire year since the data included only 9 months at the time of the survey. The increases between these two years are apparent. Both crewed and bareboat operations doubled their volume in the period while the day charter companies experienced nearly a 30 percent increase. Nearly all of these operations utilize sanctuary water resources.

Table 6. Charter boat activity in 1978 and 1979 in the Virgin Islands.

\begin{tabular}{lcrrrrr} 
& & & \multicolumn{2}{c}{1978} & \multicolumn{2}{c}{1979} \\
TYPE & \# Surveyed & \# Boats & Trips & \# Persons & \# Trips & \# Person \\
\hline & & & & & & \\
BAREBOAT & 7 & 142 & 1,028 & 5,020 & 2,688 & 11,400 \\
DAY CHARTER & 7 & 98 & 5,250 & 26,294 & 6,747 & 36,280 \\
CREWED CHARTER & 1 & 206 & 2,060 & 8,240 & 4,120 & 16,480
\end{tabular}

\section{Commercial Navigation}

Sanctuary waters are transited by few vessels involved in commercial navigation. Ships using the primary trade route among Charlotte Amalie, Puerto Rico, and the mainland United States have no occasion to enter sanctuary waters. Of the more than 700 cruise ships which annually visit St. Thomas, only about 1 percent (7-10 smaller vessels) enter or leave through the passage between Buck Island/Capella Island and St. Thomas. The primary commercial vessel users of sanctuary waters are small, inter-island cargo vessels; passengercarrying ferry boats; and barges.

Cargo Vessels - The small, inter-island cargo vessels trade between St. Thomas and the other islands of the eastern Caribbean. These ships, which are powered by a combination of engine and sail, carry loads of tropical produce, construction material, personal effects, and other freight. Approximately 10 to 12 vessels are regularly engaged in this trade (estimate from the U.S. Customs), each making one round-trip per week, for a total of 502-624 roundtrips per year.

Although statistics are unavailable, observations indicate that much of this commercial traffic avoids using sanctuary waters, which are considered somewhat dangerous due to shallow reefs, rocks, and proximity to land. of those vessels which do transit the waters, almost all use the passage between Buck Island and St. Thomas. Those vessels going directly to the eastern Caribbean then exit sanctuary boundaries on an east or southeast 
course, passing south of Dog Rocks. The remainder, approximately 5-7 vessels per week, head northeast for St. John and/or the British Virgin Islands, transiting the waters between Jersey Bay and Great St. James and entering Pillsbury Sound through Current Cut.

Passenger Ferries -- Two ferries, the Native Son and the Bomba Charger, each with a carrying capacity of about 100 people, operate regularly between Charlotte Amalie Harbor and the British island of Tortola. Together the two ferries make 38 scheduled round trips per week $(2,184$ round trips annually), using a route that takes them directly through sanctuary waters from an entry point between Buck Island and Packet Rock through Current Cut and exiting the sanctuary at Cabrite Point. Two ferry boat operators on St. John occasionally schedule special charters between that island and St. Thomas using the same route.

Barge Traffic -- Barge traffic through sanctuary waters is infrequent. The V.I. Department of Public Works operates a water barge, making about 40 round trips annually between Charlotte Amalie and St. John. A private barge hauling sand from the British Virgin Islands to St. Thomas makes the same number of trips. These barges enter and leave Pillsbury Sound by a route south of Dog Rocks.

\section{Research}

Given the rich variety of marine resources found in sanctuary waters, their importance to the overall resource base of the Virgin Islands, and their close proximity to land, it is hardly surprising that a considerable amount of marine research has been carried out in the proposed sanctuary area.

The first survey of the shoreline and water depths was done in 1851 by the British Admiralty. Offshore reefs were charted in 1924 by the U.S. Coast and Geodetic Survey and again in 1972-1973 by the National Ocean Survey.

Scientific research increased in the late 1960 's when several environmental impact studies (McNulty, Robertson and Horton, 1968; Tabb and Michael, 1968; Michel, 1970) were carried out in consequence of a proposal to construct a jet port in the Mangrove Lagoon. Since then the Government of the Virgin Islands has sponsored a number of studies of the dynamics of the Mangrove Lagoon ecosystem, fisheries, lobsters, wildlife, and the flora and fauna of offshore islands and cays.

In addition, research stations have been located in the area of the sanctuary. Dr. John Lilly conducted his first experiments on dolphin communication at a specially constructed laboratory at Nazareth Bay. This laboratory was later used for research on sharks and turtles by staff members of the Caribbean Research Institute (CRI). CRI also established a small field station laboratory at Benner Bay, from which it carried out research on the Mangrove Lagoon, fisheries, lobster, and ciguatera. Part of this station was later taken over by DCCA and now serves as headquarters for the research, monitoring, and enforcement activities of its Bureau of Fish and Wildlife. In the 1960's, a small lab facility was established on 
Buck Island by General Electric for the purpose of studying human physiology under weightless conditions for NASA.

The following research and monitoring activities are currently underway in sanctuary waters;

- Bureau of Fish and Wildlife (DCCA) -- West Indian topshell (whelk and conch) study under a National Marine Fisheries Service (NMFS) grant; a catch-per-unit effort fishery study under a NMFS grant; dove breeding, migration and feeding study under a U.S. Fish and Wildlife Service grant;

- Division of Natural Resources Management (DCCA)-- Water quality monitoring ( 9 field stations) under an Environmental Protection Agency (EPA) grant;

- Caribbean Research Institute (College of the Virgin Islands) study of the movements of whales and sea turtles under funding by CRI; completion of an environmental impact assessment for Long Point under a private contract.

\section{Dredge and Fill}

The sanctuary has not been the site of any major dredge or fill activity. In the Mangrove Lagoon, the area between the mainland and Patricia Cay was dredged to make a small beach on the northside of Long Point. Artificial beaches were also created at Cowpet using sand from Cowpet Bay and at Secret Harbor using sand taken from Nazareth Bay. Some 11 legal small scale dredging has taken place in and around Benner Bay. All of this dredge and fill activity took place in the 1960s or early 1970s. A small pier is also being considered for the west coast of Great St. James.

\section{Adjacent Land Use}

Shoreline development and use is rather extensive in certain areas such as Benner Bay because of the recreational and aesthetic values of the area. Shoreline use falls into the following categories:

- Resort and residential development

- Commercial and private docks and ancillary uses

- Government operations

Secret Harbor hotel, a small unit beach club hotel is located at Nazareth Bay by Cabrite Point. Condominiums are located at Secret Harbor and Cowpet Bay. A condominium complex is also under construction at Cabrite Hill, which borders the sanctuary on the north side of Great Bay. A few private residences are found on the western side of Benner Bay and on the cliffs between Compass Point and Cowpet Bay.

Commercial docks are concentrated east of the Mangrove Lagoon area between Turpentine Run and Benner Bay. There are five major operations for small 
power and sailing vessels and several smaller concerns with approximately 142 docks spaces.

A number of privately-owned small docks are located between Turpentine Run and Benner Bay. Private docks can also be found at Secret Harbor, Cowpet Bay, and Great Bay. For the most part, one or two vessels tie up at these docks at a time. In addition the St. Thomas Yacht Club, located at Cowpet Bay maintains 70 moorings.

The local government owns nearly all the land from Long Point to Turpentine Run, which borders on the Mangrove Lagoon. Most of this land is currently not in use and is designated as an area of particular concern under the Virgin Islands Coastal Zone Program. However, the Virgin Islands Government operates a municipal sanctuary landfill in the area adjacent to the sanctuary. Plans by the Virgin Islands Government, the U.S. Environmental Protection Agency, and the U.S. Army Corps of Engineers to construct a high temperature incinerator/solid waste recovering operation nearby on Long Point will phase down and eventually eliminate the landfill operation. 
Many persons participated in the preparation of this document. A major portion of the environmental analysis was performed under cooperative agreement with the Virgin Islands Government, Department of Conservation \& Cultural Affairs. A Marine Sanctuary Advi sory Board was established by the Department to assist in the preparation of this document. NOAA would like to express gratitude to the Marine Sanctuary Advisory Board and Dick Avery for their technical assistance and the many others who have been interested in the proposal.

Members of the St. Thomas Marine Sanctuary Advisory Board

$\begin{array}{ll}\text { Dave Friendenbaugh } & \text { Dive Tour Operator } \\ \text { Dusty Pearsall } & \text { Power Boat Association } \\ \text { John Jouett } & \text { Member, St. Thomas Yacht Club } \\ \text { Mark Marin } & \text { St. Thomas V.I. Underwater Sports Association } \\ \text { Peter LaPlace } & \text { Commercial Fisherman } \\ \text { John T. Olive } & \text { Commercial Fisherman } \\ \text { Danny Garces } & \text { Commercial Fisherman } \\ \text { Shiela Ross } & \text { Sailing } \\ \text { Rosemary Gailiber } & \text { President, V.I. Conservation Society } \\ \text { Mary Innis } & \text { Legislative Assistant }\end{array}$


Virgin Islands Department of Conservation Cultural Affairs

Darlan Brin

Dr. David 01 son

Jerry McCrain

Cheryl Coodley

Frank Gary
Commissioner

Director, Division of Fish and Wildlife Environmental Specialist

Attorney

Attorney

Office of Coastal Zone Management Sanctuary Program Office

Dallas Miner

Dr. Nancy Foster

Edward Lindel of

Annie Hillary

John Milholland
Director

Deputy Director

Gulf \& Caribbean Project Manaqer

Program Specialist

Attorney 
Adams, John B., L. Gerhard, J. Ogden and Jan Bowden. 1975. Potential National Landmarks - United States Virgin Islands. West Indies Laboratory. Fairleigh Dickenson University, St. Croix, U.S. Virgin Islands.

Beller, William. 1970. The United States Virgin Islands and the Sea. Office of the Lieutenant Governor, St. Thomas, U.S. Virgin Islands

Bowden, Martyn J. 1970. Climate, Water Balance and Climatic Change in the Northwest Virgin Islands. Caribbean Research Institute, College of the Virgin Islands, St. Thomas, U.S. Virgin Islands.

Blake, Patricia. 1979. Native of Buck Island Returns to Birthplace. Daily News, St. Thomas, U.S. Virgin Islands, January 2, 1979.

Caribbean Fisheries Management Council. 1979. Fisheries Management Plan for Spiny Lobster Panulirus argus.

Coleman, S., J.A. La Place, J. Mudre and K. Turbe. 1979. Fishery Statistics of the Virgin Islands, 1977-1978. DCCA report for N.M.F.S. P.L. 88-309 Program, 38 pp., St. Thomas, U.S. Virgin Islands.

De Booy, T. and J.T. Faris. 1918. The Virgin Islands, Our New Posessions. J.B. Lippincott Co., Phil., Pa.

Grigg, D.I., R.P. Van Eepopel and R.W. Brody. 1971. Water Quality and Environmental Status of Benner Bay - Mangrove Lagoon, St. Thomas. Caribbean Research Institute, College of the Virgin Islands. Water Pollution Report, No. 10.

Holmes, C.W. 1978. Virgin Islands Sand Resource Study. United States U.S.G.S. Open File Report \#78-919.

Hubbard, D.K. 1979. A Summary of Physical Factors Affecting Sediment Transport in the Proposed St. Thomas Marine Sanctuary. A Report to DCCA, Govenment of the Virgin Islands.

Jaap, W., and D.A. 01sen. 1979. (in progress) Depth Profile of Scleratinian Coral Diversity in Lucaya, Grand Bahama.

Little, E.L., and F.H. Wadsworth. 1964. Common Trees of Puerto Rico and the Virgin Islands Agriculture Handbook No. 249. Forest Service, USDA.

Lopez, P.F. 1978. Outdoor Recreation in the Virgin Islands. Report for the Department of Conservation and Cultural Affairs, St. Thomas, U.S. Virgin Islands. 
MacLean, W.P. 1979. Cabrite Point Development: Impacts on Non-Marine Communities. Environmental Impact Statement, St. Thomas, V.I.

MC Crain, G.R. 1979. Cabrite Point Development: Effects of Potential Construction Site Erosion on the Marine Environment. Environmental Impact Assessment, St. Thomas, V.I.

Mc Nulty, J.K., W.B. Robertson, and B.F. Horton. 1968. Departmental Study Team Report and Recommendation on Proposed New Jet Airport, St. Thomas U.S. V.I., 34 pp.

Michel, John F. 1970. A Study of the Hydrodynamic Effects of the Proposed Airport at Long Beach Point, St. Thomas, Virgin Islands. A Report to the Virgin Islands Port Authority, St. Thomas, U.S. V.I.

Nichols, Mand and E. Towle. 1977. Water, Sediments and Ecology of the Mangrove Lagoon and Benner Bay, St. Thomas. Island Resource Foundation, St. Thomas V.I.

01sen, D.A. 1977. The Ecology and Diversity of Fishes in Two Virgin Islands Mangrove Lagoons. Island Resource Foundation, St. Thomas, V.I. Occassional Paper \#27.

01sen, D.A., A.E. Dammann, and J.A. La Place. 1975. Analys is of Catch Data for the Virgin Islands (1974-75) V.I. DCCA, PL 88-309 Report, $16 \mathrm{pp}$.

01sen, D.A. and M.0. Sheen. 1975. A Comparison of the PRINUL and Hydrolab Coral Reef Systems. Hydrolab Journal 3 (1) 108-113.

01sen, D.A. 1979. Socio-Economic Survey of Recreational Boating and Fishing in the U.S. Virgin Islands. National Marine Fisheries Service, $76 \mathrm{pp}$.

01sen, D.A., A.E. Dammann, and J.A. La Place. 1978. Portunus spinamanus Latrielle, A Portunid Crab with Resource Potential in the U.S. Virgin Islands. Marine Fisheries Review, Vol. 40, No. 7.

Tabb, D.C. and J.F. Miche1. 1968. A Study of the Biological and Coastal Engineering Aspects of the Proposed Jet Airport at Jersey Bay, St. Thomas U.S. Virgin Islands. Institute of Marine Sciences University of Miami.

Towle, E.L., D.A. 01sen, and A.R. Teytaud. 1978. Report on Sea Turtle Nesting, Sighting, Eggs and Hatching for 1978 in the U.S. Virgin Islands. Island Resources Foundation Report to NOAA/N.M.F.S.

Tyson, George F. Jr. 1977. Powder, Profits and Privateers: A Documentary History of the Virgin Islands During the Era of the American Revolution. Island Resources Foundation, St. Thomas U.S. V.I.

Van Eepoe1, R.P., W. Owen, and A.E. Dammann. 1971. Notes on Some Oceanographic Marine Factors in the U.S. Virgin Islands. Caribbean Research Institute. St. Thomas, U.S. V.I. 
Virgin Island Resource Conservation and Development Council. 1973. U.S. Virgin Islands Resource Conservation and Development Project Plan. V.I. Department of Agriculture.

Virgin Islands Planning Office. 1976. Virgin Islands Coastal Zone Management: The Marine Environment, 190 pp., St. Thomas, U.S. Virgin Islands.

Wells, J.M. and D.A. 01 sen. 1973. Oxygen Balance in Tropical Benthic Communities Proc X Ann. Conf. Is. Mar. Lab., Caribb. J. Sci.

Westergaard, W. 1917. The Danish West Indies: 1617-1917.

Willis, Jean L. 1967. The Trade Between North America and the Danish West Indies, 1756-1807, with Special Reference to St. Croix. Unpublished Ph.D dissertation, Columbia, Univ.

Zube, E.H. 1968. The Virgin Islands: Selected Resources of the United States Virgin Islands. U.S. Dept. of Interior. 

APPENDIX A

Draft Designation Document

Designation of the St. Thomas National Marine Sanctuary

Preamble

Under the authority of the Marine Protection, Research and Sanctuaries Act of 1972, P.L. 92-532, (the Act) certain waters off St. Thomas, U. S. Virgin Islands, are hereby designated a Marine Sanctuary for the purposes of preserving and protecting their unique and fragile ecological and recreational resources.

Article 1. Effect of Designation

The designation of the St. Thomas National Marine Sanctuary (the Sanctuary), described in Article 2, establishes the basis for cooperative management of the area by the Virgin Islands and the National Oceanic and Atmospheric Administration (NOAA).

Within the area designated as the Sanctuary described in Article 2, the Act authorizes the promulgation of such regulations as are reasonable and necessary to protect the values of the Sanctuary.

On , 1981, the Virgin Islands issued regulations controlling those activities which may threaten the values of the Sanctuary, all of which are located within territorial waters. NOAA has determined that these regulations are fully adequate to protect the values of the Sanctuary. Therefore, this Designation only authorizes NOAA to adopt these regulations as set forth in Article 5 and to issue additional regulations only in the event that an activity is found not to be subject to the jurisdiction of the Virgin Islands.

Article 4 of the Designation lists those activities which may require regulation, but the listing of an activity does not by itself prohibit or restrict it. Restrictions or prohibitions may be accomplished only through regulations, and activities not listed in Article 4 may be regulated only after amending Article 4, or in cases of emergency, as specified in Article 4, Section 2 .

Article 2. Description of the Area

The Sanctuary consists of an area of approximately 9.27 square nautical miles of the waters of the territorial sea of the U. S. Virgin Islands located off southeast St. Thomas. The precise boundaries are defined by regulation.

Article 3. Characteristics of the Area that Give it Particular Value

The Sanctuary contains hundreds of species of marine organisms, including Caribbean corals, hawkbill and leatherback turtles, significant mangrove stands, and diverse tropical faunal and floral communities. The area provides exceptional recreational experiences and scientific research opportunities and generally has unique value as an ecological, recreational, and esthetic resource. 
Article 4. Scope of Regulation

Section 1. Activities Subject to Regulation. In order to protect the distinctive values of the Sanctuary, the following activities may be regulated within the Sanctuary to the extent necessary to ensure the protection and preservation of the coral and other marine features and the ecological, recreational, and esthetic value of the area:

(a) Removing, breaking or otherwise harming coral or other bottom formations or plants, except incidental to other fishing operations.

(b) Operations of vessels except fishing vessels and anchoring by all vessels.

(c) Construction on, dredging of, or altering of the seabed.

(d) Discharging or depositing any substance or object.

(e) Using poisons, electric charges or explosives.

(f) All activities including fishing along designated underwater trails.

(g) Removing or harming cultural or historical resources.

(h) Removing or damaging navigation aids, markers, or fishing traps or gear.

(i) Activities affecting or likely to affect marine mammals, turtles or other endangered species.

Section 2. Emergency Regulations. Where essential to prevent immediate, serious and irreversible damage to the ecosystem of the Sanctuary, activities other than those listed in Section 1 of this Article may be regulated within the limits of the Act on an emergency basis for a period not to exceed 120 days, during which an appropriate amendment of this Article may be proposed in accordance with the procedures specified in Article 6. In order to invoke this section, the Secretary of Commerce must first make a finding of emergency, which determination shall be transmitted in writing to the Virgin Islands.

Section 3. Consistency with International Law. The regulations governing the activities listed in Section 4 of this Article will be applied to foreign flag vessels and persons not citizens of the United States only to the extent consistent with recognized principals of international law or as otherwise authorized by international agreement.

\section{Article 5. Relation to Other Regulatory Programs}

Section 1. Virgin Islands Program

(a) The Virgin Islands' regulations described in Article 1 effectively protect the resources of the Sanctuary and shall constitute the primary regulatory regime for it. NOAA may adopt the Virgin Islands' regulations under the following conditions: 
(1) No alteration or modification of any Sanctuary regulation shall become effective without the written concurrence of both the Virgin Islands and NOAA; and

(2) The Virgin Islands shall be responsibile for enforcing all of the Sanctuary regulations to ensure protection for the values of the Sanctuary. NOAA will engage in enforcement activities only if requested by the Virgin Islands or if there has been a significant failure to provide adequate enforcement as determined under this section.

(b) Where the Virgin Islands shall propose any alteration or modification of the regulations described in Article 1, such al teration or modification shall be submitted to NOAA for simultaneous proposal in the Federal Register. Such alteration or modification shall be finally adopted unless, based on the comments received on the Federal Register proposal and after consultation with the Virgin Islands, NOAA cannot determine that the regulations with the proposed amendments provide reasonable and necessary protection for the values of the Sanctuary.

(c) Should NOAA preliminarily determine that there has been a significant failure to provide adequate enforcement, it shall notify the Virgin Islands of this deficiency and suggest appropriate remedial action. If, after consultation, NOAA and the Virgin Islands are unable to agree either that a deficiency exists or on appropriate remedial action, NOAA may issue a final determination in writing specifying the deficiency and the appropriate action together with the reasons therefore. No less than 60 days prior to issuing a final determination that calls for NOAA to take enforcement action, NOAA shall submit the proposed determination to the Governor of the Virgin Islands. If the Governor finds that NOAA enforcement is unnecessary to protect the values of the Sanctuary NOAA shall give such finding presumptive weight in making its final determination.

Section 2. Fishing. The regulation of fishing is not authorized under Article 4 except with respect to the removal or damage of coral or other bottom formations (paragraph (a)), the use of certain techniques (paragraph (e)) and along underwater trails (paragraph (f)). In addition, fishing vessels may be regulated with respect to discharges (paragraph (d)) and anchoring (paragraph (b)).

Section 3. Defense Activities. The regulation of those activities listed in Article 4 shall not prohibit any activity conducted by the Department of Defense that is essential for national defense or because of emergency. Such activities shall be conducted consistently with such regulations to the maximum extent practicable. All other activities of the Department of Defense are subject to Article 4.

Article 6. Alterations to this Designation.

This Designation can be altered only in accordance with the same procedures by which it has been made, including public hearings, consultation with interested Federal and State agencies and approval by the Governor of the Virgin Islands and by the President of the United States. 
Article 7. Funding.

In the event that a reduction in the funds available to administer the Sanctuary necessitates a reduction in the level of enforcement provided by the Virgin Islands, the resulting reduced level of enforcement shall not, by itself, constitute a basis for finding a deficiency under Article 5, Section 1 .

\author{
[END OF DESIGNATION]
}


DRAFT NOAA REGULATIONS FOR THE ST. THOMAS NATIONAL MARINE SANCTUARY

PART 937 - THE ST. THOMAS NATIONAL MARINE SANCTUARY REGULATIONS

937.1 Authority.

937.2 Purpose.

937.3 Boundaries.

937.4 Regulated Activities.

937.5 Penalties for Commission of Prohibited Acts.

937.1 Authority.

The sanctuary has been designated by the Secretary of Commerce pursuant to the authority of section 302(a) of Title III of the Marine Protection, Research and Sanctuaries Act of 1972, 16 U.S.C. 1431-1434 (the Act). The following regulations are issued pursuant to the authorities of sections $302(f), 302(g)$ and 303 of the Act.

\subsection{Purpose.}

The purpose of designating the Sanctuary is to protect and preserve the diverse natural and cultural resources of the waters off southeast St. Thomas, U.S. Virgin Islands and to ensure the continued availability of the area for public educational purposes and as an ecological, research and recreational resource. This area contains the most significant stand of mangroves in the Virgin Islands, extensive coral reef communities, coral caves, and several shipwrecks that are important recreational dive sites. The area also supports juvenile and adult conch, lobster, and fish habitats, plus nesting and feeding areas for endangered turtle species. The area is adjacent to St. Thomas, U.S. Virgin Islands and is widely used by boaters, charter boat operators, dive boats, and recreational and commercial fishermen. Consequently, both present and potential levels of use may result in harm to the area in the absence of long term planning, research, monitoring and adequate protection.

\subsection{Boundaries.}

The Sanctuary consists of an area of 9.27 square nautical miles of the waters of the territorial sea of the U.S. Virgin Islands located off southeast St. Thomas. The precise boundaries are:

Beginning at the shoreline of Stalley Bay at Latitude $18^{\circ} 18^{\prime} 29^{\prime \prime}$ Longitude $64^{\circ} 52^{\prime} 49^{\prime \prime}$ to a point southwest of Packet Rock at Latitude $18^{\circ} 18^{\prime} 03^{\prime \prime}$ Longitude $64^{\circ} 53^{\prime} 36^{\prime \prime}$, to a point southwest of Buck Island at Latitude $18^{\circ} 16^{\prime} 26^{\prime \prime}$ Longitude $64^{\circ} 54^{\prime} 11^{\prime \prime}$, thence northeast to a point off Dog Rocks at Latitude $18^{\circ} 17^{\prime} 36^{\prime \prime}$ Longi tude $64^{\circ} 49^{\prime} 42^{\prime \prime}$, then to the shoreline of Cabrita Point at Latitude $18^{\circ} 19^{\prime} 36^{\prime \prime}$ Longitude $64^{\circ} 49^{\prime} 56^{\prime \prime}$.

937.4. Regulated Activities

All activities carried on in the Sanctuary are subject to all prohibitions, restrictions and conditions imposed by any other authority. 
Any violation of the restrictions, prohibitions, or conditions imposed by Section 912 of the Virgin Islands Coastal Zone Management Act and regulations issued pursuant thereto shall constitute a violation of these Federal regulations rendering the violator liable for the civil penalty described in section 937.5 in addition to any penalty perscribed by the Virgin Islands. The applicable Virgin Islands regulations are as follows:

\section{A. PROHIBITED ACTIVITIES}

Except as may be necessary for the national defense, in accordance with Article 5, section 2 of the Designation, or as may be necessary to respond to an emergency threatening life, property or the environment, the following activities are prohibited within the Sanctuary unless permitted by the Commissioner of the Virgin Islands Department of Conservation and Cultural Affairs in accordance with section B (of the Virgin Islands regulations, not reprinted here).

\section{Taking and Damaging Natural Resources}

a. No person shall break, cut, or similarly damage or destroy any coral, bottom formation or any marine plant, except dead shells. There shall be a presumption that any items listed in this paragraph found in the possession of a person within the sanctuary have been collected or removed from the sanctuary.

b. Only traditional fishing methods shall be permitted within the sanctuary. No person shall use poisons, electrical charges, explosives or similar methods to take any marine animal or plant.

\section{Operation of Vessels}

a. No person shall anchor on coral reefs or in any manner that damages coral or other natural or cultural resources. All practicable efforts shall be taken to drop anchors on sand flats, rock and rubble bottoms, and other areas without extensive coral formations. When anchoring dive boats, the first diver down shall inspect the anchor to ensure that it is placed off the corals and will not shift in such a way as to damage corals. No further diving is permitted until the anchor is placed in accordance with these requirements.

b. No person shall anchor in areas where mooring buoys have been placed by the Government of the Virgin Islands or NOAA.

c. No vessel under power shall approach closer than 200 feet to a fishing vessel or a vessel displaying a diving flag except at a maximum speed of three knots.

d. No vessel or person shall interfere with any fishing activity.

e. All vessels from which diving operations are being conducted shall fly, in a conspicuous manner, the international code flag alpha "A." 


\section{Alteration of the Seabed and Construction}

a. No person shall dredge, fill or otherwise alter the seabed in any manner nor construct any structure other than a navigation aid except as permitted by this section.

b. The following activities are allowed subject to the limitations and conditions imposed by the applicable permits and licenses issued under the Virgin Islands Coastal Zone Management Act, V.I.C. Chapter 21, Title 12, ( $V I C Z M A)$ :

1) Construction of piers, docks, moorings, and similar structures, except in the Mangrove Lagoon (defined as an area from Bovoni Cay west to the shoreline of St. Thomas);

2) Dredge and fill activities necessary for public service purposes, including but not limited to the burying and maintenance of cables and pipes; and

3 Channel dredging within the area of Benner Bay and Bovoni Passage (defined as an area from the northwest point of Bovoni Cay, northeast to Benner Bay and in Benner Bay from a line drawn from the northeast corner of Bovoni Cay south to the northwest point of Grotto Cay, north to Compass Point) provided such activity can be clearly demonstrated to be in the public interest.

\section{Discharging of Polluting Substances}

No person shall litter, deposit or discharge any materials or substances of any kind except:

a. Indigenous fish or fish parts. Guard standards.

b. Effluent from marine sanitation devices allowable under Coast

c. Municipal sewage from the existing outfall consistent with U.S. Environmental Protection Agency standards.

5. Underwater Trails

a. No person shall spearfish or fish at the underwater trails, except bait fishing.

b. No person shall mark, deface, or injure in anyway, or displace, remove, or tamper with underwater trails signs, markers or bouys.

6. Removing or Damaging Cultural Resources

No person shall remove, damage, or tamper with, any historical or cultural feature, including archaeological sites, historic sturctures, shipwrecks, and artifacts. 
7. Marine Mammals and Endangered Species

No person shall harass, disturb, harm or in any way injure any marine mammal or other species classified as endangered by the Federal or Virgin Islands Government.

8. Damage to Fish Traps

No person shall disturb, harm, or tamper with any legal fish gear, nets, traps, or pots.

937.5 Penalties for Commission of Prohibited Act

Section 303 of the Act authorizes the assessment of a civil penalty of not more that $\$ 50,000$ against any person subject to the jurisdiction of the United States for each violation of any regulation issued pursuant to the Act, and further authorizes a proceeding in rem Title 12 Virgin Islands Code Chapter 12 against any vessel used in violation of any such regulation. Procedures are outlined in Subpart D of Part 922 (15 CFR Part 922) of this chapter. Subpart $D$ is applicable to any instance of a violation of these regulations. 


\section{A. PROHIBITED ACTIVITIES}

Except as may be necessary for the national defense, in accordance with Article 5, section 2 of the Designation, or as may be necessary to respond to an emergency threatening life, property or the environment, the following activities are prohibited within the Sanctuary unless permitted by the Commissioner of the Virgin Islands Department of Conservation and Cultural Affairs in accordance with section $B$.

\section{Taking and Damaging Natural Resources}

a. No person shall break, cut, or similarly damage or destroy any coral, bottom formation or any marine plant except dead shells. There shall be a presumption that any items listed in this paragraph found in the possession of a person within the sanctuary have been collected or removed from the sanctuary.

b. Only traditional fishing methods shall be permitted within the sanctuary. No person shall use poisons, electrical charges, explosives or similar methods to take any marine animal or plant.

\section{Operation of Vessels}

a. No person shall anchor on coral reefs or in any manner that damages coral or other natural or cultural resources. All practicable efforts shall be taken to drop anchors on sand flats, rock and rubble bottoms, and other areas without extensive coral formations. When anchoring dive boats, the first diver down shall inspect the anchor to ensure that it is placed off the corals and will not shift in such a way as to damage corals. No further diving is permitted until the anchor is placed in accordance with these requirements.

b. No person shall anchor in areas where mooring buoys have been placed by the Government of the Virgin Islands or NOAA.

c. No vessel under power shall approach closer than 200 feet to a fishing vessel or a vessel displaying a diving flag except at a maximum speed of three knots.

d. No vessel or person shall interfere with any fishing activity.

e. All vessels from which diving operations are being conducted shall fly, in a conspicuous manner, the international code flag alpha "A."

\section{Alteration of the Seabed and Construction}

a. No person shall dredge, fill or otherwise alter the seabed in any manner nor construct any structure other than a navigation aid except as permitted by this section. 
b. The following activities are allowed subject to the limitations and conditions imposed by the applicable permits and licenses issued under the Virgin Islands Coastal Zone Management Act, V.I.C. Chapter 21, Title 12, (VICZMA):

i) Construction of piers, docks, moorings, and similar structures, except in the Mangroove Lagoon (defined as an area from Bovoni Cay west to the shoreline of St. Thomas);

ii) Dredge and fill activities necessary for public service purposes, including but not limited to the burying and maintenance of cables and pipes; and

iji) Channel dredging within the area of Benner Bay and Bovoni Passage (defined as an area from the northwest point of Bovoni Cay, northeast to Benner Bay and in Benner Bay from a line drawn from the northeast corner of Bovoni Cay south to the northwest point of Grotto Cay, north to Compass Point) provided such activity can be clearly demonstrated to be in the public interest.

\section{Discharging of Polluting Substances}

No person shall litter, deposit, or discharge any materials or substances of any kind except:

a. Indigenous fish or fish parts.

b. Effluent from marine sanitation devices allowable under Coast Guard standards.

c. Municipal sewage from the existing outfall consistent with U.S. Environmental Protection Agency standards.

5. Underwater Trails fishing.

1. No person shall spearfish or fish at underwater trails, except bait

2. No person shall mark, deface, or injure in anyway, or displace, remove, or tamper with underwater trails signs, markers or bouys.

\section{Removing or Damaging Cultural Resources}

No person shall remove, damage, or tamper with, any historical or cultural feature, including archeaological sites, historic structures, shipwrecks, and artifacts.

\section{Marine Mammals and Endangered Species}

No person shall harass, disturb, harm or in any way injure any marine mammal or other species classified as endangered by the Federal or Virgin Islands Government. 


\section{Damage to Fish Traps}

No person shall disturb, harm, or tamper with any legal fish gear, nets, traps, or pots.

\section{B. PERMIT PROCEDURES AND CRITERIA}

1. Permits for those activities allowed under section A.3.b. shall be issued in accordance with the procedures and criteria set forth in sections 910 of the VICZMA.

2. Permits for those activities prohibited by section A may be issued by the Commissioner of the Virgin Islands Department of Conservation and Cultural Affairs in accordance with the Virgin Islands (VICZMA) and with this section provided such activity is either (1) research related to the resources of the sanctuary or (2) to preserve and protect the recreational and educational value of the sanctuary or (3) for salvage or recovery operations.

a. In addition to any other requirements under Section 912 in considering whether to grant a permit, the Commissioner shall evaluate such matters as (1) the general professional and financial responsibility of the applicant; (2) the appropriateness of the methods envisioned to the purpose(s) of the activity; (3) the extent to which the conduct of any permitted activity may diminish of enhance the value of the Sanctuary as an ecological, recreational, educational or scientific resource; and the end value of the activity satifies the criteria of this section; (5) such other matters as deemed appropriate.

b. At least 30 days prior to issuing any permit under this section, the Commissioner shall notify the Assistant Administrator for Coastal Zone Management, National Oceanic and Atmospheric Administration, 3300 Whitehaven Street, Washington, D.C. 20035, of the application and shall include a description of all activities proposed, the equipment, methods and personnel involved (particulary describing relevant experience) and a timetable for completion of the proposed activity.

c. The Commissioner may seek and consider the views of any other person or entity, within or outside of the Federal Government.

d. NOAA Assistant Administrator for Coastal Zone Management or designated representative may observe any permitted activity and/or require the submission of one or more reports of the status or progress of such activity.

e. A11 information obtained pursuant to a permit issued under this section shall be made available to the public. 

APPENDIX B -- Analysis of Existing Federal and Territorial Statutes

I. TERRITORIAL AUTHORITIES

A. Introduction

Pursuant to an act of 1974 (48 USC 1301 et. seq.) as recently amended by P. L. 96-205, the Virgin Island's jurisdiction extends $3 \mathrm{nmi}(5.6 \mathrm{~km})$ seaward from near high tide and includes the entire area under consideration. Its authorities range in scope from broad management programs such as the Virgin Islands Coastal Zone Management Act to laws directed at controlling more specific threats or protecting more specific resources.

\section{B. Resource Protection}

1. The Virgin Island Coastal Zone Management Act of 1978 (VICZMA) 12VIC $\$ 901$, et. seg.

The VICZMA establishes a comprehensive set of policies to manage all development activities and conserve and protect valuable natural resources throughout the coastal zone. The coastal zone extends to the offshore islands and cays and to the limit of the territorial sea thus encompassing the entire area of the proposed sanctuary.

Several of the management policies established by the VICZMA address concerns relevant to the consideration of a marine sanctuary:

1) to conserve significant natural areas for their contribution to marine productivity and value as habitats for endangered species and other wildlife;

2) to protect complexes of marine resource systems of unique productivity, including reef, marine meadows, salt ponds, mangroves and other natural systems, and assure that activities in or adjacent to such complexes are designed and carried out so as to minimize adverse effects on the marine productivity, habitat value, storm buffering capabilities, and water quality of the entire complex;

3) to preserve and protect the environments of offshore islands and cays;

4) to encourage fishing and carefully monitored mariculture and, to the maximum extent feasible, to protect local fishing activities from encroachment by non-related development;

5) to assure that dredging and filling of submerged lands is clearly in the public interest... To these ends (such activity may be permitted) only where there are no feasible, less environmentally damaging al ternatives...

6) to assure that development in areas adjacent to environmentally sensitive areas is sited and designed to prevent impacts which would significantly degrade such areas;

7) to protect and enhance the characteristics of the coastal 

areas most valued as amenities; and
8) to protect and enhance public coastal recreational uses. 12 VIC $\$ 906$.

The principal management mechanism is a permit system whereby any significant development activity requires a permit from the appropriate Coastal Committee (one is established for each island). To obtain a permit, the applicant must conduct an investigation of the prevailing environmental conditions of the site. The investigation must clearly indicate the probable effects, including adverse effects, to the environment of the proposed project. The Committee must then find that the development is consistent with the goals and policies of the Act including the above and that the development incorporates, to the maximum extent feasible, measures designed to mitigate adverse environmental impacts.

In addition, if the proposed activity is on "Trustland," or involves altering submerged or filled lands which are included within the sanctuary, the governor and the legislature must approve the permit after making the further findings that:

1) the grant of the permit will be in the public interest;

2) the development will enhance or result in minimal damage to the environment;

3) there is no reasonable feasible alternative to the comtemplated use which would reduce any adverse envirommental impact; and

4) the project will be adequately supervised to avoid more than minimum damage to the environment.

Section 910 of the VICZMA authorizes the promulgation of regulations to further implement its broad, comprehensive goals, objectives and policies and provide more specific protection for the marine resources of the Virgin Islands. While issuance of these regulations could address more specifically such concerns as coral collection and dive site management throughout the proposed sanctuary area, the Virgin Islands necessarily has focussed on developing regulations for the 18 Areas of Particular Concern (APC) established by the VICZMA and are likely to continue to focus on these areas given the basic level of finding available. Only the Benner Bay/Mangrove Lagoon area/ approximately $1 / 5$ of the proposed sanctuary is an APC.

\section{Commercial Fishing Act (12 VIC 301)}

It is the purpose of the Commercial Fishing Act (CFA) to preserve, manage and protect the fishery resources, to regulate fishing, and to secure the development of fisheries in waters of the Virgin Islands.

The Act provides a scheme whereby any person engaging in fishing (commercial or sport) must obtain a license, and all vessels or other fishing devices must be registered or certified. The DCCA is authorized to issue rules and regulations including: establishing closed seasons; regulating size or quantity limits for any species of marine flora or fauna; regulating the mesh size for nets and the design of traps, pots, nets, seines, and other devices 
for fishing; and regulating and prohibiting fishing for such times as may be necessary to protect the resource.

In addition to providing for regulation by DCCA, the CFA itself regulates the taking of marine turtles and spiny lobsters, and the use of certain types of gear and methods (See Table 7 ).

As part of the effort to make regulations governing fishery resources consistent with regulations proposed by the Caribbean Fishery Management Council (see Section 2, Federal Authorities, of this Appendix), the Virgin Islands Fishery Advisory Committee (FAC) has recommended certain changes to the CFA and regulations. Table 7 shows the existing regulations and those proposed by FAC. 


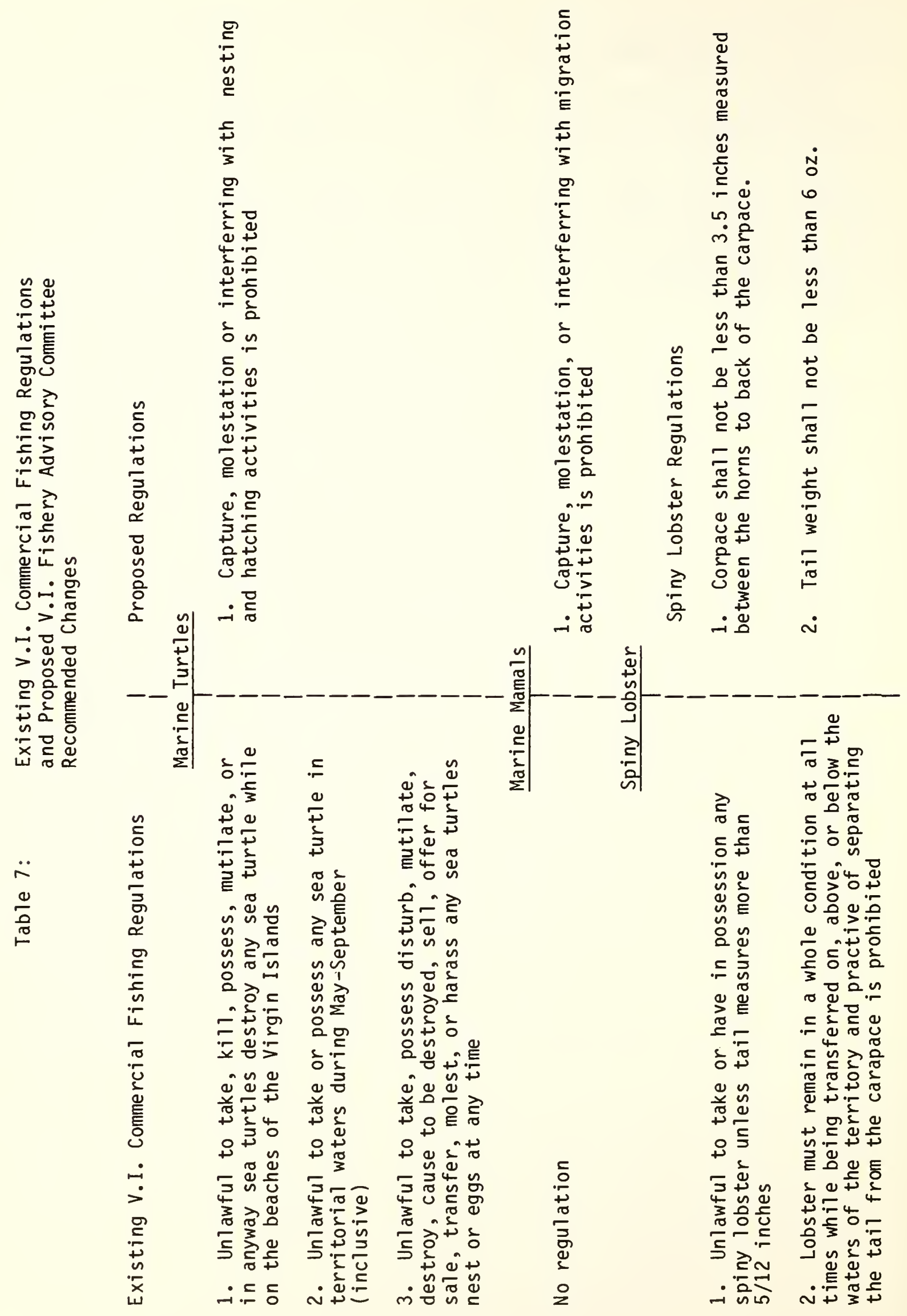




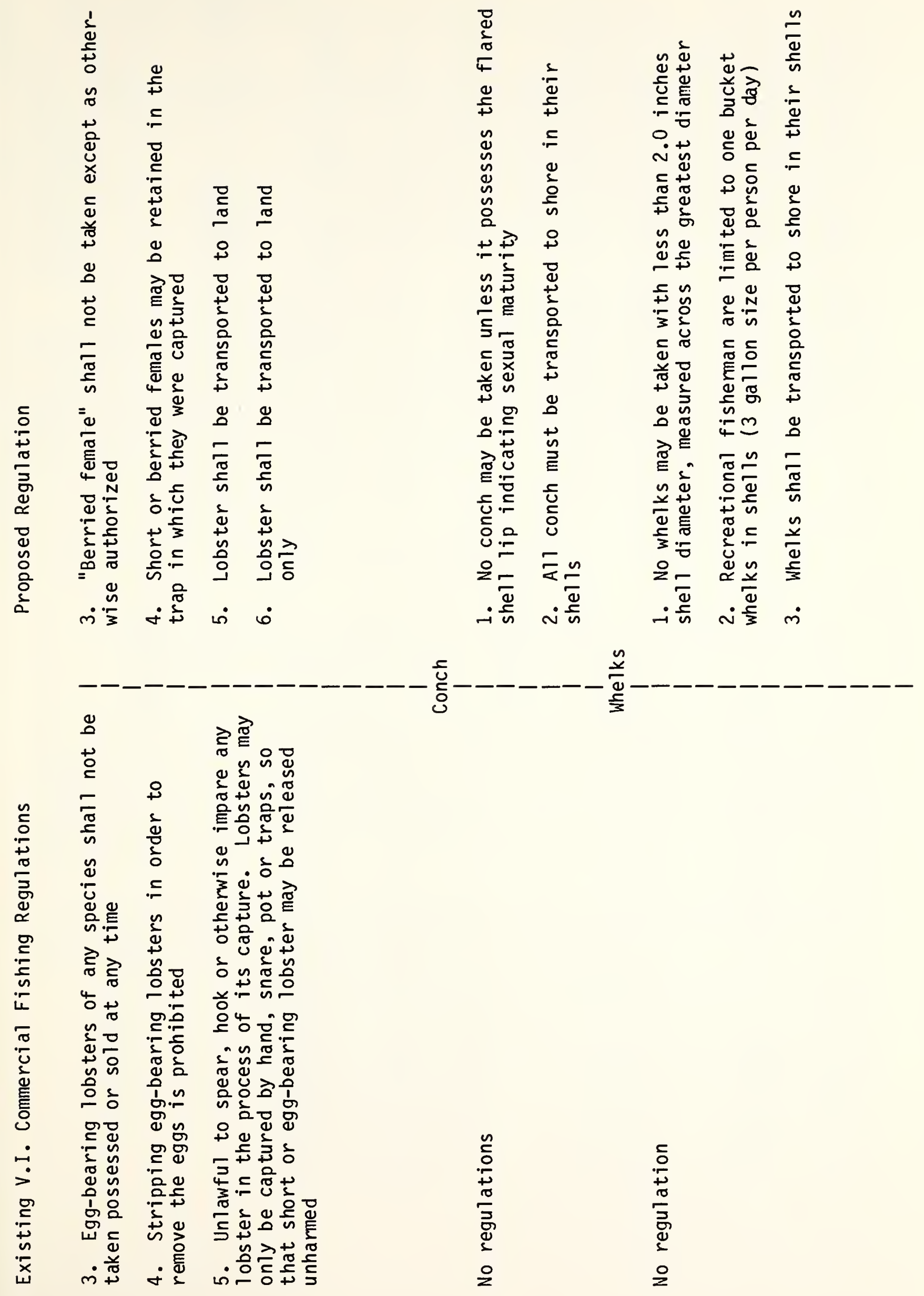




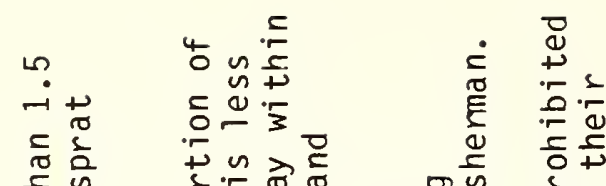

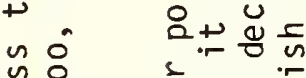

(1)을 $\frac{1}{2}+-4$

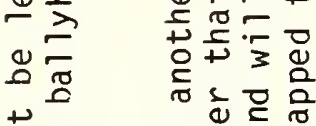

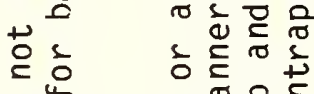

它品

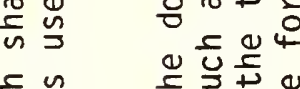

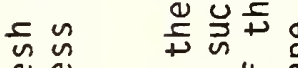

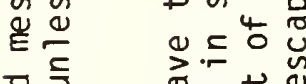

동

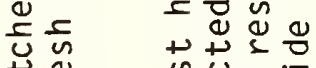

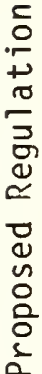

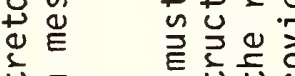

位

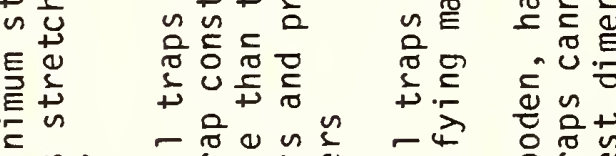

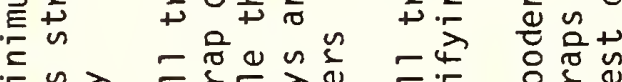

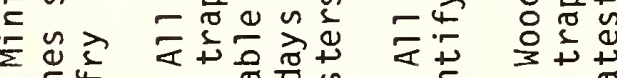

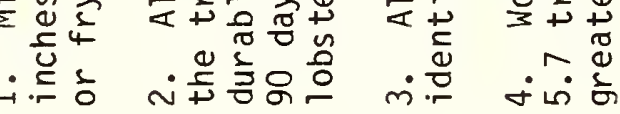

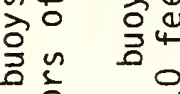

등 둥으

ऽ

离它立过

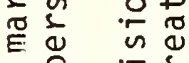

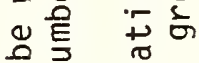

in n 0 口

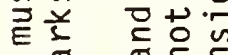

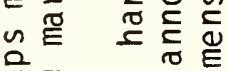

so

-

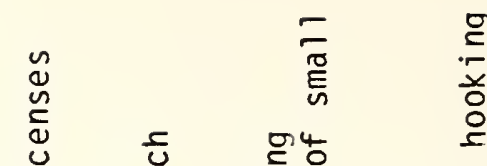

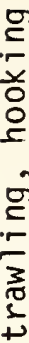

mir \& \&
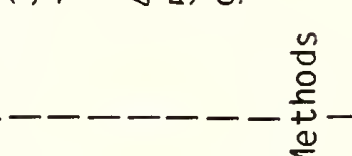

$\frac{\sqrt{n}}{\frac{5}{n}}$

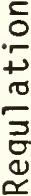

ฮั<smiles>C1CCCCC1</smiles>

$\frac{5}{0}$

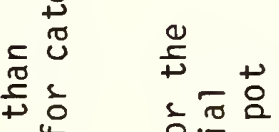

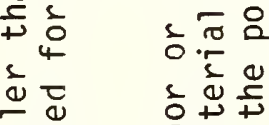

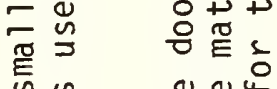

芯先至芒

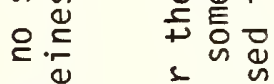

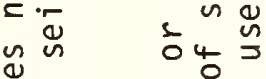

ज虽 证元

E्य

(1) ब a

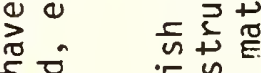

¿

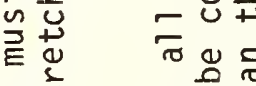

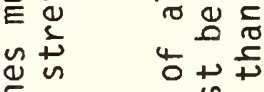

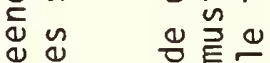

ज $\frac{1}{4}$

든

ज

g:

궁. 兄

I눈

.$\rightarrow$

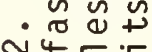

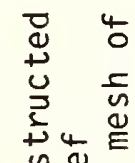

气

广ठ

\&도

它 尊

+ ᄃ

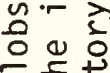

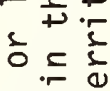

$+5+$

8.40

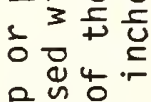

융

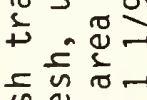

岳崖西

원원

$2 \cdot \frac{\pi}{3}$

3
$\dot{0}$
0

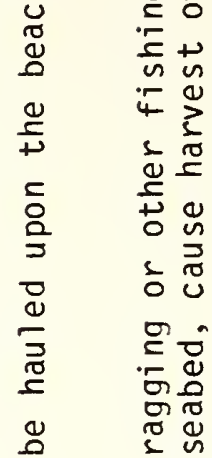

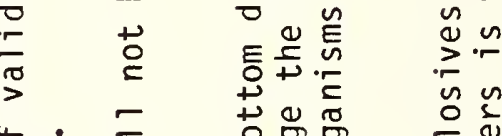

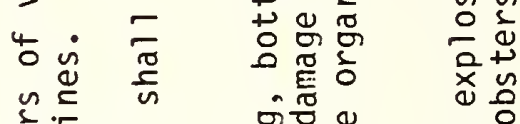

ㅎํ ¿

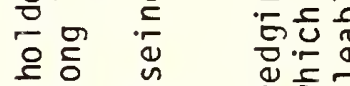

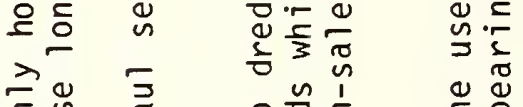

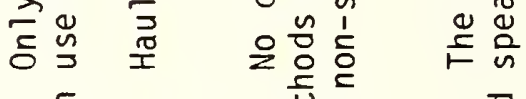

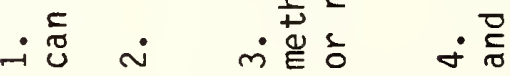

$\therefore$

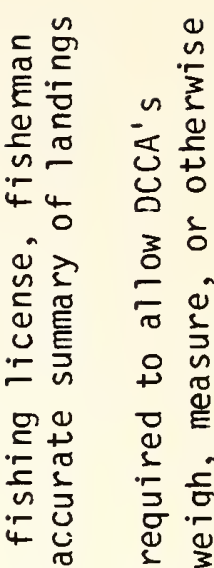

సٓ.

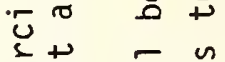

兽言

ه

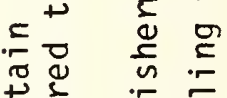

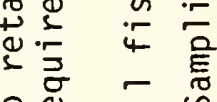

일 严

$-\frac{0}{\pi} \sim$ 完

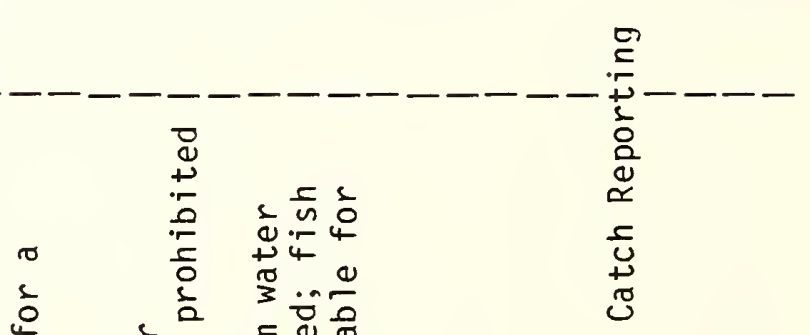




\section{Pollution Control}

1. Water Pollution Control Act (12 VIC $\$ 181$ et. seq.)

The Water Pollution Control Act (WPCA) is the territorial counterpart to the federal statute and is intended to conserve, protect, maintain and improve the quality of the waters of the Virgin Islands, including the territorial seas (12 VIC $\$ 181$ ). The DCCA is declared to be the Water Pollution Control Agency of the Virgin Islands and is made responsible for developing comprehensive programs for the prevention, control and abatement of all existing or potential pollution of the waters of the Virgin Islands, including participation in the National Pollution Discharge Elimination System (NPDES) (12 VIC $\$ 184)$. Under the WPCA, the waters of the proposed sanctuary are designated class "B".

The Act prohibits the discharge of any pollutant without a permit (12 VIC $\$ 185)$ and the DCCA is authorized to issue permits for pollutant disharges. Permits must insure that the Federal discharge standards promul gated pursuant to the Clean Water Act and any more stringent standards set by other territorial of Federal law are complied with (12 VIC \$185). In addition to the general requirement that a permit be obtained for the discharge of any pollutant, the following activities are explicitly subject to the permit requirement:

1) construction, installation, modification or operation of any di sposal system;

2) the increase in volume or strength of any pollutant in excess of that specified in an existing permit;

3) the construction, installation, operation or modification of any industrial, commercial or other establishment which would increase the discharge of pollutants or would otherwise alter the waters of the Virgin Islands. 12 VIC $\$ 185$.

Pursuant to its responsibilities under the Act, DCCA has instituted a Territorial Pollution Discharge Elimination System (TPDES). The TPDES regulations provide a comprehensive scheme of water pollution control through the issuance of permits by the Department. No person is permitted to discharge any pollutant wi thout a TPDES permit (12 VIR \& R \$184-11). However, permits issued pursuant to the Federal Refuse Act or the NPDES are deemed to be issued under the Act.

The regulations also adopt the water quality standards for the coastal waters of the Virgin Islands, which generally require the waters to be free of the following substances attributable to discharges:

a) materials which settle to form objectionable deposits;

b) floating debris, oil, scum, and other matter;

c) substances producing objectionable color, odor, taste or turbidity; 
d) materials, including radionucleotides, in concentrations or combinations which are toxic or produce undesirable physiological responses in humans, fish or other animal life, and plants;

e) substances and conditions which produce undesirable aquatic life. 12 VIC $\$ 186-1$.

In addition to general standards the regulations establish specific criteria to be used as the basis for setting effluent limitations and establishing conditions for individual permits.

The regulations create three classes of waters for Virgin Islands; A, B, and $C$. They require that in Class $A$ waters existing natural conditions not be changed. Class $B$ waters must be maintained so as to assure propagation of desirable species of marine life for primary contact recreation (boating, wading, etc.). Levels for the major water quality indicators are set for Class $B$ and Class $C$ areas, with the criteria somewhat more lenient for Class $C$ areas. All waters within the boundaries of the proposed St. Thomas Marine Sanctuary are Class B waters. (12 VIC \$186-11).

The WPCA empowers the DCCA to exempt certain discharges from the permit process. 12 VIC $\$ 185$. Pursuant to this authority the DCCA does not require a permit for the following:

a) any discharge of sewage from vessels, including effluents from marine engines, laundry, shower, and galley sink wastes, or any other discharge incidental to nomal vessel operation; provided, it is in compliance with applicable territorial or Federal 1 aw. (The exception does not apply to rubbish, trash, garbage, or other such materials discharged overboard;

b) dredged or fill materials discharged into navigable waters;

c) additions of pollutants into treatment works otherwise in compliance if proper notice is given;

d) discharges conforming to the National Contingency Plan published pursuant to the Federal Clean Water Act;

e) and water, gas, or other material injected into a well to facilitate production of oil or gas, if approved by the DCCA and if the DCCA has determined it will not result in degradation of ground or surface water. (12 VIR \& R \$184-12).

While, the focus of the WCPA is to protect, conserve, maintain and improve the quality of the waters of the Virgin Islands, the scope of the Act is limited to the discharges of pollutants, primarily wastewater from sewage treatment plants. The discharge of vessel wastes or dredged materials are exempt, presumably leaving regulation of these activities to the permit programs established under the VICZMA, and Federal statutes. 
2. The 0 il Spill Prevention and Pollution Control Act (12 VIC \$701 et seq.)

The 0il Spill Prevention and Pollution Control Act (OSPPCA) is designed to protect the waters and the shorelines of the Virgin Islands from the threat of contamination resulting from the spillage or discharge of oil or other pollutants (defined as oil of any kind and in any form, gasoline, pesticides, ammonia, chloring and other hazardous materials) during their transfer, storage and transport.

The OSPPCA also provides for cooperation with Federal oil spill response efforts. The pilot and the master of a vessel casuing a discharge must immediately report it to the U.S. Coast Guard, 12 VIC $\$ 708$, and the DCCA, in its planning and response efforts, is directed to act in accordance with the national contingency plan for removal of $0 i 1$ and other pollutants discharged into the navigable waters of the United States.

\section{Solid and Hazardous Waste Management Act (19 VIC \$1551 et seq).}

The Solid and Hazardous Waste Management Act (SHWMA) provides for the proper storage, transportation and disposal of wastes (19 VIC \$1551). While the Virgin Islands Department of Public Works has primary responsibility for administering the Act, the DCAA is responsbile for enforcing the provisions of the Act within territorial submerged lands and waters, issuing permits for disposal sites, and inspecting disposal sites (19 VIC \$1556). The Act prohibits the dumping of any wastes except in a place designated for that purpose, and the dumping of any material on an artificial reef without written permission from the DCCA (19 VIC \$1563).

D. Other

1. Executive Order No. 241-1980

On December 18, 1980 the Governor of the Virgin Islands issued Executive Order No. 241-1981 to establish the Division of Fish and Wildlife within the Department of Conservation and Cultural Affairs. The effective date of the Executive Order was January 1, 1981. The Executive Order establishes a Division Director, a Bureau of Wildlife Programs headed by a Chief, and a Fiscal Officer.

Among the functions and duties of the Division are those related to activities concerning administration of Federal programs including the National Marine Sanctuary Program. The Division also administers all Virgin Islands or Federal programs pertaining to the Virgin Islands fishermen that are not exclusively within the jurisdiction of the Virgin Islands' Department of Commerce under IIV.I.C. $\$ \$ 1401-1406$. The Division also serves as liason agency with the Carribbean Fisheries Management Council.

\section{FEDERAL AUTHORITIES}

The proposed sanctuary is entirely within the Virgin Islands territorial waters and, therefore, the territorial authorities provides the primary basis for resource management and protection. Federal regulatory authority is relevant with respect to the protection of endangered species and marine mammals, pollution control, and vessel safety and traffic. 


\section{A. Protection of Endangered Species and Marine Mammals}

\section{The Endangered Species Act of 1973 (ESA) (16 USC \$1531 et. seq.)}

The most significant protection provided by the ESA is the prohibition on taking. The term "take" is defined broadly to mean "harass, harm, pursue, hunt, shoot, wound, kill, trap, capture, or collect or to attempt to engage in such conduct" (16 USC $\$ 1532$ (14)). The U.S. Fish and Wildlife Service regulations interpret the term "harm" to include significant environmental modification or degradation and acts which annoy listed species to such an extent as to significantly disrupt essential behavior patterns (50 CFR 17.3).

The ESA also provides for the indirect protection of endangered species and certain habitat. This is accomplished by means of a consultation process design to insure that projects authorized, funded, or carried out by the Federal agencies is not jeopardizing the continued existence of endangered or threatened species or "result in the destruction or modification of habitat of such species which is determined by the Secretary (of the Interior) to be critical" (16 USC \$1536). Critical habitats area for endangered species are designated by the FWS and NMFS depending on the species. The 1978 amendments to the ESA established a Cabinet level committee authorized to exempt Federal agencies from compliance with their responsibility in regard to critical habitats upon a finding that these are not reasonable alternatives to the action, and that its benefits outweigh those of conserving species or their critical habitat. State and private projects are not covered by these provisions.

\section{Marine Mammal Protection Act of 1972 (MMPA) (16 USC $\$ \$ 1361$ et seq.)}

The MMPA applies to U.S. citizens and foreign nationals subject to U. S. jurisdiction, and is designed to protect all species of marine mammals. Provisions of the MMPA are implemented by the Department of Commerce, National Marine Fisheries Service (NMFS), which is responsible for whales, porpoises, and pinnipeds other than the wal rus, and the Department of the Interior, U. S. Fish and Wildlife Service (FWS), which is responsible for all other marine mammals. The Marine Mammal Commission advises these implementing agencies and sponsors relevant scientific research. The primary management features of the Act include: (1) a moratorium on the "taking" of marine mammals, (2) the development of a management approach designed to achieve an "optimum sustainable population" (OSP) for all species or population stocks of marine mammals, and (3) additional protection of populations determined to be "depleted."

The term "take" is defined broadly to include "harass, hunt, capture, or kill any marine mammal" (15 USC \$1362(13)), emphasis added). The term "harass" has been interpreted to encompass acts unintentionally adversely affecting marine mammals. The MMPA allows certain exceptions to the moratorium.

The Secretaries of the Interior and Commerce can also waive the moratorium on taking of particular species or populations of marine mammals, provided that the species or population is at or above its determined OSP. No such waiver, however, has been granted for the study area. 
Secondly, the MMPA directs officials to seek "an optimum sustainable population (of marine mammals)" (16 USC $\$ 1361(6))$. That OSP is defined to mean "the number of animals which will result in the maximum productivity of the population or species keeping in mind the carrying capacity of the habitat and health of the ecosystem of which they form a constituent element" (16 USC $\$ 1352(9)$ ).

Marine mammal species whose population is determined to be depleted receive additional protection (16 ISSC \$1362). Except for scientific research purposes, no permit may be issued for the taking of any marine mammal determined to be depleted.

\section{B. Management of Commercial and Recreational Fisheries}

. The Fishery Conservation and Management Act of 1976 (FCMA), (16 USC $\$ 1801$, et seq.)

The (FCMA) provides for the conservation and management of all fishery resources in the zone between 3 and $200 \mathrm{nmi}(5.6-370 \mathrm{~km})$ offshore. The authority of the Caribbean Fishery Management Council (CFMC) of which the Virgin Islands is a member is limited within the territorial sea and implementation of the CFMC plans are contingent upon coordination with the Virgin Islands government. However, the Virgin Island has an informal commi tment to implement the FMPs and the Fishery Advisory Committee is making recommendations for changes in the Virgin Island Commercial Fishery Act to bring VI fishing regulations into compliance (see Section 1., Territorial Authorities). The CFMC is currently developing several FMP's.

\section{Control of Pollution}

1. The Clean Water Act, 33 USC $\$ 1251$ et seg. (CWA)

It is the goal of the CWA to restore and maintain the chemical, physical, and biological integrity of the Nation's waters. To varying degrees, waters in the territorial sea, contiguous zone, and the ocean beyond are subject to the requirements of the CWA, as outlined below.

Permits from the Army Corps of Engineers (COE), which are based on Environmental Protection Agency (EPA) guidelines, are required prior to dredging or the discharging dredged materials within $3 \mathrm{nmi}(5.6 \mathrm{~km})$ offshore. The Virgin Islands and the Corps have a joint application where both a Corps and Territoral permit is required for dredging.

The National Pollutant Discharge Elimination System (NPDES), administered by EPA requires a permit for the discharge of any pollutant from a point source into the navigable waters of the United States The issuance of a permit is based primarily on effluent guidelines but permits can be issued for special circumstances on a case by case basis, EPA has delegated NPDES permitting authority to the Virgin Island Department of Conservation and Cultural Affairs (See Status Quo, Territorial Authority). 
The CWA requires non-commercial craft to comply with marine sanitation regulations issued by EPA and enforced by the United States Coast Guard (USCG) (33 USC \$1322). These regulations require that as of January 31,1980 , a1 1 vessels operating within the territorial sea must have Coast Guard certified sanitation devises or hol ding tanks (FR Volume 41 , No. $201 / 29 / 76$ ). The regulations prohibit the discharge of untreated wastes within the 3 mile limit.

The National Contingency Plan establishes the organizational framework whereby oil spills are to be cleaned up. To carry out the national plan, regional contingency plans (RCP) have been established; the USCG has issued such an RCP for Federal Region which includes the study area. Under the RCP, USCG personnel investigate all reported offshore spills, notify the party

responsible (if known) of their obligation to clean up the spill, and supervise the cleanup operation. The USCG retains final authority over the procedures and equipment used in the cleanup. If the party responsible for the spill does not promptly begin cleanup operations, the USCG can hire private organizations and seek to recover costs from the party responsible.

\section{Marine Protection, Research, and Sanctuaries Act (33 USC 1401-1444)}

Title I of the Marine Protection, Research, and Sanctuaries Act of 1972, (33 USC $\$ 1401$ et seq.). (MPRSA), al so known as the Ocean Dumping Act, regulates the dumping of materials into the territorial sea, the contiguous zone, and the ocean beyond. EPA regulates through the issuance of permits, the dumping of all materials except dredged materials over which COE exercises authority. At the present time, there are no pre-selected dump sites in or adjacent to the proposed sanctuary.

\section{Regulation of Navigation and Vessel Safety \\ 1. The River and Harbors Act (33 USG 401 et. seq.)}

Section 10 (33 USC 403) prohibits the unathorized obstruction of navigable waters of the United States. The construction of any structure in the territorial sea or on the outer continental shelf is prohibited without a permit from the Army Corps of Engineers.

Section 13 ( 33 USC <407) prohibits the discharge of refuse and other substances into navigable waters, but has been largely superseded by CWA. In effect such discharges are regulated under this section only insofar as they affect navigation or anchoring.

\section{E. Historical and Cultural Resources}

1. The National Historic Preservation Act (16 USC $\$ 470$ et. seq.)

The National Historic Preservation Act authorizes the Secretary of the Interior to maintain a national register of "districts, sites, buildings, structures, and objects significant in American history, architecture, archaelogy, and culture." Sites have been listed on the National Register which include or are composed entirely of ocean waters and submerged lands within state waters or on the Outer Continental Shelf (Lebovich, 1979, personal communication). No sites in the waters of the proposed sanctuary are listed 
on the National Register at the present time. However, the lighthouse on Buck Island was listed in the National Register in 1977.

Any Federal agency conducting, licensing, or assisting an undertaking which may affect a site listed on the National Register must provide the Advisory Council on Historic Preservation a reasonable opportunity to comment on the action (16 USC $\$ 470$ ). The criterion applied by the Council is used to determine whether the undertaking will change the quality of the site's historic architectural, archaeological or cultural character (36 CFR $\$ 800$ ). 

ANIMAL AND PLANT SPECIES LIST OF THE OF THE PROPOSED MARINE SANCTUARY MARINE-FLORA

$\begin{array}{ll}\text { Habitat Key: } & R-\text { Reef } \\ & \text { AP - Algal Plain } \\ & T \text { - Turtle Grass }\end{array}$

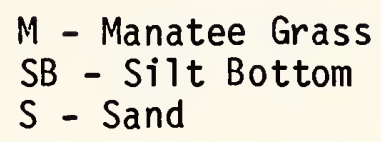

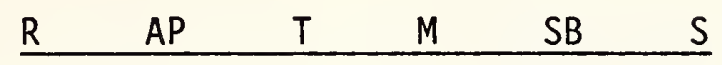

PH. SPERMATOPHYTA

Thal assia testudinum Halophila baillonis Syringodium filiforme Diplanthera wrightii

$x$
$x \quad x$
$x \quad x$
$x$

PH. CHLOROPHYTA

Avrainvillea nigricans

Caulerpa sertularioides

C. macrophysa

C. mexicana

C. $\frac{\text { cupressoides }}{\text { racemosa }}$

C. racemosa

Anadyoneme stellata

Halimeda opuntia

H. tuna

H. $\frac{\text { monile }}{\text { scabra }}$

H. $\overline{\text { scabra }}$

H. discoidea

$\bar{H}$. simulans

H. incrassata

Neomeris annu 7 ata

Penicillus capitatus

P. lamourouxi i

P. $\frac{\text { pyriformis }}{\text { pyrats }}$

Udotea flabe11um

U. verticillosa

U. cyarthiformes

U. conglutinata

U. spinulosa

Rhipelia tomentosum

Chaetomorpha crassa

C. linum

Dictyosphaeria cavernosa

Valonia ventricosa

Valoniopsis sp.

$\begin{array}{lllll}x & x & x & x & x \\ x & x & x & x & x\end{array}$

Ernodesmis verticillata 
MARINE FLORA

Dichtyosphaeria vanbosseae

Cladophora fuliginosa

$A P$

T

M

SB

S

Cladophoropsis membrancea

$\begin{array}{ll}x & x \\ x & x \\ x & x\end{array}$

PH. PHAEOPHYTA

Dictyota linearis

D. dichotoma

D. bartayressio

D. divaricata

D. indica

Lobophora variegata

Sargassum fillipendula

Pandina vickersiae

PH. RHODOPHYTA

Byrothmanion triquetrum

Calaxaura cyl indrica

Chrysymenia enteromorpha

Spyridia filamentosa

Gracilaria sp.

Hildenbrandia sp.

Laurencia sp.

$\begin{array}{lll}x & x & x \\ x & \end{array}$

Polysiphonia sp.

Lithothamnion sp.

Chondria polyrhiza

Gelidium sp.

Asparigopsis sp.

Digenia simplex

Ralfsia sp.

Laurencia intricata

Jania sp.

Wrangelia verticillata

Martensia pavonia

Amphiroa rigida

A. fragilissima

Corallina cubensis

Junia pumila

Hypnea musciformis

Botryoc Tadia pyriformis

Coelothrix irregularis

Champia parvula

Crouania attenuata

Wrangelia argus

Callithamnion halliae

Acanthophora spicifera

Geraminum fastigation

$x \quad x$

$x$

$x \quad x \quad x$

$\begin{array}{lll}X & X & X \\ & X & X \\ X & X & X \\ X & X & \\ X & X & X \\ X & & \end{array}$

$x$

$x$

$x \quad x$

$x$

$x$

$x$
$x$
$x \quad x$
$x$

$x \quad x$

$x$

$x$

$x$

$x$

$x$

$x$

$x$

$x$
$x \quad x$

$\begin{array}{ll}x & x \\ x & x\end{array}$

$x \quad x$

$x \quad x$

$x \quad x$

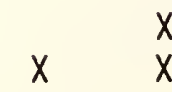

$x$

$x \quad x$




$\begin{array}{llllll}R & A P & T & M & S B & S\end{array}$

PH. MOLLUSCA

Astraea longispina Cerithium literatum

Spondylus americanus

Strombus pugilis

S. gigas

S. costatus

Cymatium vespaceum

Colubaria testacea

Turitella exoleta

Chione sp.

Polinices sp.

Arca imbricata

Xenophora cochyliophora

Pinna carnea

Cymatium martinianum

C. poulseni

Distorsio clathrat

Murex chrysostoma

M. pomum

$\bar{M}$. brevifrons

Muricidea hexagona

Latiaxis deburghiae

Coralliophila abrreviata

Conus pygmaeus

Fasciolaria tulipa

Tellidora cristata

Trachycardium sp.

INTERTIDAL MOLLUSCS

Nodolittorina tuberculata

Littorina angulifera

Tectarium muricatus

Littorina ziczac

Chiton tuberculatus

Acanthopleura granulata

Chiton marmoratus

Fissurella nodosa

Acmaea anti 11 arum

Cittarium pica

Astrea tuber

Astrea tecta

Neritina pumtulata

Littorina meleagris

Nerita peloronta

Planaxis nucleus

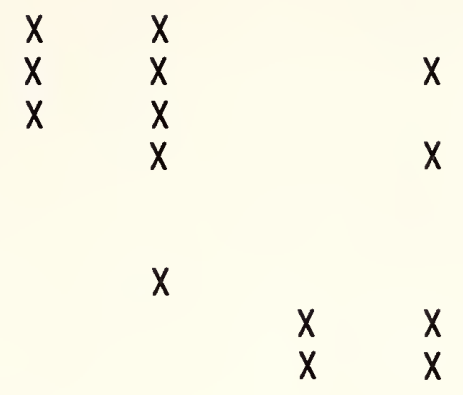

$x$

$x$

$x$

$x$

$x$
$X$
$X$
$x$

$x$ 
Thais deltoidea

Latirus brevicaudatus

Nerita versicolor

PH. PORIFERA

Callispongia vaginallis

Chondril1a nucula

Damyriela sp.

Iotrocota $\mathrm{sp}$.

Tedamia ignis

R

$A P$

$M$ $S$

Haliclono rubens

Haliclona sp.

Microciona sp.

Euryspongia roseae

UTosa hispida

Iricina strobilina

Neotibula sp.

Iotrochota sp.

Aplysilla sp.

Verongia sp.

$\begin{array}{ll}x & x \\ x & x \\ & x \\ x & x\end{array}$

PH. ECHINPDERMATA

Oreaster reticulata

Tripneustes esculentus

Echinometra viridis

E. lucunter

Diadema antillarum

Holothuria mexicana

Ophiocoma flaccida

$x \quad x \quad x$

$\begin{array}{ll}x & x \\ x & x\end{array}$

$x \quad x \quad x$

$x \quad x$

$x$

PH. COELENTERATA

HYDROZOA

Millipora alciocornis $\quad X \quad X$

M. complanata

M. squarrosa

$x \quad x$

ANTHOZOA

Agaricia agaridites

A. fragilis

Astrangia solitaria

Manicina aereolata

Isophyl1ia sinuosa

Meandrina meandrites

Montastrea annularis

Mussa angulosa

Porites asteroides

P. porites

$x \quad x$

$\underline{\text { Siderastrea siderea }}$

$\begin{array}{lll}X & x \\ X & x & \\ X & X & \\ X & & \\ X & & \\ X & X & \\ X & X \\ X & & \\ X & X \\ X & \end{array}$




$\begin{array}{llllll}R & A P & T & M & S B & S\end{array}$

S. radians

Favia fragum

Oculina diffusa

Eusmilia fastigiata

Cladocora arbuscula

Dichocenia stokesii

Diploria cl ivosa

Solenastrea hyades

Dendrogyra sp.

Cerianthus sp.

Aptasia annulata

Diploria labyrinthiformis

Montastrea cavernosa

Dichocoenia stokesii

Stephanocoenia michel ini

Acropora cervicornis

Acropora prolifera

Madracis decactis

$x$

$x$
$x \quad x$

$x$

$x$

$x$

$x$

$x$

$x$

$x$

$x$

$x$

$x$

$x$

$x$

ALCYONARIA

Pseudoplexaura sp.

Pseudopterogorgia americanum

Unidentified gorgonian

Plexaura crassa

Plexaurella sp.

Eunicea crassa

E. Taxispica

$\begin{array}{ll}x & x\end{array}$

$x \quad x$

$x \quad x$

$\begin{array}{ll}x & \\ X & x\end{array}$

$x \quad x$

SCYPHOZOA

Cassiopea frondosa

PH. ARTHROPOSA

Clibanarius tricolor

Paguristes puncticeps

Petrochirus bahamensis

Calappa sp.

Calcinus tibicen

$x \quad x$

PH. ANNELIDA

Sabel lastarte magnifica

Hermodice sp.

Sabella sp.

Spirobranchus giganteus

Pomatostegus stellatus

Eupolymania nebulosa

$x$

$x$

$x \quad x \quad x$

$x$

$x$

$x$ 
Class Chondrichythyes

Order Squaliformes

Family Orectolobidae - Carpet sharks Ginglymostoma cirratum - Nurse shark

Family Carcharhinidae - Requiem sharks

Carcharhinus limbatus - Blackt ip shark

C. springeri - Reef shark

Galeocerdo cuvier - Tiger shark

Negraprion brevirostris - Lemon shark

Prionace glauca - Blue shark

Rhizoprionodon porosus - Sharpnose shark

Family Sphyrnidae - Hammerhead sharks

Order Raji formes

Sphyrna mokarran - Great hammerhead

Family Dasyatidae - Stingrays

Dasyatis americana - Southern stingray

Urolophus jamaicensis - Yellow stingray

Class Osteichthyes

Family Myliobat idae - Eagle rays

Order Elopiformes

Family Elopidae - Tarpons

Elops saurus - Ladyfish

Megalops at Tanticus - Tarpon

Order Anguilliformes

Family Muraenidae - Morays

Echidna catenata - Chain moray

Enchelycore nigricans - Viper moray

Gymnothorax funebris - Green moray

G. moringa - Spotted moray

$\underline{G}$. Vicinus - Purplemouth moray

Muraena miliaris - Goldentail moray

Order Clupeiformes

Family Clupeidae - Herrings

Harengula clupeola - False pilchard

H. humeralis - Redear sardine

Jenkinsia lamprotaenia - Dwarf herring

Famil y Engrauli $i \overline{d a e ~-~ A n c h o v i e s ~}$

Anchoa lyolepis - Dusky anchovy

Order Myctophiformes

Family Synodontidae - Lizardfishes

Synodus foetens - Inshore lizardfish

S. intermedius - Sand diver

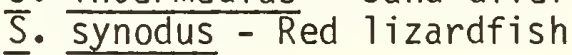

Order Lophï formes

Family Antennariidae - Frogfishes

Antennarius multiocellatus - Longlure frogfish

Family Orgcocephalidae - Batfishes

Order Atheriniformes

Ococephalus nasutus - Shortnose batfish

Family Exocoetidae - Flyingfishes and Halfbeaks 
Hemiramphus balao - Balao

H. brasiliensis - Ballyhoo

Family Belonidae - Needlefishes

Platybelone argalus - Keeltail needlefish

Strongylura notata - Redfin needlefish

S. timucu - Timucu

Tylosurus crocodilus - Houndfish

Family Atherinidae - Silversides

Order Bercyciformes

Allanetta harringtonensis - Reef silverside

Family Holocentridae - Squirrelfishes

Holocentrus ascensionis - Squirrelfish

H. coruscus - Reef squirrelfish

$\bar{H}$. marianus - Longjaw squirrelfish

$\bar{H}$. rufus - Longspine squirrelfish

H. vexillarius - Dusky squirrelfish

Myripristis jacobus - Blackbar soldierfish

Plectrypops retrospinis - Cardinal soldierfish

Order Gasteros tei formes

Family Aul os tomidae - Trumpetfishes

Aulustomus maculatus - Trumpetfish

Family Sygnathidae - Pipefishes and seahorses

Order Perci formes

Hippocampus reidi - Longsnout seahorse

Family Centropomidae - Snooks

Centropomus undecimalis - Snook

Family Serranidae - Sea Basses

Alphestes afer - Mutton hamlet

Cephalopholis fulva - Coney

Dermatolepis inermis - Marbled grouper

Ephinephelus adscensionis - Rock hind

E. guttatus - Red hind

E. itajara - Jewfish

E. striatus - Nassau grouper

Hypoplectrus indigo - Indigo hamlet

H. nigricans - Black hamlet

$\bar{H}$. puella - Barred hamlet

Liopropoma rubre - Peppermint bass

Mycteroperca bonaci - Black grouper

M. phenax - scamp

$\bar{M}$. tigris - Tiger grouper

$\bar{M}$. venenosa - Yellowfin grouper

Paranthias furcifer - Creole fish

Petrometopon cruentatus - Graysby

Serranus tabacarius - Tobaccofish

S. tigrinus - Harlequin bass

$\bar{s}$. tortugarum - Chalk bass

Family Grammidae - Fairy basslets

Gramma loreto - Fairy basslet 
Haemulon chrysargyreum - Smallmouth grunt

H. flavolineatum - French grunt

$\bar{H}$. macrostomum - Spanish grunt

H. melanurum - Cottonwick

$\bar{H}$. parra - Sailors choice

H. plumieri - White grunt

H. sciurus - Bluestriped grunt

‥ . striatum - Striped grunt

Family Sparidae - Porgies

Archosargus rhomboidalis - Sea bream

Calamus bajonado - Jolthead porgy

C. calamus - Saucereye porgy

C. penna - Sheepshead porgy

C. pennatula - Pluma

Diplodus caudimacula - Roundspot porgy

Pagrus sedecim - Red porgy

Family Sciaenidae - Drums

Equetus lanceolatus - Jackknife-fish

E. punctatus - Spotted drum

E. umbrosus - Cubbyu

Family Mullidae - Goatfishes

Mulloidichthys martinicus - Yellow goatfish

Pseudupeneus maculatus - Spotted goatfish

Fami 1y Pempheridae - Sweepers

Pempheris poeyi - Shortfin sweeper

P. schomburgki - Glassy sweeper

Family Kyphosidae - Sea chubs

Kyphosus sectatrix - Bermuda chub

Family Ephippidae - Spadefishes

Chaetodipterus faber - Atlantic spadefish

Family Chaetodontidae - Butterflyfishes

Chaetodon capistratus - Foureye butterflyfish

C. ocellatus - Spotfish butterflyfish

C. sedentarius - Reef butterflyfish

C. striatus - Banded butterflyfish

Holacanthus bermudensis - Blue angelfish

H. ciliaris - Queen angelfish

$\bar{H}$. $\overline{\text { tricolor }}$ - Rock beauty

Pomacanthus arcuatus - Gray angelfish

P. paru - French angelfish

Prognathodes aculeatus - Longsnout butterflyfish

Fami 1y Pomacentri dae - Damselfishes

Abudefduf saxatilis - Sergeant major

A. taurus - Night sergeant

Chromis cyaneas - Blue chromis

C. multilineatas - Brown chromis

Microspathodon chrysurus - Yellowtail demselfish

Pomacentrus fuscus - Dusky damselfish

Pomacentrus leucostictus - Beaugregory

P. partitus - Bicolor damselfish

$\bar{P}$. planifrons - Threespot damselfish

$\bar{p}$. variabilis - Cocoa damselfish

Family Cirrhitidae - Hawkfishes

Amblycirrhitus pinos - Redspotted hawkfish 
Family Labridae - Wrasses

Bodianus pulchellus - Spotfin hogfish

B. rufus - Spanish hogfish

Clepticus parrae - Creole wrasse

Doratonotus megalepis - Dwarf wrasse

Halichoeres bivittatus - Slippery dick

H. garnoti - Yellowhead wrasse

$\bar{H}$. maculipinna -. Clown wrasse

$\bar{H}$. pictus - Rainbow wrasse

$\bar{H}$. poeyi - Blackear wrasse

$\bar{H}$. radiatus - Puddingwi fe

Hemipteronotus martinicensis - Rosy razorfish

H. novacula - Pearly razorfish

$\bar{H}$. splendens - Green razorfish

Lachnolaimus maximus - Hogfish

Thalassoma bifasciatum - Bluehead

Family Scaridae - Parrotfishes

Cryptotomus roseus - Bluelip parrotfish

Scarus coelestinus - Midnight parrotfish

Scarus coeruleus - Blue parrotfish

S. croicensis - Striped parrotfish

$\bar{S}$. guacamaia - Rainbow parrotfish

$\bar{S}$. taeniopterus - Princess parrotfish

$\bar{S}$. vetula - Queeen parrotfish

Sparisoma aurofrenatum - Redband parrotfish

S. chrysopterum - Redtail parrotfish

$\bar{S}$. radians - Bucktooth parrotfish

$\bar{S}$. rubripinne - Redfish parrotfish

S. viride - Spotlight parrotfish

Family Mugilidae - mullets

Mugil curema - White mullet

Family Sphyraenidae - Barracudas

Sphyraena barracuda - Great barracuda

S. picudilia - Southern sennet

Family Polynemidae - Threadfins

Polydactylus oligodon - Littlescale threadfin

P. virginicus - Barbu

Fami $1 \bar{y}$ opistognathidae - Jawfishes

Opistognathus aurifrons - Yellowhead jawfish

0. cuvieri - Phantom jawfish

0. macrognathus - Spotfin jawfish

0. maxillosus - Mottled jawfish

0. whitehursti - Dusky jawfish

Family ciinidae - Clinids

Chaenopsis limbaughi - Yellowface pikeblenny

Emblemaria pandionsis - Sailfin blenny

Malacoctenus triangulatus - Saddled blenny

Family Blennidae - Combtooth blennies

Blennius cristatus - Molly miller

Ophioblennius atlanticus - Redlip blenny

Family Callionymidae - Dragonets

Callionymus bairdi - Lancer dragonet 
Family Acanthuridae - Surgeonfishes

Acanthurus bahianus - Ocean surgeon

A. chirurgus - Doctorfish

$\bar{A}$. coeruleus - Blue tang

Family Scombridae - Mackerels and Tunas

Acanthocybium solanderi - Wahoo

Euthynnus alletteratus - Little tunny

E. pelamis - Skipjack tuna

Scomberomorus cavalla - King mackerel

S. maculatus - Spanish mackerel

S. regalis - Cero

Thunnus alalunga - Albacore

T. albacares - Yellowfin tuna

$\bar{T}$. atlanticus - Blackfin tuna

Family Scorpaenidae - Scorpionfishes

Scorpaena plumieri - Spotted scopionfish

S. grandicornis - Grass scorpionfish

$\bar{S}$. brasiliensis - Barbfish

Family Dactylopteridae - Flying gurnards

Order Pleuronecti formes

Dactylopterus volitans - Fling gurnard

Family Bothidae - Left-eye flounders

Bothus lunatus - Peacock flounder

B. ocel latus - Eyed flounder

Family Cynoglossidae - Tonguefishes

Symphurus arawak - Caribbean tonguefish

Order Tetraodontiformes

Family Balistidae - Triggerfishes \& Filefishes

Alutera schoepfii - Orange filefish

A. scripta - Scrawled filefish

Balistes vetula - Queen triggerfish

Cantherhines macrocerus - Whitespotted filefish

C. pullus - orangespotted filefish

Canthidermis sufflamen - Ocean triggerfish

Melichthys niger - Black durgon

Monacanthus ciliatus - Fringed filefish

M. tuckeri - Slender filefish

Xanthichthys ringens - Sargassum triggerfish

Family 0straciontidae - Boxfishes

Lactophrys bicaudalis - Spotted trunkfish

L. polygonia - Honeycomb cowfish

[. quadricornis - Scrawled cowfish

[. trigonus - Trunkfish

[. triqueter - Smooth trunkfish

Family Tetraodontidae - Puffers

Canthigaster rostrata - Sharpnose puffer

Sphaeroides greeleyi - Caribbean puffer

S. spengleri - Bandtail puffer

Fami iy Diodontidae - Porcupinefishes

Chilomcterus antennatus - Bridled burrfish

Diodon holocanthus - Balloonfish

D. hystrix - Porcupinefish 
Family Grammistidae - Soapfishes

Rypticus saponaceus - Greater soapfish

Family Pariacanthidae - Bigeyes

Priacanthus arenatus - Bigeye

P. cruentatus - Glasseye snapper

Fami $\bar{y}$ Apogonidae - Cardinalifishes

Apogon binotatus - Barred cardinalfish

A. maculatus - Flamefish

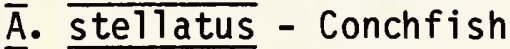

Family Branchiostegidae - Tilefishes

Malacanthus plumieri - Sand tilefish

Fami ly Rachycentridae - Cobias

Rachycentron canadum - Cobia

Fami 1y Echeneidae - Remoras

Echeneis naucrates - Shark sucker

Remora remora - Remora

Family Carangidae - Jacks and pompanos

Alectis crinitus - African pompano

Caranx bartholomaei - Yel low jack

C. crysos - Blue runner

C. $\overline{\text { hippos }}$ - Creval le jack

C. Tugubris - Black jack

C. $\frac{\text { ruber - Bar jack }}{\text { rupterus }}$

Decapterus macarellus - Mackerel scad

D. punctatus - Round scad

Elagatis bipinnulata - Rainbow runner

O1igoplites saurus - Leatherjacket

Selar crumenophthimus - Bigeye scad

Seriola dumerili - Greater amberjack

S. rivoliana - Almaco jack

Trachinotus falcatus - Permit

T. goodei - Palometa

Fami $\bar{y}$ Coryphaenidae - Dolphins

Coryphaena hippurus - Dolphins

Family Lutjanidae - Snappers

Lutjanus analis - Mutton snapper

L. apodus - Schoolmaster

L. campechanus - Red snapper

L. cyanopterus - Cubera snapper

L. griseus - Gray snapper

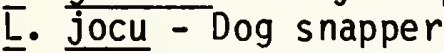

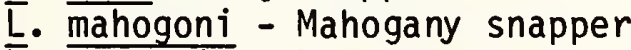

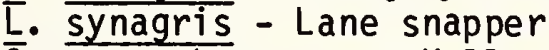

Ocyurus chrysurus - Yellowtail snapper

Fami 1 y Gereidae - Mojarras

Gerres cinereus - Yellowfin mojarra

Family Pomadasyidae - grunts

Anisotremus surinamensis - Black Margate

A. virginicus - Porkfish

Haemulon album - Margate

H. aurolineatum - Tomtate

$\bar{H}$. bonariense - Black grunt

‥ Carbonarium - Caesar grunt 
SCIENTIFIC NAME

Eretmochelys imbricata

Dermochelys coriacea

Lepidochlys kempii

Megaptera novaeangcliae

Physeter catodon

Balaenoptera spp.

Chelonia mydas

Caretta caretta
COMMON NAME

Hawksbill Turtle Leatherback Turtle

Atlantic Ridley Turtle

Humpback Whale

Sperm Whale

Rorqual Whale

Green Sea Turtle

Loggerhead Sea Turtle

TERRESTRIAL FLORA

SCIENTIFIC NAME

CACTACEA

Cephalocereus royenii

Opuntia rubescens

Cactus Inortus

APOCYNACEAE

Plumeria alba

VERBENACEAE

Lantana Involucrata

Avicennia nitida

CONVOLVULACEAE

Ipomoea Pes - Caprae

RUB IACEAE

Randia aculleata

Genipa americana

MAL VACEAE

Thespesia populnea

Hibiscus tiliaceus

BOT IDACEAE

Batis Maritima

$$
\begin{aligned}
& \text { G - Groundcover } \\
& S \text { - Shrub } \\
& T \text { - Tree }
\end{aligned}
$$

COMMON NAMES

$\begin{array}{ll}\text { Pipe Cactus } & \text { S } \\ \text { Prickey Pear Cactus } & \text { S } \\ \text { Barrel Cactus } & \text { S }\end{array}$
White Frangi Pani T/S

Sage

Black Mangrove

$\mathrm{S}$

Baybean, Goatsfoot G

Box-Briar, Inkberry

Genip

S

Haiti - Haiti

$T / S$

Sea Hibiscus

$T / S$

$S$
$S$
$T / S$

G

Sal twort

G 
BORAGINACEAE

Bourreria succulenta

Pigeon-Berry

RUTACEAE

Triphasia trifolia

Lime Berry

AIZOACEAE

Sesuvium portulacastrum

Sea Spinach

ANACARD IACEAE

Comocladia dodonaea

Christmas Bush

BROMEL IACEAE

Bromelia pinguin

Ground Pinquin

G

Tillandsia sp

Bromeliad

Epiphyte

LILIACEAE

Yucca aloifolia

Spanish bayonet

$T / \mathrm{s}$

MAMMALS

Stenoderma rufum

Molossus molossus

Noctilio Teporinus

Artibeus jamaicensis

Rattus rattus

R. norvegicus

Mus musculus

Herpestes auropunctatus

0docoileus virginianus

Red Fruit Bat

Vel vety Free-tailed Bat

Fisherman Bat

Fruit Bat

Roof Rat

Norway Rat

House Mouse

Smal1 Indian Mongoose

White-tailed Deer

\section{REPTILES}

Geochelone carbonaria

Ameiva exsui

Anolis cristatellus

A. pulchellus

A. stratulus

Hemidactylis mabovia

Iguana iguana

Mabuya mabouia

Sphaerodactylis macrolepis

Amphisbaena fenestrata

Alsophis portoricensis

Arrhyton exiguum

Epicrates monensis

Typhlops richardi

Red-footed Tortoise

Common Ground Lizard

Man Lizard

Sharp-mouthed Lizard

Salmon Lizard

Southern Woodslave

Iguana

Slippery back Skink

Common Dwarf Gecko

Virgin Islands Blind Snake

Ground Snake

Garden Snake

Mona Tree Boa

Common Worm Snake 
Bufo marinus

Eleutherodactylus antillensis

E. cochranae

E. coqui

$\bar{E}$. Tentus

Leptodactylus albilabris Osteopilus septentrionalis

AVIFAUNA

Podilymbus podiceps

Podiceps dominicus

Ardea herodias

Butorides virescens

Casmerodias alba

Egretta thula

Hydranassa tricolor

Nycticrax nycticoras

Nyctannassa violacea

Anas acuta

A. bahamensis

$\bar{A}$. crecca

$\bar{A}$. discors

$\bar{A}$. (mareca) americana

$\bar{A} y$ thya affinis

Oxyura jamaicensis

Phaethon actherus

P. lepturus

Pelecanus occidental is

Sula dactylatra

S. sula

$\bar{S}$. $\overline{\text { leucogaster }}$

Sterna hirundo

S. dougallii

S. albifrons

S. maxima

S. $\overline{\text { fuscata }}$

$\bar{S}$. anaethetus

Annous stolidus

Puffinus iherminieri

Fregata magnificens

Larus atricilla

Gelochelidon nilotica

Pandion haliaetus

Falco peregrinus

F. colubarius

$\bar{F}$. sparverius

Buteo jamaicensis
Giant Toad

Antillean Frog

Whistling Frog

Common Coqui

Mute Frog

White-lipped frog

Cuban Treefrog 
Porzana carolina

Ral1us longirostris

Gallinula chloropus

Fulica americana

F. caribea

Haematopus palliatus

Charadrius semipalmatus

C. wilsonia

c. vociferus

Pluvialis (Squatarola) squatarola

Arenaria interpres

Capel1a (Gallinago $)$ gallinago

Actitis macularia

Tringa (Totanus) melanoleuca

T. (T.) flavipes

Cataptrophorus semipalmatus

Calidris (Erolia) melanotos

C. (E.) fusciollis

C. $\left(\bar{E}_{.}\right)$minutilla

C. (Ereunetes) pusilla

C. (E.) mauri

C. ( Crocethia $)$ alba

Limnodromus griseus

Micropalama himantopus

Himantopus mexicanus

Columba leucocephala

C. squamosa

Zenaida aurita

Columbina passerina

Geotrygon mystacea

Coccyzus minor

C. americanus

Caprimulgus carolinensis

Chondeiles minor

Megaceryle (Ceryle) alcyon

Sphyrapicus varius

Hirundo rustica

Mniotilta varia

Protonotaria citrea

Parula americana

Dendroica tigrina

D. petechia

D. coronata

D. virens

D. discolor

Seiurus aurocapillus

S. noveboracensis

S. motacil1a

Geothlypis trichas

Setophaga ruticilla

Icterus g. galbula
Sora

Clapper Rail

Common Gallinule

American Coot

Caribbean Coot

American Oystercatcher

Semipalmated Plover

Wilson's Plover

$\mathrm{Kill}$ deer

Black-bellied Plover

Ruddy Turnstone'

Common (Wilson's) Snipe

Spotted Sandpiper

Greater Yellowlegs

Lesser Yellowlegs

Willet

Pectoral Sandpiper

White-rumped Sandpiper

Least Sandpiper

Semipalmated Sandpiper

Western Sandpiper

Sanderling

Short-billed Dowitcher

Stilt Sandpiper

Black-necked Stilt

White-crowned Pigeon

Scaley-naped Pigeon

Zenaida Dove

Common Ground Dove

Bridled Quail Dove

Mangrove Cuckoo

Yellow-billed Cuckoo

Chuck-wi 11 's-widow

Common Nighthawk

Belthed Kingfi sher

Yellow-bellied Sapsucker

Barn Swallow

Black-and-white Warbler

Prothonotary Warbler

Northern Parula

Cape May Warbler

Yellow Warbler

Yellow-rumped Warbler

Blackpoll Warbler

Prairie Warbler

Ovenbird

Northern Waterthrush

Louisiana Waterthrush

Common Yellowthroat

American Redstart

Northern (Baltimore) Oriole 
I. icterus

Crotophage ani

Anthracothorax dominicus

Sericotes holosericeus

Orthorhyncus cristatus

Tyrannus dominicensis

Myiarchus stolidus

Elaenia martinica

Pronge dominicensis

Mimus polyglottos

Margarops fuscatus

Vireo alti Toquus

Coereba flaveola

Molothrus bonariensis

Tiaris bicolor
Troupial

Smooth-bill ed Ani

Ant illean Mango

Green-throated Carib

Antillean Crested Hummingbird

Gray Kingbird

Stolid Flycatcher

Caribbean Elaenia

Caribbean Martin

Mockingbird

Pearly-eyed Thrasher

Black-whiskered Vireo

Bananaquit

Gl ossy Cowbird

Black-faced Grassquit 
DISTRIBUTION: Comments have been requested from the following Federal, State, regional, and local agencies and interest groups:

\section{Federal Agencies}

Advisory Council on Historic Preservation

Department of Agriculture

Department of Commerce

Department of Defense

Department of Energy

Department of Health, Education \& Welfare

Department of Housing \& Urban Development

Department of the Interior

Department of Justice

Department of Labor

Department of Transportation

U.S. Coast Guard

Environmental Protection Agency

Federal Emergency Management

Federal Energy Regulatory Commission

Gencral Services Administration

Marine Mammal Commission

Nuclear Regulatory Commission

National Interest Groups

A.M.E.R.I.C.A.N.

AFL-CIO

American Association of Port Authorities

American Bar Association

American Bureau of Shipping

American Farm Bureau Federation

American Fisheries Society

Ame:ican Forest Institute

American Gas Association

American Hotel and Motel Association

American Industrial Development Council

American Institute of Architects

American Institute of Merchant Shipping

American Institute of Planners

American Littoral Society

American Mining Congress

American Oceanic Organization

American Petroleum Institute

American Shore and Beach Preservation Association

American Society of Civil Engineers

American Society of Landscape Architects, Inc.

American Society of Planning officials

American Water Resources Association

American Waterways Operators

Amoco Production Company

Ashland Oil, Inc.

Associated General Contractors of America 


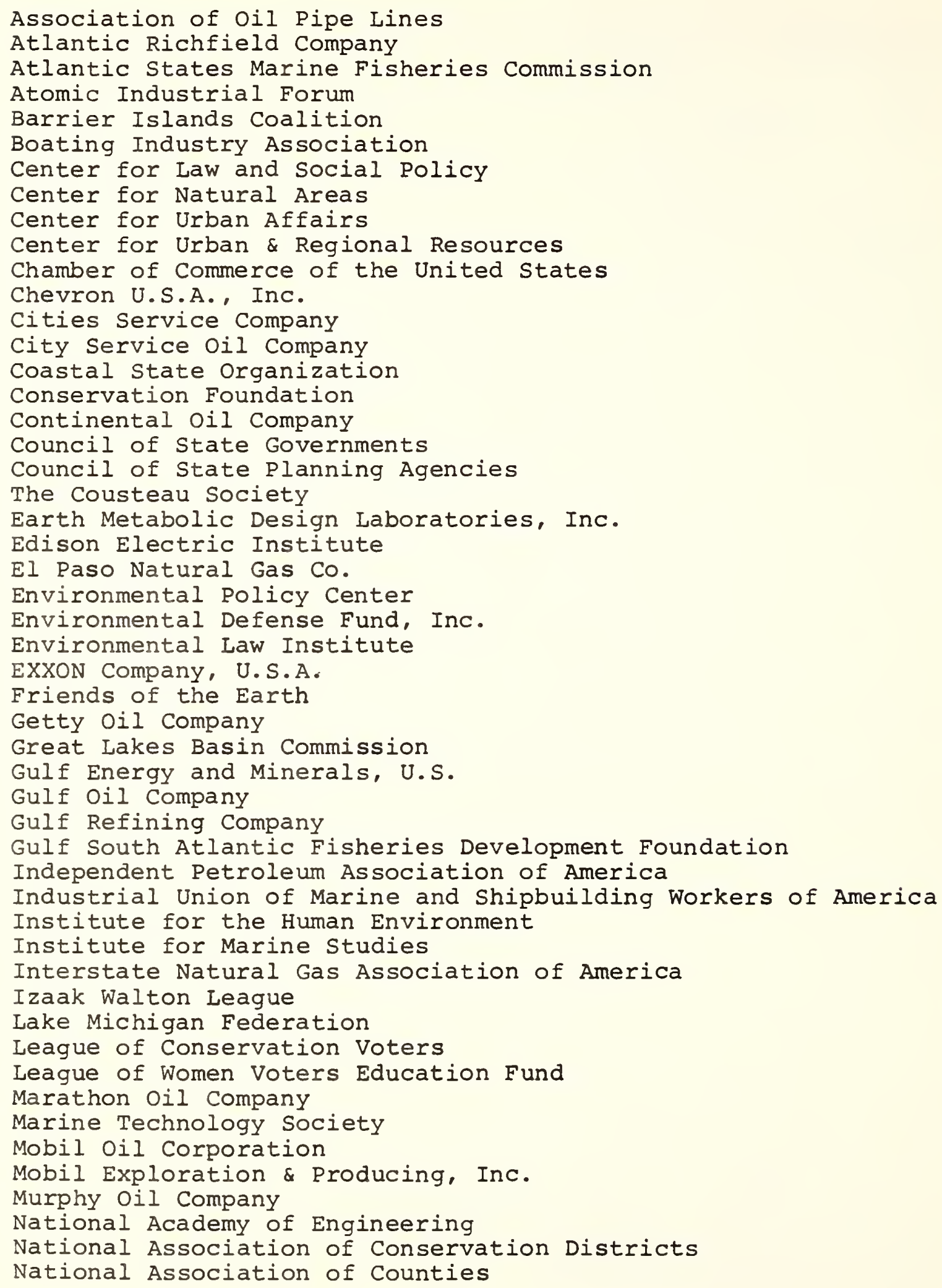


National Association of Dredging Contractors

National Association of Electric Companies

National Association of Engine and Boat Manufacturers

National Association of Home Builders

National Association of Realtors

National Association of Regional Councils

National Association of State Boating Law Administrators

National Association of State Park Directors

National Audubon Society

National Boating Federation

National Canners Association

National Coalition for Marine Conservation, Inc.

National Commission on Marine Policy

National Conference of State Legislators

National Environmental Development Association

National Farmers Union

National Federation of Fisherman

National Fisheries Institute

National Forest Products Association

National Governors Association

National League of Cities

National Ocean Industries Assocaition

National Parks and Conservation Association

National Petroleum Council

National Petroleum Refiners Assocaition

National Realty Committee

National Recreation and Park Association

National Research Council

National science Foundation

National Science Teachers Association

National Shrimp Congress

National Society of Professional Engineers

National Wildlife Federation

National Waterways Conference

Natural Gas Pipeline Company of America

Natural Resources Defense Council

The Nature Conservancy

Nautilus Press

New England River Basin Commission

North Atlantic Ports Association

Outboard Marine Corporation

Resources for the Future

Rice University Center for Community Design and Development

Shell Oil Company

Shellfish Institute of North America

Shipbuilders Council of America

Sierra club

Skelly oil Company

Society of Industrial Realtors

Society of Real Estate Appraisers

Soil Conservation Society of America

Southern California Gas Company 
National Interest Groups (Continued)

Sport Fishing Institute

Standard Oil Company of Ohio

Sun Company, Inc.

Tenneco Oil Company

Texaco, Inc.

Texas A \& M University

United Brotherhood of Carpenters \& Joiners of America

onion Oil Company of California

Urban Research and Development Association, Inc.

0. S. Conference of Mayors

J. S. Power Squadrons

Virgiria Marine Resources Commission

Water Pollution Control Federation

Water Transport Association

Wildife Management Institute

The Wildife Society

World Dredging Association

Virgin Islands Government Agencies

Administrators Office - St. Thomas, St. John, and St. Croix Budget Office

College of the Virgin Islands

Department of Commerce

Department of Conservation and Cultural Affairs

Department of Education

Department of Health

Department of Public Safety

Department of Public Works

Department of Social Welfare

Office of the Governor

Office of the Lieutenant Governor

Virgin Islands Legislature

Virgin Islands Planning Office

Local Interest Groups

Amateur Sports Organization

Boy Scouts of America

Carribbean Athropological Foundation, Inc.

Girl Scouts of Americal

Harmonic Lodge \#356 E.C.

Island Resources Foundation

Lions Club

Past Search

Rotary Club

St. Croix Landmarks Society

St. Croix Sports Club

St. John Yacht Club

St. Thomas Historical Society 


\section{Local Interest Groups (Continued)}

St. Thomas - St. John Swimming Association

St. Thomas Underwater Sports Association

St. Thomas Yacht Club

Tennants United for Fairness

Underwater Sports Club

Virgin Islands Game Fishing Club

Virgin Islands Historical Society

Virgin Islands League of Women Voters

Virgin Islands Conservation Society

Virgin Islands Sailing Association

Virgin Islands Yacht Club

Business Organizations

Chamber of Commerce

Fishermen Cooperative

Taxi Drivers Association - St. Thomas

Tropic Tours

United Tours, Inc.

Varlack Adventures 



PENN STATE UNIVERSIT

"IJUIIE UNIVERSITY LiBRARIES

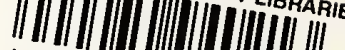

AODOO

940213 